\title{
Rhodium-Catalyzed Stitching Reaction: Convergent Synthesis of Quinoidal Fused Oligosiloles
}

\author{
Ryo Shintani,* Ryo Iino, and Kyoko Nozaki*
}

Department of Chemistry and Biotechnology, Graduate School of Engineering, The University of Tokyo, 7-3-1 Hongo, Bunkyo-ku, Tokyo 113-8656, Japan

\section{Supporting Information}

\section{General}

All air- and moisture-sensitive manipulations were carried out with standard Schlenk techniques or in a glove box under argon. NMR spectra were recorded on JEOL JNMECS400 or BRUKER Ascend500 spectrometers. Elemental analyses were performed by OneStop Sharing Facility Center for Future Drug Discoveries, Graduate School of Pharmaceutical Sciences, The University of Tokyo. High resolution mass spectra were recorded on JEOL AccuTOF LC-plus spectrometer. UV-VIS spectra were recorded on SHIMADZU UV-3150 spectrometer. Cyclic voltammograms were recorded on BAS ALS electrochemical analyzer 619Ep. X-ray crystallographic analysis was performed by RIGAKU VariMax Dual with Saturn724 diffractometer.

THF (Kanto Chemical; dehydrated), $\mathrm{Et}_{2} \mathrm{O}$ (Kanto Chemical; dehydrated), and toluene (Kanto Chemical; dehydrated) were purified by passing through neutral alumina columns under argon. Diisopropylamine (Wako Chemicals) and triethylamine (TCI) were distilled over $\mathrm{KOH}$ under vacuum. $\mathrm{CCl}_{4}$ (Wako Chemicals) was dried over $\mathrm{MgSO}_{4}$ and degassed by purging argon prior to use. 1,4-Dioxane (Wako Chemicals; dehydrated) was degassed by purging argon prior to use. 2,2-Dimethyl-1,3-propanediol (TCI), dichlorodiphenylsilane (TCI), chlorodiisopropylsilane (TCI), dichlorodiisopropylsilane (TCI), triisopropyl borate (TCI), trimethyl borate (TCI), ( \pm )-binap (TCI), 1,5-cyclooctadiene (TCI), 1propynylmagnesium bromide (Aldrich; $0.5 \mathrm{M}$ solution in THF), ethynylmagnesium bromide (Aldrich; 0.5 M solution in THF), $n$ BuLi (Kanto Chemical; 1.54-1.55 M solution in hexane), $\mathrm{Cs}_{2} \mathrm{CO}_{3}$ (Kanto Chemical), $\mathrm{Na}_{2} \mathrm{CO}_{3}$ (Wako Chemicals), 1,4-diazabicyclo[2.2.2] octane (TCI), $\mathrm{MgSO}_{4}$ (Kanto Chemical), MS4A (Nacalai Tesque; powder), and $\mathrm{PdCl}_{2}$ (Aldrich) were used as received. 2-(2-Bromophenylethynyl)phenylboronic acid, 1 (2-bromo-5chlorophenylethynyl)trimethylsilane, ${ }^{2}$ 1-bromo-4-chloro-2-iodobenzene, ${ }^{3}$ 1-bromo-2ethynylbenzene, ${ }^{4}$ and $[\mathrm{Rh}(\mathrm{OH})(\mathrm{cod})]_{2}^{5}$ were synthesized following the literature procedures.

\footnotetext{
${ }^{1}$ Iida, A.; Yamaguchi, S. J. Am. Chem. Soc. 2011, 133, 6952.

${ }^{2}$ Quan, Y.; Qiu, Z.; Xie, Z. J. Am. Chem. Soc. 2014, 136, 7599.

${ }^{3}$ Jensen, T.; Pedersen, H.; Bang-Andersen, B.; Madsen, R.; Jørgensen, M. Angew. Chem., Int. Ed. 2008, 47, 888.

${ }^{4}$ Alabugin, I. V.; Gilmore, K.; Patil, S.; Manoharan, M.; Kovalenko, S. V.; Clark, R. J.; Ghiviriga, I. J. Am. Chem. Soc. 2008, 130, 11535.

${ }^{5}$ Uson, R.; Oro, L. A.; Cabeza, J. A. Inorg. Synth. 1985, 23, 126.
} 


\section{Synthesis of Substrates}

\section{Representative Procedures for Substrates:}

2-(2-Bromophenylethynyl)phenylboronic acid neopentylglycol ester (1a)

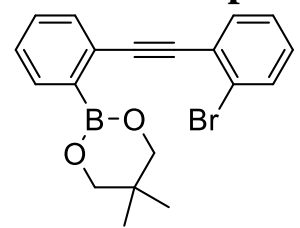

A mixture of 2-(2-bromophenylethynyl)phenylboronic acid (1.59 g, $5.28 \mathrm{mmol}), 2$,2dimethyl-1,3-propanediol (561 mg, $5.39 \mathrm{mmol})$, and MS4A $(1.05 \mathrm{~g})$ in toluene $(35 \mathrm{~mL})$ was refluxed for $1 \mathrm{~h}$. After cooled to room temperature, this was passed through a pad of $\mathrm{MgSO}_{4}$ with hexane and concentrated under vacuum. The residue was dissolved in pentane, filtered through a PTFE membrane (pore size: $0.20 \mu \mathrm{m}$ ), and concentrated under vacuum to afford compound 1 as a pale yellow viscous oil (1.93 g, $5.23 \mathrm{mmol}, 99 \%$ yield).

${ }^{1} \mathrm{H}$ NMR $\left(\mathrm{CDCl}_{3}\right): 7.76\left(\mathrm{dd},{ }^{3} J_{\mathrm{HH}}=7.4 \mathrm{~Hz}\right.$ and $\left.{ }^{4} J_{\mathrm{HH}}=1.0 \mathrm{~Hz}, 1 \mathrm{H}\right), 7.65-7.58(\mathrm{~m}, 2 \mathrm{H}), 7.55$ $\left(\mathrm{dd},{ }^{3} J_{\mathrm{HH}}=7.8 \mathrm{~Hz}\right.$ and $\left.{ }^{4} J_{\mathrm{HH}}=1.7 \mathrm{~Hz}, 1 \mathrm{H}\right), 7.38\left(\mathrm{td},{ }^{3} J_{\mathrm{HH}}=7.6 \mathrm{~Hz}\right.$ and $\left.{ }^{4} J_{\mathrm{HH}}=1.6 \mathrm{~Hz}, 1 \mathrm{H}\right), 7.32$ $\left(\mathrm{td},{ }^{3} J_{\mathrm{HH}}=7.6 \mathrm{~Hz}\right.$ and $\left.{ }^{4} J_{\mathrm{HH}}=1.6 \mathrm{~Hz}, 1 \mathrm{H}\right), 7.29\left(\mathrm{td},{ }^{3} J_{\mathrm{HH}}=7.7 \mathrm{~Hz}\right.$ and $\left.{ }^{4} J_{\mathrm{HH}}=1.3 \mathrm{~Hz}, 1 \mathrm{H}\right), 7.16$ $\left(\mathrm{ddd},{ }^{3} J_{\mathrm{HH}}=8.0\right.$ and $7.4 \mathrm{~Hz}$ and $\left.{ }^{4} J_{\mathrm{HH}}=1.7 \mathrm{~Hz}, 1 \mathrm{H}\right), 3.83(\mathrm{~s}, 4 \mathrm{H}), 1.06(\mathrm{~s}, 6 \mathrm{H}) .{ }^{13} \mathrm{C} \mathrm{NMR}$ $\left(\mathrm{CDCl}_{3}\right): \delta 134.4,133.6,133.2,132.5,129.9,129.1,127.8,127.0,126.9,126.3,125.4,95.6$, 89.4, 72.6, 32.0, 22.1. Anal. Calcd for $\mathrm{C}_{19} \mathrm{H}_{18} \mathrm{BBrO}_{2}$ : C, 61.83; H, 4.92. Found: C, 61.70; H, 5.07 .

\section{2-(2-Bromo-5-chlorophenylethynyl)-4-chlorophenylboronic acid neopentylglycol ester} (1b)

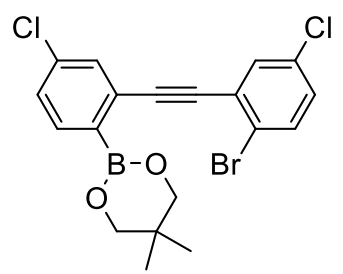

A mixture of (2-bromo-5-chlorophenylethynyl)trimethylsilane (1.72 $\mathrm{g}, 5.98 \mathrm{mmol})$ and $\mathrm{K}_{2} \mathrm{CO}_{3}(826 \mathrm{mg}, 5.98 \mathrm{mmol})$ in $\mathrm{CH}_{2} \mathrm{Cl}_{2}(10 \mathrm{~mL})$ and $\mathrm{MeOH}(10 \mathrm{~mL})$ was stirred for $1.5 \mathrm{~h}$ at room temperature. The reaction was quenched with $\mathrm{H}_{2} \mathrm{O}$ and extracted with $\mathrm{Et}_{2} \mathrm{O}$. The organic layer was washed with saturated $\mathrm{NaClaq}$, dried over $\mathrm{MgSO}_{4}$, filtered, and concentrated under vacuum. The residue was chromatographed on silica gel with hexane to afford 1-bromo-4-chloro-2-ethynylbenzene (CAS 1268870-34-3) as a white solid (1.10 g, $5.11 \mathrm{mmol} ; 85 \%$ yield).

${ }^{1} \mathrm{H}$ NMR $\left(\mathrm{CDCl}_{3}\right): 7.51\left(\mathrm{~d},{ }^{3} J_{\mathrm{HH}}=8.8 \mathrm{~Hz}, 1 \mathrm{H}\right), 7.50\left(\mathrm{~d},{ }^{4} J_{\mathrm{HH}}=2.3 \mathrm{~Hz}, 1 \mathrm{H}\right), 7.18\left(\mathrm{dd},{ }^{3} J_{\mathrm{HH}}\right.$ $=8.5 \mathrm{~Hz}$ and $\left.{ }^{4} J_{\mathrm{HH}}=2.6 \mathrm{~Hz}, 1 \mathrm{H}\right), 3.42(\mathrm{~s}, 1 \mathrm{H}) .{ }^{13} \mathrm{C} \mathrm{NMR}\left(\mathrm{CDCl}_{3}\right): \delta 133.8,133.6,133.2$, $130.4,125.9,123.7,83.2,80.9$.

A mixture of 1-bromo-4-chloro-2-ethynylbenzene (1.10 g, $5.11 \mathrm{mmol})$, 1-bromo-4chloro-2-iodobenzene (1.62 g, $5.10 \mathrm{mmol}), \mathrm{Pd}\left(\mathrm{PPh}_{3}\right)_{4}(236 \mathrm{mg}, 0.204 \mathrm{mmol}), \mathrm{CuI}(58.4 \mathrm{mg}$, $0.307 \mathrm{mmol})$ and $\mathrm{Et}_{3} \mathrm{~N}(2.14 \mathrm{~mL}, 15.4 \mathrm{mmol})$ in THF $(7 \mathrm{~mL})$ was stirred for $10 \mathrm{~h}$ at $40{ }^{\circ} \mathrm{C}$. The reaction was quenched with $\mathrm{H}_{2} \mathrm{O}$ and extracted with $\mathrm{CH}_{2} \mathrm{Cl}_{2}$. The organic layer was dried over $\mathrm{MgSO}_{4}$, filtered, and concentrated under vacuum. The residue was chromatographed on silica gel with hexane to afford 1,2-bis(2-bromo-5-chlorophenyl)ethyne as a white solid (1.93 g, $4.77 \mathrm{mmol}$; $93 \%$ yield).

${ }^{1} \mathrm{H} \mathrm{NMR}\left(\mathrm{CDCl}_{3}\right): 7.58\left(\mathrm{~d},{ }^{4} J_{\mathrm{HH}}=2.8 \mathrm{~Hz}, 2 \mathrm{H}\right), 7.55\left(\mathrm{~d},{ }^{3} J_{\mathrm{HH}}=8.6 \mathrm{~Hz}, 2 \mathrm{H}\right), 7.20\left(\mathrm{dd},{ }^{3} J_{\mathrm{HH}}\right.$ $=8.6 \mathrm{~Hz}$ and $\left.{ }^{4} J_{\mathrm{HH}}=2.5 \mathrm{~Hz}, 2 \mathrm{H}\right) \cdot{ }^{13} \mathrm{C} \mathrm{NMR}\left(\mathrm{CDCl}_{3}\right): \delta 133.8,133.34,133.29,130.4,126.3$, 


\section{7, 92.2.}

$n \operatorname{BuLi}(981 \mu \mathrm{L}, 1.57 \mathrm{mmol} ; 1.60 \mathrm{M}$ solution in hexane) was added to a solution of 1,2bis(2-bromo-5-chlorophenyl)ethyne $(636 \mathrm{mg}, 1.57 \mathrm{mmol})$ in THF (40 mL) slowly over 10 min at $-73{ }^{\circ} \mathrm{C}$, and the mixture was stirred for $40 \mathrm{~min}$ at -73 to $-71{ }^{\circ} \mathrm{C}$. Trimethyl borate $(526 \mu \mathrm{L}, 4.71 \mathrm{mmol})$ was then added to it and the mixture was stirred for $50 \mathrm{~min}$ at $-71{ }^{\circ} \mathrm{C}$ and for $2.5 \mathrm{~h}$ at room temperature. The reaction was quenched with $1 \mathrm{M}$ HClaq and extracted with $\mathrm{Et}_{2} \mathrm{O}$. The organic layer was washed with saturated $\mathrm{NaClaq}$, dried over $\mathrm{MgSO}_{4}$, filtered, and, concentrated under vacuum. The residue was chromatographed on silica gel with hexane $/ \mathrm{Et}_{2} \mathrm{O}=1 / 1$ to afford 2-(2-bromo-5-chlorophenylethynyl)-4-chlorophenylboronic acid as a white solid along with some inseparable impurity $(414 \mathrm{mg}$, ca. $1.12 \mathrm{mmol}$; ca. $71 \%$ yield). This was used for the next step without further purification.

${ }^{1} \mathrm{H} \mathrm{NMR}\left(\mathrm{CDCl}_{3}\right): 7.96\left(\mathrm{~d},{ }^{3} J_{\mathrm{HH}}=8.3 \mathrm{~Hz}, 1 \mathrm{H}\right), 7.62\left(\mathrm{~d},{ }^{4} J_{\mathrm{HH}}=2.0 \mathrm{~Hz}, 1 \mathrm{H}\right), 7.566\left(\mathrm{~d},{ }^{3} J_{\mathrm{HH}}\right.$ $=8.5 \mathrm{~Hz}, 1 \mathrm{H}), 7.565\left(\mathrm{~d},{ }^{4} J_{\mathrm{HH}}=2.5 \mathrm{~Hz}, 1 \mathrm{H}\right), 7.42\left(\mathrm{dd},{ }^{3} J_{\mathrm{HH}}=8.2 \mathrm{~Hz}\right.$ and $\left.{ }^{4} J_{\mathrm{HH}}=2.0 \mathrm{~Hz}, 1 \mathrm{H}\right)$, $7.24\left(\mathrm{dd},{ }^{3} J_{\mathrm{HH}}=8.6 \mathrm{~Hz}\right.$ and $\left.{ }^{4} J_{\mathrm{HH}}=2.4 \mathrm{~Hz}, 1 \mathrm{H}\right), 5.56(\mathrm{~s}, 2 \mathrm{H}) .{ }^{13} \mathrm{C} \mathrm{NMR}\left(\mathrm{CDCl}_{3}\right): \delta 137.41$, $137.38,133.9,133.8,133.4,133.0,130.8,129.5,127.7,125.9,123.3$, 94.0, 91.7. HRMS (ESI-TOF) calcd for $\mathrm{C}_{14} \mathrm{H}_{7} \mathrm{BBrCl}_{2} \mathrm{O}_{2}\left(\mathrm{M}-\mathrm{H}^{+}\right)$366.9105, found 366.9102 .

$\mathrm{MgSO}_{4}$ (404 mg, $3.36 \mathrm{mmol}$ ) was added to a solution of 2-(2-bromo-5chlorophenylethynyl)-4-chlorophenylboronic acid (414 $\mathrm{mg}$, ca. $1.12 \mathrm{mmol}$ ) and 2,2dimethyl-1,3-propanediol (119 mg, $1.14 \mathrm{mmol})$ in $\mathrm{CH}_{2} \mathrm{Cl}_{2}(20 \mathrm{~mL})$ and the mixture was stirred for $1 \mathrm{~h}$ at room temperature. The reaction mixture was passed through a pad of Celite with $\mathrm{CH}_{2} \mathrm{Cl}_{2}$ and concentrated under vacuum. The residue was purified by recrystallization from $\mathrm{CH}_{2} \mathrm{Cl}_{2}$ to afford compound $\mathbf{1 b}$ as a white solid $(223 \mathrm{mg}, 0.509 \mathrm{mmol} ; 32 \%$ yield over 2 steps).

${ }^{1} \mathrm{H} \mathrm{NMR}\left(\mathrm{CDCl}_{3}\right): 7.72\left(\mathrm{~d},{ }^{3} \mathrm{~J}_{\mathrm{HH}}=8.2 \mathrm{~Hz}, 1 \mathrm{H}\right), 7.58\left(\mathrm{~d},{ }^{4} J_{\mathrm{HH}}=2.0 \mathrm{~Hz}, 1 \mathrm{H}\right), 7.53\left(\mathrm{~d},{ }^{3} J_{\mathrm{HH}}=\right.$ $8.6 \mathrm{~Hz}, 1 \mathrm{H}), 7.51\left(\mathrm{~d},{ }^{4} J_{\mathrm{HH}}=2.6 \mathrm{~Hz}, 1 \mathrm{H}\right), 7.31\left(\mathrm{dd},{ }^{3} J_{\mathrm{HH}}=8.1 \mathrm{~Hz}\right.$ and $\left.{ }^{4} J_{\mathrm{HH}}=2.0 \mathrm{~Hz}, 1 \mathrm{H}\right), 7.16$ $\left(\mathrm{dd},{ }^{3} J_{\mathrm{HH}}=8.6 \mathrm{~Hz}\right.$ and $\left.{ }^{4} J_{\mathrm{HH}}=2.5 \mathrm{~Hz}, 1 \mathrm{H}\right), 3.82(\mathrm{~s}, 4 \mathrm{H}), 1.06(\mathrm{~s}, 6 \mathrm{H}) .{ }^{13} \mathrm{C} \mathrm{NMR}\left(\mathrm{CDCl}_{3}\right): \delta$ 136.1, 133.6, 133.3, 133.0, 132.8, 129.6, 128.4, 128.3, 127.4, 123.3, 95.4, 89.2, 72.6, 32.0, 22.1. Anal. Calcd for $\mathrm{C}_{19} \mathrm{H}_{16} \mathrm{BBrCl}_{2} \mathrm{O}_{2}$ : C, 52.11; H, 3.68. Found: C, 52.04; H, 3.85.

\section{Diphenyldi(1-propynyl)silane (2a)}

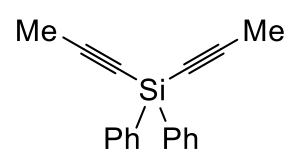

1-Propynylmagnesium bromide (22.0 mL, $11.0 \mathrm{mmol}$; $0.5 \mathrm{M}$ solution in THF) was added slowly to a solution of dichlorodiphenylsilane $(1.05 \mathrm{~mL}, 4.99 \mathrm{mmol})$ in THF (10 mL) over 15 min at $0{ }^{\circ} \mathrm{C}$, and the mixture was stirred for $8 \mathrm{~h}$ while gradually raising the temperature to room temperature. The reaction was quenched with saturated $\mathrm{NH}_{4} \mathrm{Claq}$ and extracted with $\mathrm{Et}_{2} \mathrm{O}$. The organic layer was washed with saturated $\mathrm{NaClaq}$, dried over $\mathrm{MgSO}_{4}$, filtered, and concentrated under vacuum. The residue was chromatographed on silica gel with hexane/EtOAc $=30 / 1$ to afford compound 2a (CAS 104584-84-1) as a white solid (1.23 g, $4.72 \mathrm{mmol}$; $95 \%$ yield).

${ }^{1} \mathrm{H} \mathrm{NMR}\left(\mathrm{CDCl}_{3}\right)$ : 7.77-7.71 (m, 4H), 7.44-7.34 (m, 6H), $2.01(\mathrm{~s}, 6 \mathrm{H}) .{ }^{13} \mathrm{C} \mathrm{NMR}\left(\mathrm{CDCl}_{3}\right)$ : $\delta 134.9,133.8,130.1,128.1,107.3,78.2,5.5$. 


\section{2-(((2-Bromophenylethynyl)diisopropylsilyl)ethynyl)phenylboronic acid neopentylglycol}

ester (4)

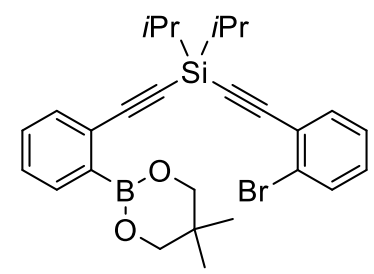

$n \operatorname{BuLi}(9.68 \mathrm{~mL}, 15.0 \mathrm{mmol} ; 1.55 \mathrm{M}$ solution in hexane) was added to a solution of diisopropylamine $(1.97 \mathrm{~mL}, 15.0 \mathrm{mmol})$ in $\mathrm{Et}_{2} \mathrm{O}(25 \mathrm{~mL})$ slowly over $7 \mathrm{~min}$ at $-74{ }^{\circ} \mathrm{C}$ and the mixture was stirred for $45 \mathrm{~min}$ while gradually raising the temperature to $0{ }^{\circ} \mathrm{C}$. This was cooled to $-74{ }^{\circ} \mathrm{C}$ again and 1-bromo-2-ethynylbenzene $(2.72 \mathrm{~g}, 15.0 \mathrm{mmol})$ was added with additional $\mathrm{Et}_{2} \mathrm{O}(5 \mathrm{~mL})$. The reaction mixture was stirred for $1 \mathrm{~h}$ at -74 to $-70{ }^{\circ} \mathrm{C}$ and dichlorodiisopropylsilane $(1.35 \mathrm{~mL}, 7.51 \mathrm{mmol})$ was added to it. The resulting mixture was stirred for $14 \mathrm{~h}$ while gradually raising the temperature to room temperature, and the reaction was quenched with $\mathrm{H}_{2} \mathrm{O}$. This was extracted with $\mathrm{Et}_{2} \mathrm{O}$, and the organic layer was washed with saturated $\mathrm{NaClaq}$, dried over $\mathrm{MgSO}_{4}$, filtered, and concentrated under vacuum. The residue was chromatographed on silica gel with hexane/EtOAc $=30 / 1$ to afford bis(2bromophenylethynyl)diisopropylsilane as a yellow solid $(3.47 \mathrm{~g}, 7.32 \mathrm{mmol}$; $98 \%$ yield).

${ }^{1} \mathrm{H} \mathrm{NMR}\left(\mathrm{CDCl}_{3}\right): 7.62-7.52(\mathrm{~m}, 4 \mathrm{H}), 7.26\left(\mathrm{t},{ }^{3} J_{\mathrm{HH}}=7.6 \mathrm{~Hz}, 2 \mathrm{H}\right), 7.18\left(\mathrm{t},{ }^{3} J_{\mathrm{HH}}=7.8 \mathrm{~Hz}\right.$, $2 \mathrm{H}), 1.33-1.16(\mathrm{~m}, 14 \mathrm{H}) .{ }^{13} \mathrm{C} \mathrm{NMR}\left(\mathrm{CDCl}_{3}\right): \delta 134.2,132.5,130.0,127.0,126.1,125.2$, $105.0,93.0,17.9,12.7$.

$n \operatorname{BuLi}(330 \mu \mathrm{L}, 0.508 \mathrm{mmol}$; $1.54 \mathrm{M}$ solution in hexane) was added to a solution of bis(2bromophenylethynyl)diisopropylsilane $(237 \mathrm{mg}, 0.500 \mathrm{mmol})$ and triisopropyl borate (120 $\mu \mathrm{L}, 0.523 \mathrm{mmol})$ in toluene $(0.70 \mathrm{~mL})$ and THF $(0.70 \mathrm{~mL})$ slowly over $13 \mathrm{~min}$ at $-77^{\circ} \mathrm{C}$, and the mixture was stirred for $1 \mathrm{~h}$ at -77 to $-71{ }^{\circ} \mathrm{C}$, then for 20 min while gradually raising the temperature to room temperature. The reaction was quenched with $1 \mathrm{M} \mathrm{HClaq}$ and this was

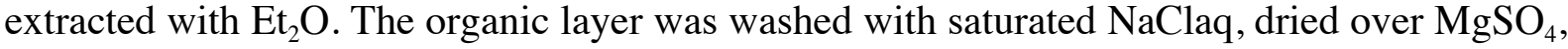
filtered, and concentrated under vacuum. The residue was chromatographed on silica gel with hexane $/ \mathrm{Et}_{2} \mathrm{O}=2 / 1$ and then further purified by $\mathrm{GPC}$ with $\mathrm{CHCl}_{3}$ to afford 2-(((2bromophenylethynyl)diisopropylsilyl)ethynyl)phenylboronic acid as a white solid (82.9 $\mathrm{mg}$, 0.189 mmol, $38 \%$ yield).

${ }^{1} \mathrm{H} \mathrm{NMR}\left(\mathrm{CDCl}_{3}\right)$ : 8.03-7.97 (m, 1H), 7.62-7.55 (m, 3H), 7.47-7.38 (m, 2H), 7.30-7.24 (m, $1 \mathrm{H}), 7.23-7.16(\mathrm{~m}, 1 \mathrm{H}), 5.80(\mathrm{bs}, 2 \mathrm{H}), 1.34-1.15(\mathrm{~m}, 14 \mathrm{H}) .{ }^{13} \mathrm{C} \mathrm{NMR}\left(\mathrm{CDCl}_{3}\right): \delta 135.8,134.3$, 133.2, 132.5, 130.8, 130.1 , 128.9, 127.0, 126.3, 126.1, 124.9, 108.6, 105.6, 92.6, 92.1 , 17.8, 12.5 .

2,2-Dimethyl-1,3-propanediol (20.1 $\mathrm{mg}, 0.193 \mathrm{mmol})$ and $\mathrm{MgSO}_{4}(68.2 \mathrm{mg}, 0.567 \mathrm{mmol})$ were added to a solution of 2-(((2-bromophenylethynyl)diisopropylsilyl)ethynyl)phenylboronic acid $(82.9 \mathrm{mg}, 0.189 \mathrm{mmol})$ in $\mathrm{CH}_{2} \mathrm{Cl}_{2}(3.0 \mathrm{~mL})$ and the mixture was stirred for $5 \mathrm{~h}$ at room temperature. The reaction mixture was passed through a pad of Celite with hexane and concentrated under vacuum. The residue was dissolved in pentane, filtered through a PTFE membrane (pore size: $0.20 \mu \mathrm{m}$ ), and concentrated under vacuum to afford compound 4 as a pale yellow viscous oil ( $95.6 \mathrm{mg}, 0.188 \mathrm{mmol} ; 100 \%$ yield).

${ }^{1} \mathrm{H}$ NMR $\left(\mathrm{CDCl}_{3}\right): 7.72-7.67(\mathrm{~m}, 1 \mathrm{H}), 7.60-7.52(\mathrm{~m}, 3 \mathrm{H}), 7.35-7.22(\mathrm{~m}, 3 \mathrm{H}), 7.17\left(\mathrm{td},{ }^{3} J_{\mathrm{HH}}\right.$ $=7.8 \mathrm{~Hz}$ and $\left.{ }^{4} J_{\mathrm{HH}}=1.8 \mathrm{~Hz}, 1 \mathrm{H}\right), 3.77(\mathrm{~s}, 4 \mathrm{H}), 1.29-1.12(\mathrm{~m}, 14 \mathrm{H}), 1.01(\mathrm{~s}, 6 \mathrm{H}) .{ }^{13} \mathrm{C}$ NMR $\left(\mathrm{CDCl}_{3}\right): \delta 134.2,134.1,133.9,132.5,129.8,129.7,127.9,127.0,126.8,125.9,125.4,108.5$, 104.4, 94.0, 88.6, 72.5, 31.9, 22.1, 17.9, 12.8. Anal. Calcd for $\mathrm{C}_{27} \mathrm{H}_{32} \mathrm{BBrO}_{2} \mathrm{Si}: \mathrm{C}, 63.92 ; \mathrm{H}$, 6.36. Found: C, 64.28; H, 6.61. 
1,2-Bis(diisopropyl(1-propynyl)silyl)ethyne (5)

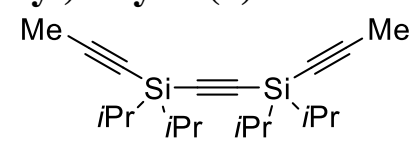

Ethynylmagnesium bromide (48.0 mL, $24.0 \mathrm{mmol}$; $0.5 \mathrm{M}$ solution in THF) was added to a solution of chlorodiisopropylsilane $(4.23 \mathrm{~mL}, 25.0 \mathrm{mmol})$ in THF $(25 \mathrm{~mL})$ slowly over 15 min at $0{ }^{\circ} \mathrm{C}$, and the mixture was stirred for $7 \mathrm{~h}$ while gradually raising the temperature to room temperature. The reaction was quenched with saturated $\mathrm{NH}_{4} \mathrm{Claq}$ and extracted with $\mathrm{Et}_{2} \mathrm{O}$. The organic layer was washed with saturated $\mathrm{NaClaq}$, dried over $\mathrm{MgSO}_{4}$, filtered, and concentrated under vacuum. The residue was chromatographed on silica gel with pentane to afford ethynyldiisopropylsilane (CAS 871951-30-3) as a colorless oil (1.46 g, $18.0 \mathrm{mmol}$; $72 \%$ yield).

${ }^{1} \mathrm{H}$ NMR $\left(\mathrm{CDCl}_{3}\right): 3.70(\mathrm{~s}, 1 \mathrm{H}), 2.43-2.35(\mathrm{~m}, 1 \mathrm{H}), 1.15-0.96(\mathrm{~m}, 14 \mathrm{H}) .{ }^{13} \mathrm{C}$ NMR $\left(\mathrm{CDCl}_{3}\right): \delta 95.9,84.0,18.5,18.2,10.7$.

$n \operatorname{BuLi}(6.10 \mathrm{~mL}, 9.45 \mathrm{mmol} ; 1.55 \mathrm{M}$ solution in hexane) was added to a solution of ethynyldiisopropylsilane $(1.46 \mathrm{~g}, 10.0 \mathrm{mmol})$ in THF $(50 \mathrm{~mL})$ slowly over $4 \mathrm{~min}$ at $-65^{\circ} \mathrm{C}$, and the mixture was stirred for $1 \mathrm{~h}$ at $-65^{\circ} \mathrm{C}$. Chlorodiisopropylsilane $(1.60 \mathrm{~mL}, 9.45 \mathrm{mmol})$ was then added to it and the resulting mixture was stirred for $30 \mathrm{~min}$ at $-65^{\circ} \mathrm{C}$ and for $12 \mathrm{~h}$ at room temperature. The reaction was quenched with $\mathrm{H}_{2} \mathrm{O}$ and extracted with $\mathrm{Et}_{2} \mathrm{O}$. The organic layer was washed with saturated $\mathrm{NaClaq}$, dried over $\mathrm{MgSO}_{4}$, filtered, and concentrated under vacuum. The residue was chromatographed on silica gel with hexane to afford 1,2-bis(diisopropylsilyl)ethyne (CAS 561068-52-8) as a colorless oil (2.23 g, 8.76 mmol, 93\% yield).

${ }^{1} \mathrm{H} \mathrm{NMR}\left(\mathrm{CDCl}_{3}\right): 3.70\left(\mathrm{t},{ }^{3} \mathrm{~J}_{\mathrm{HH}}=2.0 \mathrm{~Hz}, 2 \mathrm{H}\right), 1.14-0.95(\mathrm{~m}, 28 \mathrm{H}) .{ }^{13} \mathrm{C} \mathrm{NMR}\left(\mathrm{CDCl}_{3}\right): \delta$ $110.8,18.6,18.3,10.9$.

A solution of 1,2-bis(diisopropylsilyl)ethyne $(1.15 \mathrm{~g}, 4.52 \mathrm{mmol})$ in $\mathrm{CCl}_{4}(3.5 \mathrm{~mL})$ was added to $\mathrm{PdCl}_{2}(63.8 \mathrm{mg}, 0.360 \mathrm{mmol})$ slowly over $8 \mathrm{~min}$, and the mixture was stirred for $1 \mathrm{~h}$ at room temperature. The reaction mixture was passed through a pad of Celite with THF (12 $\mathrm{mL}$ ) and the volatiles were removed under vacuum. The residue was dissolved in THF (7 $\mathrm{mL}$ ) and the volatiles were removed under vacuum. This was repeated again to afford 1,2bis(chlorodiisopropylsilyl)ethyne as a pale yellow oil. This was dissolved in THF (9 mL) and 1-propynylmagnesium bromide $(18.0 \mathrm{~mL}, 9.00 \mathrm{mmol}$; $0.5 \mathrm{M}$ solution in THF) was added to it slowly over $10 \mathrm{~min}$ at $0{ }^{\circ} \mathrm{C}$. The resulting mixture was stirred for $16 \mathrm{~h}$ while gradually raising the temperature to room temperature, and the reaction was quenched with saturated $\mathrm{NH}_{4}$ Claq. After extraction with $\mathrm{Et}_{2} \mathrm{O}$, the organic layer was washed with saturated NaClaq, dried over $\mathrm{MgSO}_{4}$, filtered, and concentrated under vacuum. The residue was chromatographed on silica gel with hexane/EtOAc $=30 / 1$ to afford compound $\mathbf{5}$ as a white solid (1.46 g, $4.42 \mathrm{mmol}$; $98 \%$ yield).

${ }^{1} \mathrm{H}$ NMR $\left(\mathrm{CDCl}_{3}\right): 1.91(\mathrm{~s}, 6 \mathrm{H}) 1.13-0.88(\mathrm{~m}, 28 \mathrm{H}) .{ }^{13} \mathrm{C}$ NMR $\left(\mathrm{CDCl}_{3}\right): \delta$ 109.6, 105.1, 77.0, 17.7, 12.5, 5.1. Anal. Calcd for $\mathrm{C}_{20} \mathrm{H}_{34} \mathrm{Si}_{2}$ : C, 72.65; H, 10.36. Found: C, 72.60; H, 10.53.

\section{2-(((((2-Bromophenylethynyl)diisopropylsilyl)ethynyl)diisopropylsilyl)ethynyl)phenyl- boronic acid neopentylglycol ester (7)}

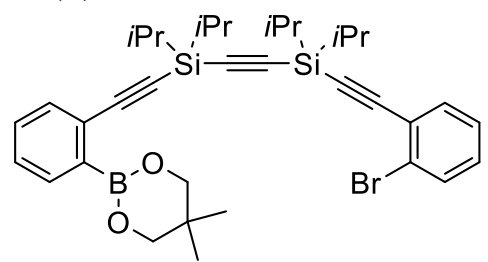

A solution of 1,2-bis(diisopropylsilyl)ethyne $(1.09 \mathrm{~g}, 4.28 \mathrm{mmol})$ in $\mathrm{CCl}_{4}(3.5 \mathrm{~mL})$ was 
added to $\mathrm{PdCl}_{2}(60.7 \mathrm{mg}, 0.342 \mathrm{mmol})$ slowly over $10 \mathrm{~min}$, and the mixture was stirred for $1.5 \mathrm{~h}$ at room temperature. The reaction mixture was passed through a pad of Celite with THF $(10 \mathrm{~mL})$ and the volatiles were removed under vacuum. The residue was dissolved in THF $(5 \mathrm{~mL})$ and the volatiles were removed under vacuum. This was repeated again to afford 1,2-bis(chlorodiisopropylsilyl)ethyne as a pale yellow oil. Separately, $n \operatorname{BuLi}(5.52 \mathrm{~mL}, 8.56$ mmol; $1.55 \mathrm{M}$ solution in hexane) was added to a solution of diisopropylamine $(1.20 \mathrm{~mL}$, $8.56 \mathrm{mmol})$ in $\mathrm{Et}_{2} \mathrm{O}(15 \mathrm{~mL})$ slowly over $4 \mathrm{~min}$ at $-75^{\circ} \mathrm{C}$, and the mixture was stirred for $1 \mathrm{~h}$ while gradually raising the temperature to $0{ }^{\circ} \mathrm{C}$. This was cooled to $-78{ }^{\circ} \mathrm{C}$ and 1-bromo-2ethynylbenzene $(1.55 \mathrm{~g}, 8.56 \mathrm{mmol})$ was added to it. The mixture was stirred for $1 \mathrm{~h}$ at -78 to $-75{ }^{\circ} \mathrm{C}$ and the cooling bath was removed. This was then added to a solution of 1,2bis(chlorodiisopropylsilyl)ethyne obtained above in $\mathrm{Et}_{2} \mathrm{O}(5 \mathrm{~mL})$ slowly over $7 \mathrm{~min}$ at $-75^{\circ} \mathrm{C}$ with the aid of additional $\mathrm{Et}_{2} \mathrm{O}(3 \mathrm{~mL})$. The resulting mixture was stirred for $1 \mathrm{~h}$ at -75 to $56{ }^{\circ} \mathrm{C}$ and for $17 \mathrm{~h}$ at room temperature. The reaction was quenched with saturated $\mathrm{H}_{2} \mathrm{O}$ and extracted with $\mathrm{Et}_{2} \mathrm{O}$. The organic layer was washed with saturated $\mathrm{NaClaq}$, dried over $\mathrm{MgSO}_{4}$, filtered, and concentrated under vacuum. The residue was chromatographed on silica gel with hexane/EtOAc $=50 / 1$ to afford 1,2-bis((2-bromophenylethynyl)diisopropylsilyl)ethyne as a yellow oil ( $2.02 \mathrm{~g}, 4.42 \mathrm{mmol}$; $77 \%$ yield).

${ }^{1} \mathrm{H} \mathrm{NMR}\left(\mathrm{CDCl}_{3}\right): 7.57\left(\mathrm{dd},{ }^{3} J_{\mathrm{HH}}=7.9 \mathrm{~Hz}\right.$ and $\left.{ }^{4} J_{\mathrm{HH}}=1.3 \mathrm{~Hz}, 2 \mathrm{H}\right), 7.54\left(\mathrm{dd},{ }^{3} J_{\mathrm{HH}}=7.7 \mathrm{~Hz}\right.$ and $\left.{ }^{4} J_{\mathrm{HH}}=1.7 \mathrm{~Hz}, 2 \mathrm{H}\right), 7.25\left(\mathrm{td},{ }^{3} J_{\mathrm{HH}}=7.6 \mathrm{~Hz}\right.$ and $\left.{ }^{4} J_{\mathrm{HH}}=1.2 \mathrm{~Hz}, 2 \mathrm{H}\right), 7.17\left(\mathrm{td},{ }^{3} J_{\mathrm{HH}}=7.7 \mathrm{~Hz}\right.$ and $\left.{ }^{4} J_{\mathrm{HH}}=1.7 \mathrm{~Hz}, 2 \mathrm{H}\right), 1.25-1.05(\mathrm{~m}, 28 \mathrm{H}) .{ }^{13} \mathrm{C} \mathrm{NMR}\left(\mathrm{CDCl}_{3}\right): \delta 134.2,132.5,129.9,127.0$, $126.1,125.2,109.7,104.8,93.0,17.82,17.80,12.5$.

$n \operatorname{BuLi}(6.43 \mathrm{~mL}, 9.96 \mathrm{mmol} ; 1.55 \mathrm{M}$ solution in hexane) was added to a solution of 1,2bis((2-bromophenylethynyl)diisopropylsilyl)ethyne $(6.10 \mathrm{~g}, 9.96 \mathrm{mmol})$ in THF $(55 \mathrm{~mL})$ slowly over $15 \mathrm{~min}$ at $-74{ }^{\circ} \mathrm{C}$, and the mixture was stirred for $1 \mathrm{~h}$ at -74 to $-72{ }^{\circ} \mathrm{C}$. Trimethyl borate $(3.34 \mathrm{~mL}, 29.9 \mathrm{mmol})$ was then added to it and the mixture was stirred for $1 \mathrm{~h}$ at -72 to $-66{ }^{\circ} \mathrm{C}$ and for $12 \mathrm{~h}$ at room temperature. The reaction was quenched with $\mathrm{H}_{2} \mathrm{O}$ and extracted with $\mathrm{Et}_{2} \mathrm{O}$. The organic layer was washed with saturated $\mathrm{NaClaq}$, dried over $\mathrm{MgSO}_{4}$, filtered, and concentrated under vacuum. The residue was chromatographed on silica gel with hexane/Et ${ }_{2} \mathrm{O}=6 / 1$, purified by GPC with $\mathrm{CHCl}_{3}$, and further passed through a pad of silica gel with hexane/ $\mathrm{Et}_{2} \mathrm{O}=6 / 1$ to afford 2-((((2-bromophenylethynyl)diisopropylsilyl)ethynyl)diisopropylsilyl)ethynyl)phenylboronic acid as a colorless oil $(2.01 \mathrm{~g}, 3.48 \mathrm{mmol}, 35 \%$ yield $)$.

${ }^{1} \mathrm{H}$ NMR $\left(\mathrm{CDCl}_{3}\right):$ 8.04-7.98 $(\mathrm{m}, 1 \mathrm{H}), 7.60-7.52(\mathrm{~m}, 3 \mathrm{H}), 7.46-7.38(\mathrm{~m}, 2 \mathrm{H}), 7.25\left(\mathrm{td},{ }^{3} J_{\mathrm{HH}}\right.$ $=7.6 \mathrm{~Hz}$ and $\left.{ }^{4} J_{\mathrm{HH}}=1.3 \mathrm{~Hz}, 1 \mathrm{H}\right), 7.17\left(\mathrm{ddd},{ }^{3} J_{\mathrm{HH}}=8.0\right.$ and $7.6 \mathrm{~Hz}$ and $\left.{ }^{4} J_{\mathrm{HH}}=1.8 \mathrm{~Hz}, 1 \mathrm{H}\right)$, $5.96(\mathrm{bs}, 1 \mathrm{H}), 1.26-1.09(\mathrm{~m}, 28 \mathrm{H}) .{ }^{13} \mathrm{C} \mathrm{NMR}\left(\mathrm{CDCl}_{3}\right): \delta 135.8,134.1,133.3,132.5,130.8$, $130.0,128.9$, 127.0, 126.3 , 126.0, 125.2 , 110.7, 108.7, 108.4, 104.9, 92.8, 92.6, 17.81, 17.76, $17.7,12.5,12.4$.

2,2-Dimethyl-1,3-propanediol (357 mg, $3.43 \mathrm{mmol}$ ) and MS4A (680 mg) were added to a solution of 2-((((2-bromophenylethynyl)diisopropylsilyl)ethynyl)diisopropylsilyl)ethynyl)phenylboronic acid $(1.98 \mathrm{~g}, 3.43 \mathrm{mmol})$ in toluene $(30 \mathrm{~mL})$ and the mixture was refluxed for $2 \mathrm{~h}$. After cooled to room temperature, this was passed through a pad of $\mathrm{MgSO}_{4}$ with hexane and concentrated under vacuum. This was dissolved in pentane, filtered through a PTFE membrane (pore size: $0.20 \mu \mathrm{m}$ ), and concentrated under vacuum to afford compound 7 as a yellow viscous oil ( $2.19 \mathrm{~g}, 3.39 \mathrm{mmol} ; 99 \%$ yield).

${ }^{1} \mathrm{H}$ NMR $\left(\mathrm{CDCl}_{3}\right): 7.70-7.65(\mathrm{~m}, 1 \mathrm{H}), 7.57\left(\mathrm{dd},{ }^{3} J_{\mathrm{HH}}=8.0 \mathrm{~Hz}\right.$ and $\left.{ }^{4} J_{\mathrm{HH}}=1.2 \mathrm{~Hz}, 1 \mathrm{H}\right)$, 7.55-7.50 (m, 2H), 7.34-7.27 (m, 2H), 7.24 (td, ${ }^{3} J_{\mathrm{HH}}=7.6 \mathrm{~Hz}$ and $\left.{ }^{4} J_{\mathrm{HH}}=1.2 \mathrm{~Hz}, 1 \mathrm{H}\right), 7.17(\mathrm{td}$, ${ }^{3} J_{\mathrm{HH}}=7.7 \mathrm{~Hz}$ and $\left.{ }^{4} J_{\mathrm{HH}}=1.8 \mathrm{~Hz}, 1 \mathrm{H}\right), 3.76(\mathrm{~s}, 4 \mathrm{H}), 1.23-1.04(\mathrm{~m}, 28 \mathrm{H}), 1.01(\mathrm{~s}, 6 \mathrm{H}) .{ }^{13} \mathrm{C}$ NMR $\left(\mathrm{CDCl}_{3}\right): \delta 134.2,133.9,132.5,129.9,129.7,127.9,127.0,126.9,126.0,125.3,110.6$, 108.7, 108.3, 104.7, 93.2, 88.6, 72.5, 31.9, 22.1, 17.84, 17.82, 12.7, 12.6. HRMS (ESI-TOF) calcd for $\mathrm{C}_{35} \mathrm{H}_{46} \mathrm{BBrO}_{2} \mathrm{Si}_{2} \mathrm{Na}\left(\mathrm{M}+\mathrm{Na}^{+}\right) 667.2210$, found 667.2185 . 


\section{Bis((diisopropyl(1-propynyl)silyl)ethynyl)diisopropylsilane (8)}<smiles>CC#C[Si](C#C[Si](C#CC)(C(C)C)C(C)(C)C(C)(C)C(C)(C)C)(C(C)C)C(C)(C)C</smiles>

$n$ BuLi (6.45 mL, $9.98 \mathrm{mmol} ; 1.55 \mathrm{M}$ solution in hexane) was added to a solution of ethynyldiisopropylsilane $(1.40 \mathrm{~g}, 9.98 \mathrm{mmol})$ in THF $(50 \mathrm{~mL})$ slowly over $4 \mathrm{~min}$ at $-75^{\circ} \mathrm{C}$ and the mixture was stirred for $1 \mathrm{~h}$ at -75 to $-65^{\circ} \mathrm{C}$. Dichlorodiisopropylsilane $(0.90 \mathrm{~mL}$, $5.01 \mathrm{mmol}$ ) was then added to it and the resulting mixture was stirred for $1.5 \mathrm{~h}$ at -65 to $10{ }^{\circ} \mathrm{C}$ and for $21 \mathrm{~h}$ at room temperature. The reaction was quenched with $\mathrm{H}_{2} \mathrm{O}$ and extracted with $\mathrm{Et}_{2} \mathrm{O}$. The organic layer was washed with saturated NaClaq, dried over $\mathrm{MgSO}_{4}$, filtered, and concentrated under vacuum. The residue was chromatographed on silica gel with hexane to afford bis((diisopropylsilyl)ethynyl)diisopropylsilane as a colorless oil (1.92 g, $4.89 \mathrm{mmol}$; $98 \%$ yield).

${ }^{1} \mathrm{H} \mathrm{NMR}\left(\mathrm{CDCl}_{3}\right): 3.69\left(\mathrm{t},{ }^{3} \mathrm{~J}_{\mathrm{HH}}=2.0 \mathrm{~Hz}, 2 \mathrm{H}\right), 1.18-0.93(\mathrm{~m}, 42 \mathrm{H}) .{ }^{13} \mathrm{C} \mathrm{NMR}\left(\mathrm{CDCl}_{3}\right): \delta$ $110.2,110.1,18.6,18.3,17.7,12.2,10.9$.

A solution of bis((diisopropylsilyl)ethynyl)diisopropylsilane $(1.65 \mathrm{~g}, 4.20 \mathrm{mmol})$ in $\mathrm{CCl}_{4}$ (4 mL) was added to $\mathrm{PdCl}_{2}(59.6 \mathrm{mg}, 0.336 \mathrm{mmol})$ slowly over $8 \mathrm{~min}$, and the mixture was stirred for $30 \mathrm{~min}$ at room temperature. The reaction mixture was passed through a pad of Celite with THF $(10 \mathrm{~mL})$ and the volatiles were removed under vacuum. The residue was dissolved in THF ( $8 \mathrm{~mL})$ and the volatiles were removed under vacuum. This was repeated again to afford bis((chlorodiisopropylsilyl)ethynyl)diisopropylsilane as a pale yellow oil. This was dissolved in THF $(10 \mathrm{~mL})$ and 1-propynylmagnesium bromide $(16.8 \mathrm{~mL}, 8.40$ mmol; $0.5 \mathrm{M}$ solution in THF) was added slowly over $8 \mathrm{~min}$ at $0{ }^{\circ} \mathrm{C}$. The resulting mixture was stirred for $16 \mathrm{~h}$ while gradually raising the temperature to room temperature, and the reaction was quenched with saturated $\mathrm{NH}_{4} \mathrm{Claq}$. After extraction with $\mathrm{Et}_{2} \mathrm{O}$, the organic layer was washed with saturated $\mathrm{NaClaq}$, dried over $\mathrm{MgSO}_{4}$, filtered, and concentrated under vacuum. The residue was chromatographed on silica gel with hexane/EtOAc $=50 / 1$ to afford compound 8 as a white solid (1.77 g, $3.77 \mathrm{mmol} ; 90 \%$ yield $)$.

${ }^{1} \mathrm{H}$ NMR $\left(\mathrm{CDCl}_{3}\right): 1.91(\mathrm{~s}, 6 \mathrm{H}) 1.13-1.05(\mathrm{~m}, 36 \mathrm{H}), 1.05-0.89(\mathrm{~m}, 6 \mathrm{H}) .{ }^{13} \mathrm{C} \mathrm{NMR}$ $\left(\mathrm{CDCl}_{3}\right): \delta 110.3,108.9,105.3,77.0,17.73,17.69,12.5,12.4,5.2$. Anal. Calcd for $\mathrm{C}_{28} \mathrm{H}_{48} \mathrm{Si}_{3}$ : C, 71.72; H, 10.32. Found: C, 71.62; H, 10.24.

\section{Analytical Data for Other Substrates: \\ Methyl(phenyl)di(1-propynyl)silane (2b)}

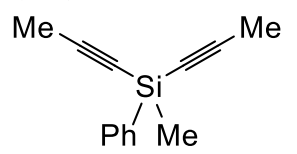

${ }^{1} \mathrm{H}$ NMR $\left(\mathrm{CDCl}_{3}\right)$ : 7.76-7.69 (m, 2H), 7.44-7.35 (m, 3H), $1.95(\mathrm{~s}, 6 \mathrm{H}), 0.51(\mathrm{~s}, 3 \mathrm{H}) .{ }^{13} \mathrm{C}$ NMR $\left(\mathrm{CDCl}_{3}\right): \delta 135.1,134.1,129.9,128.1,105.8,79.6,5.4,0.3$. Anal. Calcd for $\mathrm{C}_{13} \mathrm{H}_{14} \mathrm{Si}$ : C, 78.72; H, 7.12. Found: C, 78.82; H, 7.02.

\section{Diisopropyldi(1-propynyl)silane (2c)}

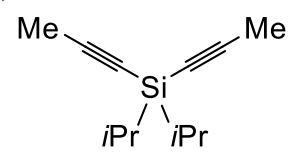

${ }^{1} \mathrm{H}$ NMR $\left(\mathrm{CDCl}_{3}\right): \delta 1.91(\mathrm{~s}, 6 \mathrm{H}), 1.12-1.00(\mathrm{~m}, 12 \mathrm{H}), 1.00-0.87(\mathrm{~m}, 2 \mathrm{H}) .{ }^{13} \mathrm{C}$ NMR $\left(\mathrm{CDCl}_{3}\right): \delta 104.8,77.7,17.7,12.5,5.2$. Anal. Calcd for $\mathrm{C}_{12} \mathrm{H}_{20} \mathrm{Si}: \mathrm{C}, 74.92 ; \mathrm{H}, 10.48$. Found: $\mathrm{C}, 74.85 ; \mathrm{H}, 10.47$. 
Diphenyldi(phenylethynyl)silane (2d) (CAS 18784-61-7)

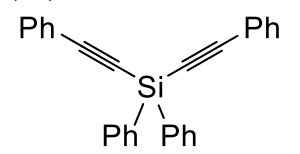

${ }^{1} \mathrm{H}$ NMR $\left(\mathrm{CDCl}_{3}\right): \delta$ 7.91-7.83 (m, 4H), 7.62-7.56 (m, 4H), 7.48-7.38 (m, 6H), 7.38-7.30 $(\mathrm{m}, 6 \mathrm{H}) .{ }^{13} \mathrm{C} \mathrm{NMR}\left(\mathrm{CDCl}_{3}\right): \delta 135.1,133.2,132.5,130.4,129.4,128.4,128.2,122.6,108.9$, 87.8.

(4-Methoxyphenylethynyl)diphenyl(1-propynyl)silane (2e)<smiles>CC#C[Si](C#Cc1ccc(OC)cc1)(c1ccccc1)c1ccccc1</smiles>

${ }^{1} \mathrm{H}$ NMR $\left(\mathrm{CDCl}_{3}\right)$ : 7.84-7.75 (m, 4H), 7.53-7.48 (m, 2H), 7.45-7.35 (m, 6H), 6.87-6.80 (m, $2 \mathrm{H}), 3.82(\mathrm{~s}, 3 \mathrm{H}), 2.03(\mathrm{~s}, 3 \mathrm{H}) .{ }^{13} \mathrm{C} \mathrm{NMR}\left(\mathrm{CDCl}_{3}\right): \delta 160.4,135.0,134.1,133.8,130.2,128.1$, 114.7, 114.0, 108.8, 107.6, 86.5, 78.0, 55.4, 5.5. HRMS (ESI-TOF) calcd for $\mathrm{C}_{24} \mathrm{H}_{20} \mathrm{OSiCs}$ $\left(\mathrm{M}+\mathrm{Cs}^{+}\right)$485.0338, found 485.0340.

(4-Bromophenylethynyl)diphenyl(1-propynyl)silane (2f)<smiles>CC#C[Si](C#Cc1ccc(Br)cc1)(c1ccccc1)c1ccccc1</smiles>

${ }^{1} \mathrm{H}$ NMR $\left(\mathrm{CDCl}_{3}\right): 7.83-7.73(\mathrm{~m}, 4 \mathrm{H}), 7.49-7.36(\mathrm{~m}, 10 \mathrm{H}), 2.04(\mathrm{~s}, 3 \mathrm{H}) .{ }^{13} \mathrm{C} \mathrm{NMR}$ $\left(\mathrm{CDCl}_{3}\right): \delta 134.9,133.9,133.2,131.7,130.4,128.2,123.7,121.6,108.0,107.1,89.7,77.6$, 5.5. Anal. Calcd for $\mathrm{C}_{23} \mathrm{H}_{17} \mathrm{BrSi}$ : C, 68.83; H, 4.27. Found: C, 68.67; H, 4.57.

\section{Catalytic Reactions}

\section{General Procedure for Table 2.}

1,5-Cyclooctadiene $(5.2 \mu \mathrm{L}, 42 \mu \mathrm{mol})$ and compound $2(0.100 \mathrm{mmol})$ were added with 1,4-dioxane $/ \mathrm{H}_{2} \mathrm{O}(0.50 \mathrm{~mL} ; 50 / 1)$ to a mixture of $[\mathrm{Rh}(\mathrm{OH})(\mathrm{cod})]_{2}(1.9 \mathrm{mg}, 8.3 \mu \mathrm{mol} \mathrm{Rh})$, $\mathrm{Cs}_{2} \mathrm{CO}_{3}$ (48.9 mg, $\left.0.150 \mathrm{mmol}\right)$, and compound $1(0.130 \mathrm{mmol})$ in 1,4-dioxane $/ \mathrm{H}_{2} \mathrm{O}(0.50$ $\mathrm{mL} ; 50 / 1)$. The reaction mixture was stirred for $20 \mathrm{~h}$ at $80{ }^{\circ} \mathrm{C}$ and this was directly passed through a pad of silica gel with $\mathrm{CH}_{2} \mathrm{Cl}_{2}$ and EtOAc. After removal of the solvent under vacuum, the residue was purified by silica gel preparative TLC to afford compound $\mathbf{3}$.

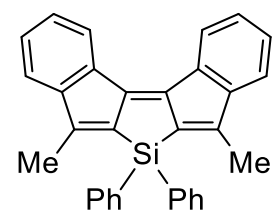

Table 2, Entry 1 (compound 3a). Before the purification of the crude material, it was dissolved in 1,4-dioxane $(2.0 \mathrm{~mL})$ and $\mathrm{H}_{2} \mathrm{O}(0.3 \mathrm{~mL})$, and $\mathrm{Cs}_{2} \mathrm{CO}_{3}(32.6 \mathrm{mg}, 0.100 \mathrm{mmol})$ was added. The mixture was stirred for $1 \mathrm{~h}$ at $80{ }^{\circ} \mathrm{C}$ to decompose the remaining compound $2 \mathbf{a}$ and this was passed through a pad of silica gel with $\mathrm{CH}_{2} \mathrm{Cl}_{2}$. After removal of the solvent under vacuum, the residue was dissolved in a minimal amount of $\mathrm{CH}_{2} \mathrm{Cl}_{2}$ and this was added 
dropwise to a stirring $\mathrm{MeOH}$. The precipitates that formed were collected by filtration with $\mathrm{MeOH}$ and dried under vacuum to give an orange solid. The filtrate was purified by silica gel preparative TLC with hexane/ $\mathrm{CH}_{2} \mathrm{Cl}_{2}=4 / 1$ and the solid thus obtained was washed with cold $\mathrm{MeOH}\left(-30^{\circ} \mathrm{C}\right)$ to give an orange solid. These solids were combined to afford compound $\mathbf{3 a}$. Orange solid. $79 \%$ yield.

${ }^{1} \mathrm{H}$ NMR $\left(\mathrm{CDCl}_{3}\right): 8.27-8.20(\mathrm{~m}, 2 \mathrm{H}), 7.76-7.68(\mathrm{~m}, 4 \mathrm{H}), 7.46-7.32(\mathrm{~m}, 12 \mathrm{H}), 2.36(\mathrm{~s}$, $6 \mathrm{H}) .{ }^{13} \mathrm{C}$ NMR $\left(\mathrm{CDCl}_{3}\right): \delta 150.1,150.0,146.9,142.2,135.7,135.0,133.5,130.0,128.9$, 128.3, 125.7, 125.2, 119.9, 14.8. HRMS (ESI-TOF) calcd for $\mathrm{C}_{32} \mathrm{H}_{24} \mathrm{SiCs}\left(\mathrm{M}+\mathrm{Cs}^{+}\right)$569.0702, found 569.0686 .

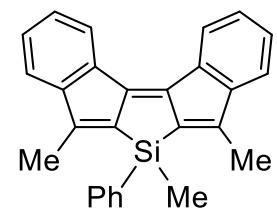

Table 2, Entry 2 (compound 3b). Hexane $/ \mathrm{CH}_{2} \mathrm{Cl}_{2}=4 / 1$ was used for silica gel preparative TLC. Orange solid. $70 \%$ yield.

${ }^{1} \mathrm{H} \mathrm{NMR}\left(\mathrm{CDCl}_{3}\right): 8.21\left(\mathrm{~d},{ }^{3} J_{\mathrm{HH}}=7.4 \mathrm{~Hz}, 2 \mathrm{H}\right), 7.73-7.60(\mathrm{~m}, 2 \mathrm{H}), 7.44-7.30(\mathrm{~m}, 9 \mathrm{H}), 2.32$ $(\mathrm{s}, 6 \mathrm{H}), 0.78(\mathrm{~s}, 3 \mathrm{H}) .{ }^{13} \mathrm{C} \mathrm{NMR}\left(\mathrm{CDCl}_{3}\right): \delta 150.1,149.8,146.1,143.5,135.6,134.8,134.5$, 129.7, 128.8, 128.2, 125.5, 125.1, 119.7, 14.5, -4.1. HRMS (ESI-TOF) calcd for $\mathrm{C}_{27} \mathrm{H}_{22} \mathrm{SiCs}$ $\left(\mathrm{M}+\mathrm{Cs}^{+}\right)$507.0545, found 507.0530.

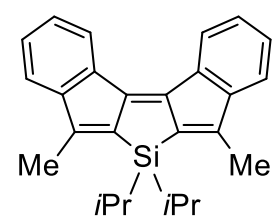

Table 2, Entry 3 (compound 3c). Hexane $/ \mathrm{CH}_{2} \mathrm{Cl}_{2}=6 / 1$ was used for silica gel preparative TLC. Orange solid. $58 \%$ yield.

${ }^{1} \mathrm{H}$ NMR $\left(\mathrm{CDCl}_{3}\right): \delta 8.20\left(\mathrm{~d},{ }^{3} \mathrm{~J}_{\mathrm{HH}}=7.2 \mathrm{~Hz}, 2 \mathrm{H}\right), 7.45-7.29(\mathrm{~m}, 6 \mathrm{H}), 2.36(\mathrm{~s}, 6 \mathrm{H}), 1.41$ (sept, $\left.{ }^{3} J_{\mathrm{HH}}=7.4 \mathrm{~Hz}, 2 \mathrm{H}\right), 1.09\left(\mathrm{~d},{ }^{3} J_{\mathrm{HH}}=7.3 \mathrm{~Hz}, 12 \mathrm{H}\right) \cdot{ }^{13} \mathrm{C} \mathrm{NMR}\left(\mathrm{CDCl}_{3}\right): \delta 150.7,150.3$, $145.3,142.5,135.1,128.6,125.2,124.9,119.4,19.1,15.3,11.9$. Anal. Calcd for $\mathrm{C}_{26} \mathrm{H}_{28} \mathrm{Si}$ : C, 84.72; H, 7.66. Found: C, 84.32; H, 7.80.

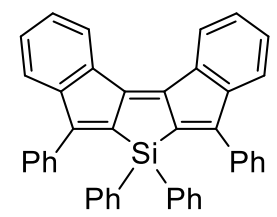

Table 2, Entry 4 (compound 3d). The crude material was purified by column chromatography on silica gel with hexane $/ \mathrm{CH}_{2} \mathrm{Cl}_{2}=8 / 1$. Impure fractions were further purified by silica gel preparative TLC with hexane $/ \mathrm{CH}_{2} \mathrm{Cl}_{2}=5 / 1$. The combined solid thus obtained was washed with cold hexane $\left(-30{ }^{\circ} \mathrm{C}\right)$ to afford compound 3d. Red solid. $61 \%$ yield.

${ }^{1} \mathrm{H}$ NMR $\left(\mathrm{CDCl}_{3}\right): \delta 8.48-8.34(\mathrm{~m}, 2 \mathrm{H}), 7.67-7.55(\mathrm{~m}, 2 \mathrm{H}), 7.55-7.37(\mathrm{~m}, 8 \mathrm{H}), 7.37-7.22$ $(\mathrm{m}, 12 \mathrm{H}), 7.18\left(\mathrm{t},{ }^{3} J_{\mathrm{HH}}=7.5 \mathrm{~Hz}, 4 \mathrm{H}\right) .{ }^{13} \mathrm{C} \mathrm{NMR}\left(\mathrm{CDCl}_{3}\right): \delta 152.4,150.8,148.8,144.3,137.1$, $135.9,135.6,133.8,129.9,129.2,128.7,128.6,128.2,128.1,126.1,125.9,121.8$. HRMS (ESI-TOF) calcd for $\mathrm{C}_{40} \mathrm{H}_{28} \mathrm{SiCs}\left(\mathrm{M}+\mathrm{Cs}^{+}\right)$693.1015, found 693.0990. 


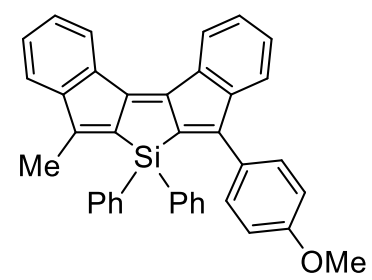

Table 2, Entry 5 (compound 3e). The crude material was purified by column chromatography on silica gel with hexane/EtOAc $=15 / 1$. Impure fractions were further purified by silica gel preparative TLC with hexane $/ \mathrm{CH}_{2} \mathrm{Cl}_{2}=3 / 1$. The solids thus obtained were combined to afford compound 3e. Red solid. $80 \%$ yield.

${ }^{1} \mathrm{H}$ NMR $\left(\mathrm{CDCl}_{3}\right)$ : 8.39-8.32 (m, 1H), 8.32-8.25 (m, 1H), 7.66-7.59 (m, 1H), 7.59-7.53 (m, $4 \mathrm{H}), 7.48-7.34(\mathrm{~m}, 9 \mathrm{H}), 7.30\left(\mathrm{t},{ }^{3} J_{\mathrm{HH}}=7.4 \mathrm{~Hz}, 4 \mathrm{H}\right), 6.84\left(\mathrm{~d},{ }^{3} J_{\mathrm{HH}}=8.7 \mathrm{~Hz}, 2 \mathrm{H}\right), 3.83(\mathrm{~s}, 3 \mathrm{H})$, $2.33(\mathrm{~s}, 3 \mathrm{H}) .{ }^{13} \mathrm{C} \mathrm{NMR}\left(\mathrm{CDCl}_{3}\right): \delta 159.6,151.5,150.4,150.2,149.7,148.4,147.4,142.7$, $142.4,135.8,135.6,134.9,133.6,130.0,129.9$, 129.6, 129.0, 128.7, 128.1, 125.9, 125.8, 125.5, 125.4, 121.6, 119.9, 114.0, 55.4, 14.7. HRMS (ESI-TOF) calcd for $\mathrm{C}_{38} \mathrm{H}_{28} \mathrm{OSiCs}$ $\left(\mathrm{M}+\mathrm{Cs}^{+}\right) 661.0964$, found 661.0949 .

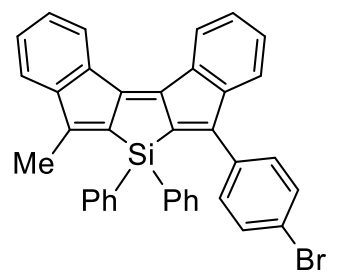

Table 2, Entry 6 (compound 3f). Hexane $/ \mathrm{CH}_{2} \mathrm{Cl}_{2}=5 / 1$ was used for silica gel preparative TLC and the solid thus obtained was washed with cold hexane $\left(-30{ }^{\circ} \mathrm{C}\right)$ to afford $3 f$. Red solid. $72 \%$ yield.

${ }^{1} \mathrm{H}$ NMR $\left(\mathrm{CDCl}_{3}\right): 8.35\left(\mathrm{~d},{ }^{3} J_{\mathrm{HH}}=7.8 \mathrm{~Hz}, 1 \mathrm{H}\right), 8.29\left(\mathrm{~d},{ }^{3} J_{\mathrm{HH}}=8.0 \mathrm{~Hz}, 1 \mathrm{H}\right), 7.62-7.50(\mathrm{~m}$, $5 \mathrm{H}), 7.49-7.37(\mathrm{~m}, 9 \mathrm{H}), 7.37-7.28(\mathrm{~m}, 6 \mathrm{H}), 2.32(\mathrm{~s}, 3 \mathrm{H}) .{ }^{13} \mathrm{C} \mathrm{NMR}\left(\mathrm{CDCl}_{3}\right): \delta 152.6,150.4$, $149.9,148.6,148.03,148.00,144.8,142.2$, 136.1 , 135.8, 135.4, 134.9, 133.2, 131.8, 130.3, 130.2, 129.4, 128.9, 128.3, 126.1, 126.0, 125.7, 125.6, 122.2, 121.3, 120.1, 14.7. HRMS (ESI-TOF) calcd for $\mathrm{C}_{37} \mathrm{H}_{25} \mathrm{BrSiCs}\left(\mathrm{M}+\mathrm{Cs}^{+}\right)$708.9963, found 708.9983.

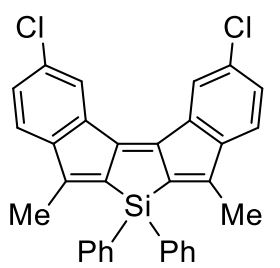

Table 2, Entry 7 (compound $\mathbf{3 g}$ ). The reaction was conducted with 1.0 equiv of $\mathbf{1 b}, 2.0$ equiv of $\mathbf{2 a}$, and 1.0 equiv of $\mathrm{Cs}_{2} \mathrm{CO}_{3}$ in the presence of $[\mathrm{Rh}(\mathrm{OH})(\mathrm{cod})]_{2}(30 \mathrm{~mol} \% \mathrm{Rh})$ and 1,5-cyclooctadiene (42 mol\%) in anhydrous 1,4-dioxane. Before the purification of the crude material, it was dissolved in 1,4-dioxane $(4.0 \mathrm{~mL})$ and $\mathrm{H}_{2} \mathrm{O}(0.6 \mathrm{~mL})$, and $\mathrm{Cs}_{2} \mathrm{CO}_{3}(65.2 \mathrm{mg}$, $0.200 \mathrm{mmol}$ ) was added. The mixture was stirred for $1 \mathrm{~h}$ at $80{ }^{\circ} \mathrm{C}$ to decompose the remaining compound $\mathbf{2 a}$ and this was passed through a pad of silica gel with $\mathrm{CH}_{2} \mathrm{Cl}_{2}$. After removal of the solvent under vacuum, the residue was dissolved in a minimal amount of $\mathrm{CH}_{2} \mathrm{Cl}_{2}$ and this was added dropwise to a stirring $\mathrm{MeOH}$. The precipitates that formed were collected by filtration with hexane and dried under vacuum to give an orange solid. The filtrate was purified by silica gel preparative TLC with hexane $/ \mathrm{CH}_{2} \mathrm{Cl}_{2}=4 / 1$ and the solid thus obtained was washed with hexane to give an orange solid. These solids were combined to afford compound 3g. Orange solid. $64 \%$ yield.

${ }^{1} \mathrm{H}$ NMR $\left(\mathrm{CDCl}_{3}\right): 8.06\left(\mathrm{~d},{ }^{4} J_{\mathrm{HH}}=1.8 \mathrm{~Hz}, 2 \mathrm{H}\right), 7.73-7.67(\mathrm{~m}, 4 \mathrm{H}), 7.47-7.42(\mathrm{~m}, 2 \mathrm{H})$, 
7.42-7.35 (m, 6H), $7.27\left(\mathrm{~d},{ }^{3} J_{\mathrm{HH}}=7.7 \mathrm{~Hz}, 2 \mathrm{H}\right), 2.33(\mathrm{~s}, 6 \mathrm{H}) \cdot{ }^{13} \mathrm{C}$ NMR $\left(\mathrm{CDCl}_{3}\right): \delta 149.7$, $148.5,147.0,142.8,136.3,135.7,133.0,132.2$, 130.3, 128.8, 128.4, 125.4, 120.6, 14.7. HRMS (ESI-TOF) calcd for $\mathrm{C}_{32} \mathrm{H}_{22} \mathrm{Cl}_{2} \mathrm{SiCs}\left(\mathrm{M}+\mathrm{Cs}^{+}\right)$636.9922, found 636.9933 .

\section{Procedure for Equatation 1.}

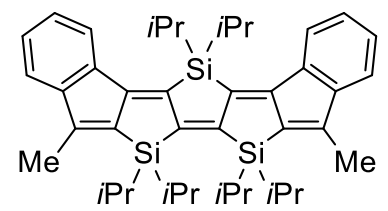

1,5-Cyclooctadiene $(5.2 \mu \mathrm{L}, 42 \mu \mathrm{mol})$ and compound $5(33.1 \mathrm{mg}, 0.100 \mathrm{mmol})$ were added with 1,4-dioxane $/ \mathrm{H}_{2} \mathrm{O}(0.50 \mathrm{~mL} ; 50 / 1)$ to a mixture of $[\mathrm{Rh}(\mathrm{OH})(\mathrm{cod})]_{2}(1.9 \mathrm{mg}, 8.3$ $\mu \mathrm{mol} \mathrm{Rh}), \mathrm{Cs}_{2} \mathrm{CO}_{3}(48.9 \mathrm{mg}, 0.150 \mathrm{mmol})$, and compound $4(66.0 \mathrm{mg}, 0.130 \mathrm{mmol})$ in $1,4-$ dioxane $/ \mathrm{H}_{2} \mathrm{O}(0.50 \mathrm{~mL} ; 50 / 1)$. The reaction mixture was stirred for $20 \mathrm{~h}$ at $80{ }^{\circ} \mathrm{C}$ and this was directly passed through a pad of silica gel with $\mathrm{CH}_{2} \mathrm{Cl}_{2}$ and EtOAc. After removal of the solvent under vacuum, the residue was chromatographed on silica gel with hexane $/ \mathrm{CH}_{2} \mathrm{Cl}_{2}=$ 30/1. Impure fractions were further purified by silica gel preparative TLC with hexane $/ \mathrm{CH}_{2} \mathrm{Cl}_{2}=5 / 1$. The combined solid thus obtained was washed with cold $\mathrm{MeOH}$ ($30{ }^{\circ} \mathrm{C}$ ) to afford compound 6 as an orange solid (33.5 mg, $51.9 \mu \mathrm{mol} ; 52 \%$ yield).

${ }^{1} \mathrm{H} \mathrm{NMR}\left(\mathrm{CDCl}_{3}\right): \delta 7.82\left(\mathrm{~d},{ }^{3} J_{\mathrm{HH}}=7.4 \mathrm{~Hz}, 2 \mathrm{H}\right), 7.38-7.27(\mathrm{~m}, 4 \mathrm{H}), 7.23-7.15(\mathrm{~m}, 2 \mathrm{H})$, $2.38(\mathrm{~s}, 6 \mathrm{H}), 1.85\left(\mathrm{sept},{ }^{3} J_{\mathrm{HH}}=7.4 \mathrm{~Hz}, 2 \mathrm{H}\right), 1.37\left(\mathrm{sept},{ }^{3} J_{\mathrm{HH}}=7.1 \mathrm{~Hz}, 4 \mathrm{H}\right), 1.27\left(\mathrm{~d},{ }^{3} J_{\mathrm{HH}}=7.0\right.$ $\mathrm{Hz}, 12 \mathrm{H}), 1.12\left(\mathrm{~d},{ }^{3} J_{\mathrm{HH}}=7.4 \mathrm{~Hz}, 12 \mathrm{H}\right), 0.88\left(\mathrm{~d},{ }^{3} J_{\mathrm{HH}}=7.1 \mathrm{~Hz}, 12 \mathrm{H}\right) .{ }^{13} \mathrm{C} \mathrm{NMR}\left(\mathrm{CDCl}_{3}\right): \delta$ 170.2, 159.4, 157.3, 149.6, 143.6, 138.2, 137.2, 127.6, 124.3, 122.1, 119.1, 19.6, 19.3, 15.7, 13.0, 12.7. HRMS (ESI-TOF) calcd for $\mathrm{C}_{42} \mathrm{H}_{56} \mathrm{Si}_{3} \mathrm{Cs}\left(\mathrm{M}+\mathrm{Cs}^{+}\right)$777.2744, found 777.2783.

\section{Procedure for Equatation 2.}

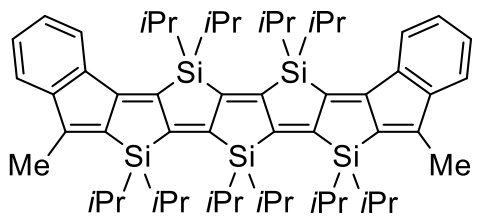

A solution of compound $7(83.9 \mathrm{mg}, 0.130 \mathrm{mmol})$ in 1,4-dioxane $(0.50 \mathrm{~mL})$ was added to a solution of $[\mathrm{Rh}(\mathrm{OH})(\mathrm{cod})]_{2}(22.8 \mathrm{mg}, 0.100 \mathrm{mmol} \mathrm{Rh}), 1,5$-cyclooctadiene $(5.2 \mu \mathrm{L}, 42$ $\mu \mathrm{mol})$, and compound $8(46.9 \mathrm{mg}, 0.100 \mathrm{mmol})$ in 1,4 -dioxane $(0.50 \mathrm{~mL})$. The reaction mixture was stirred for $20 \mathrm{~h}$ at $80{ }^{\circ} \mathrm{C}$ and this was directly passed through a pad of silica gel with $\mathrm{CH}_{2} \mathrm{Cl}_{2}$ and EtOAc. After removal of the solvent under vacuum, the residue was purified by silica gel preparative TLC with hexane $/ \mathrm{CH}_{2} \mathrm{Cl}_{2}=10 / 1$. The solid thus obtained was washed with cold hexane $\left(-30{ }^{\circ} \mathrm{C}\right)$ to afford compound 9 as a red solid $(25.4 \mathrm{mg}, 27.6 \mu \mathrm{mol}$; $28 \%$ yield).

${ }^{1} \mathrm{H} \mathrm{NMR}\left(\mathrm{CDCl}_{3}\right): \delta 7.87\left(\mathrm{~d},{ }^{3} J_{\mathrm{HH}}=7.6 \mathrm{~Hz}, 2 \mathrm{H}\right), 7.36-7.26(\mathrm{~m}, 4 \mathrm{H}), 7.18\left(\mathrm{t},{ }^{3} J_{\mathrm{HH}}=7.2 \mathrm{~Hz}\right.$, $2 \mathrm{H}), 2.39(\mathrm{~s}, 6 \mathrm{H}), 1.63\left(\mathrm{sept},{ }^{3} J_{\mathrm{HH}}=7.5 \mathrm{~Hz}, 4 \mathrm{H}\right), 1.50-1.33(\mathrm{~m}, 6 \mathrm{H}), 1.30\left(\mathrm{~d},{ }^{3} J_{\mathrm{HH}}=7.3 \mathrm{~Hz}\right.$, $12 \mathrm{H}), 1.28\left(\mathrm{~d},{ }^{3} J_{\mathrm{HH}}=7.6 \mathrm{~Hz}, 12 \mathrm{H}\right), 1.10\left(\mathrm{~d},{ }^{3} J_{\mathrm{HH}}=7.4 \mathrm{~Hz}, 12 \mathrm{H}\right), 0.98\left(\mathrm{~d},{ }^{3} J_{\mathrm{HH}}=7.3 \mathrm{~Hz}, 12 \mathrm{H}\right)$, $0.83\left(\mathrm{~d},{ }^{3} J_{\mathrm{HH}}=7.2 \mathrm{~Hz}, 12 \mathrm{H}\right) .{ }^{13} \mathrm{C} \mathrm{NMR}\left(\mathrm{CDCl}_{3}\right): \delta 167.8,167.1,166.3,159.0,156.8,149.6$, 143.0, 138.2, 137.4, 127.3, 124.0, 122.3, 118.9, 19.9, 19.8, 19.5, 19.0, 18.7, 15.9, 13.5, 13.3, 12.5. HRMS (ESI-TOF) calcd for $\mathrm{C}_{58} \mathrm{H}_{84} \mathrm{Si}_{5} \mathrm{Cs}\left(\mathrm{M}+\mathrm{Cs}^{+}\right) 1053.4474$, found 1053.4493 . 


\section{X-ray Crystal Structure of Compound 3c}

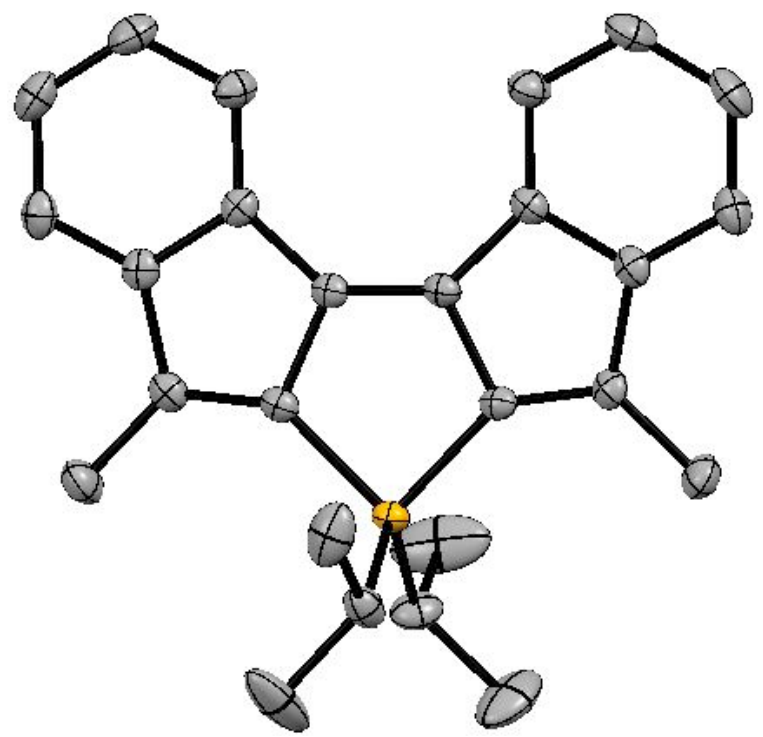

An orange pentane solution of compound 3c was prepared. Crystals suitable for X-ray analysis were obtained by cooling the solution at $-30{ }^{\circ} \mathrm{C}$. The crystal structure has been deposited at the Cambridge Crystallographic Data Centre (deposition number: CCDC 1443613). The data can be obtained free of charge via the Internet at www.ccdc.cam.ac.uk/conts/retrieving.html.

\section{Crystal Data and Structure Refinement.}

Empirical Formula

Formula Weight

Temperature

Wavelength

Crystal System

Space Group

Unit Cell Dimensions

Volume

Z Value

Calculated Density

Absorption coefficient

$\mathrm{F}(000)$
$\mathrm{C}_{26} \mathrm{H}_{28} \mathrm{Si}$

368.57

$93 \pm 2 \mathrm{~K}$

$0.71075 \AA$

Monoclinic

$\mathrm{P} 2 / \mathrm{n}$

$\begin{array}{ll}\mathrm{a}=8.4888(16) \AA & \alpha=90^{\circ} \\ \mathrm{b}=14.564(3) \AA & \beta=95.980(3)^{\circ} \\ \mathrm{c}=17.222(3) \AA & \gamma=90^{\circ}\end{array}$

2117.6(7) $\AA^{3}$

4

$1.156 \mathrm{~g} / \mathrm{cm}^{3}$

$0.118 \mathrm{~mm}^{-1}$

792 
Crystal size

Theta Range for Data Collection

Index Ranges

Reflections Collected

Independent Reflections

Completeness to Theta $=24.998^{\circ}$

Absorption Correction

Max. and Min. Transmission

Refinement Method

Data / Restraints / Parameters

Goodness-of-Fit on $\mathrm{F}^{2}$

Final R Indices [I $>2 \operatorname{sigma}(\mathrm{I})]$

R Indices (All Data)

Largest Diff. Peak and Hole
$0.620 \times 0.460 \times 0.200 \mathrm{~mm}$

$1.835-24.998^{\circ}$.

$-9 \leq \mathrm{h} \leq 10,-17 \leq \mathrm{k} \leq 17,-20 \leq 1 \leq 20$

27253

$3709[\mathrm{R}(\mathrm{int})=0.0343]$

$99.6 \%$

Semi-empirical from equivalents

1.000 and 0.896

Full-matrix least-squares on $\mathrm{F}^{2}$

3709 / 0 / 250

1.071

$\mathrm{R} 1=0.0401, \mathrm{wR} 2=0.0963$

$\mathrm{R} 1=0.0413, \mathrm{wR} 2=0.0977$

0.285 and $-0.280 \mathrm{e}^{-} / \AA^{3}$ 


\section{X-ray Crystal Structure of Compound 6}

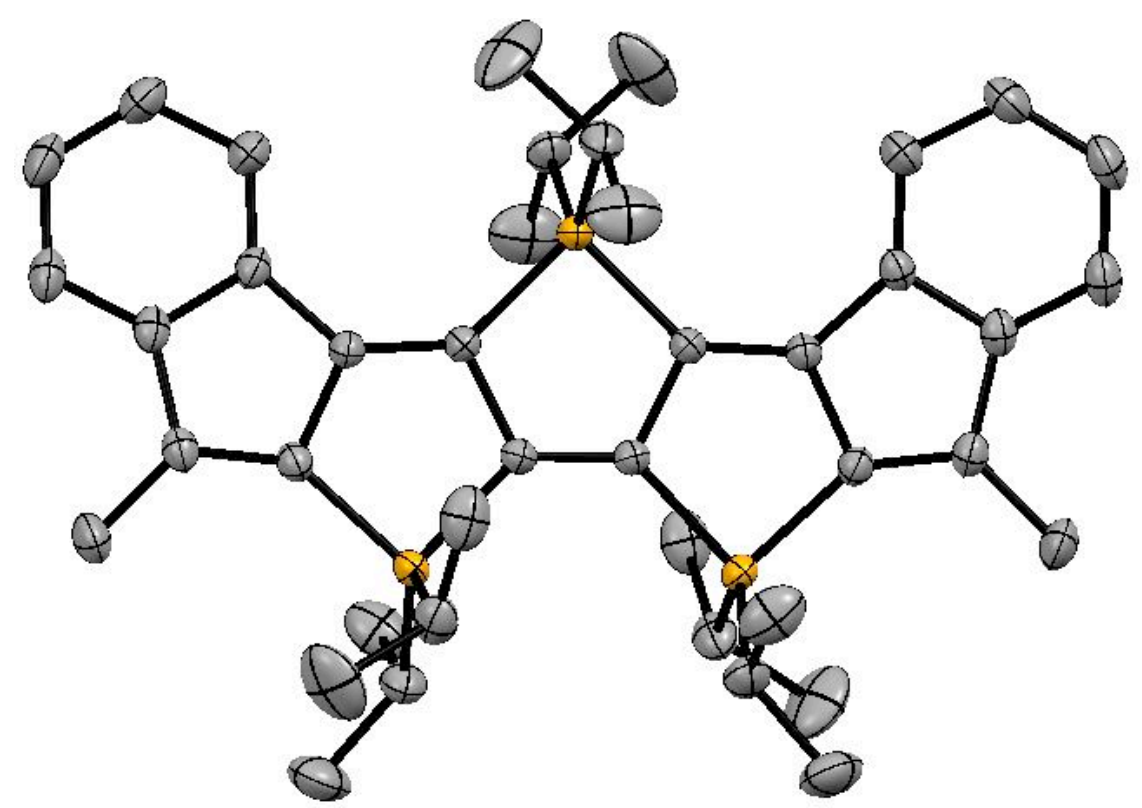

An orange $\mathrm{CH}_{2} \mathrm{Cl}_{2}$ solution of compound 6 was prepared. Crystals suitable for X-ray analysis were obtained by slow evaporation of the solvent at room temperature. The crystal structure has been deposited at the Cambridge Crystallographic Data Centre (deposition number: CCDC 1443614). The data can be obtained free of charge via the Internet at www.ccdc.cam.ac.uk/conts/retrieving.html.

\section{Crystal Data and Structure Refinement.}

Empirical Formula

Formula Weight

Temperature

Wavelength

Crystal System

Space Group

Unit Cell Dimensions

Volume

Z Value

Calculated Density

Absorption Coefficient

$$
\mathrm{C}_{42} \mathrm{H}_{56} \mathrm{Si}_{3}
$$

$173 \pm 2 \mathrm{~K}$

\section{$0.71075 \AA$}

Monoclinic

$\mathrm{C} 2 / \mathrm{c}$

$$
\begin{aligned}
& a=20.217(6) \AA \\
& \alpha=90^{\circ} \\
& \mathrm{b}=10.913(3) \AA \\
& \mathrm{c}=17.757(5) \AA \\
& \beta=102.872(4)^{\circ} \\
& \gamma=90^{\circ}
\end{aligned}
$$

$$
\text { 3819.2(19) } \AA^{3}
$$

4

\section{$1.122 \mathrm{~g} / \mathrm{cm}^{3}$}

$0.152 \mathrm{~mm}^{-1}$ 
$\mathrm{F}(000)$

Crystal Size

Theta Range for Data Collection

Index Ranges

Reflections Collected

Independent Reflections

Completeness to Theta $=25.242^{\circ}$

Absorption Correction

Max. and Min. Transmission

Refinement Method

Data / Restraints / Parameters

Goodness-of-Fit on $\mathrm{F}^{2}$

Final R Indices [I $>2 \operatorname{sigma}(\mathrm{I})]$

R Indices (All Data)

Largest Diff. Peak and Hole
1400

$0.450 \times 0.300 \times 0.100 \mathrm{~mm}^{3}$

$2.067-31.834^{\circ}$.

$-29 \leq \mathrm{h} \leq 29,-14 \leq \mathrm{k} \leq 16,-25 \leq 1 \leq 24$

35920

$6103[\mathrm{R}($ int $)=0.0496]$

$100.0 \%$

Semi-empirical from equivalents

1.000 and 0.916

Full-matrix least-squares on $\mathrm{F}^{2}$

$6103 / 0 / 211$

1.108

$\mathrm{R} 1=0.0570, \mathrm{wR} 2=0.1228$

$\mathrm{R} 1=0.0654, \mathrm{wR} 2=0.1283$

0.425 and $-0.287 \mathrm{e}^{-} / \AA^{3}$ 


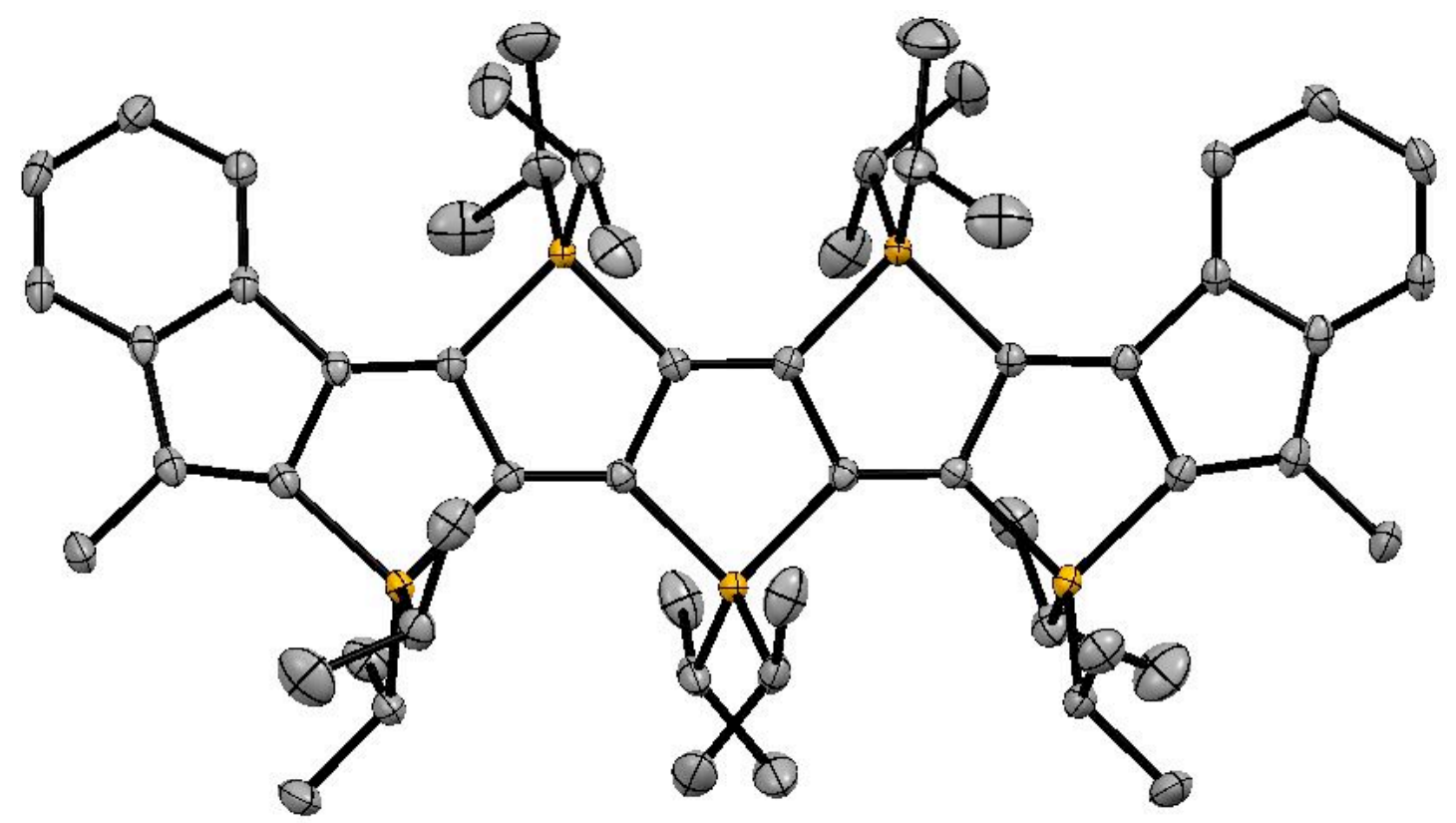

An orange $\mathrm{CH}_{2} \mathrm{Cl}_{2}$ solution of compound 9 was prepared. Crystals suitable for X-ray analysis were obtained by slow evaporation of the solvent at room temperature. The crystal structure has been deposited at the Cambridge Crystallographic Data Centre (deposition number: CCDC 1443615). The data can be obtained free of charge via the Internet at www.ccdc.cam.ac.uk/conts/retrieving.html.

\section{Crystal Data and Structure Refinement.}

Empirical Formula

Formula Weight

Temperature

Wavelength

Crystal System

Space Group

Unit Cell Dimensions

Volume

Z Value

Calculated Density

Absorption Coefficient
$\mathrm{C}_{58} \mathrm{H}_{84} \mathrm{Si}_{5}$

921.70

$93 \pm 2 \mathrm{~K}$

$0.71075 \AA$

Monoclinic

$\mathrm{C} 2 / \mathrm{c}$

$$
\begin{array}{ll}
\mathrm{a}=19.681(8) \AA & \alpha=90^{\circ} \\
\mathrm{b}=11.242(4) \AA & \beta=90.623(6)^{\circ} \\
\mathrm{c}=24.5359(10) \AA & \gamma=90^{\circ}
\end{array}
$$

$$
5428(3) \AA^{3}
$$

4

$1.128 \mathrm{~g} / \mathrm{cm}^{3}$

$0.167 \mathrm{~mm}^{-1}$ 
$\mathrm{F}(000)$

Crystal Size

Theta Range for Data Collection

Index Ranges

Reflections Collected

Independent Reflections

Completeness to Theta $=25.242^{\circ}$

Absorption Correction

Max. and Min. Transmission

Refinement Method

Data / Restraints / Parameters

Goodness-of-Fit on $\mathrm{F}^{2}$

Final R Indices [I $>2 \operatorname{sigma}(\mathrm{I})]$

R Indices (All Data)

Largest Diff. Peak and Hole
2008

$0.400 \times 0.350 \times 0.070 \mathrm{~mm}^{3}$

$2.070-26.499^{\circ}$.

$-24 \leq \mathrm{h} \leq 24,-14 \leq \mathrm{k} \leq 14,-30 \leq 1 \leq 30$

39948

$5625[\mathrm{R}(\mathrm{int})=0.0629]$

$99.9 \%$

Semi-empirical from equivalents

1.000 and 0.904

Full-matrix least-squares on $\mathrm{F}^{2}$

5625 / 0 / 296

1.119

$\mathrm{R} 1=0.0578, \mathrm{wR} 2=0.1245$

$\mathrm{R} 1=0.0654, \mathrm{wR} 2=0.1285$

0.735 and $-0.319 \mathrm{e}^{-} / \AA^{3}$ 
VII. UV-Vis Spectra of Compounds 3c, 6, and 9

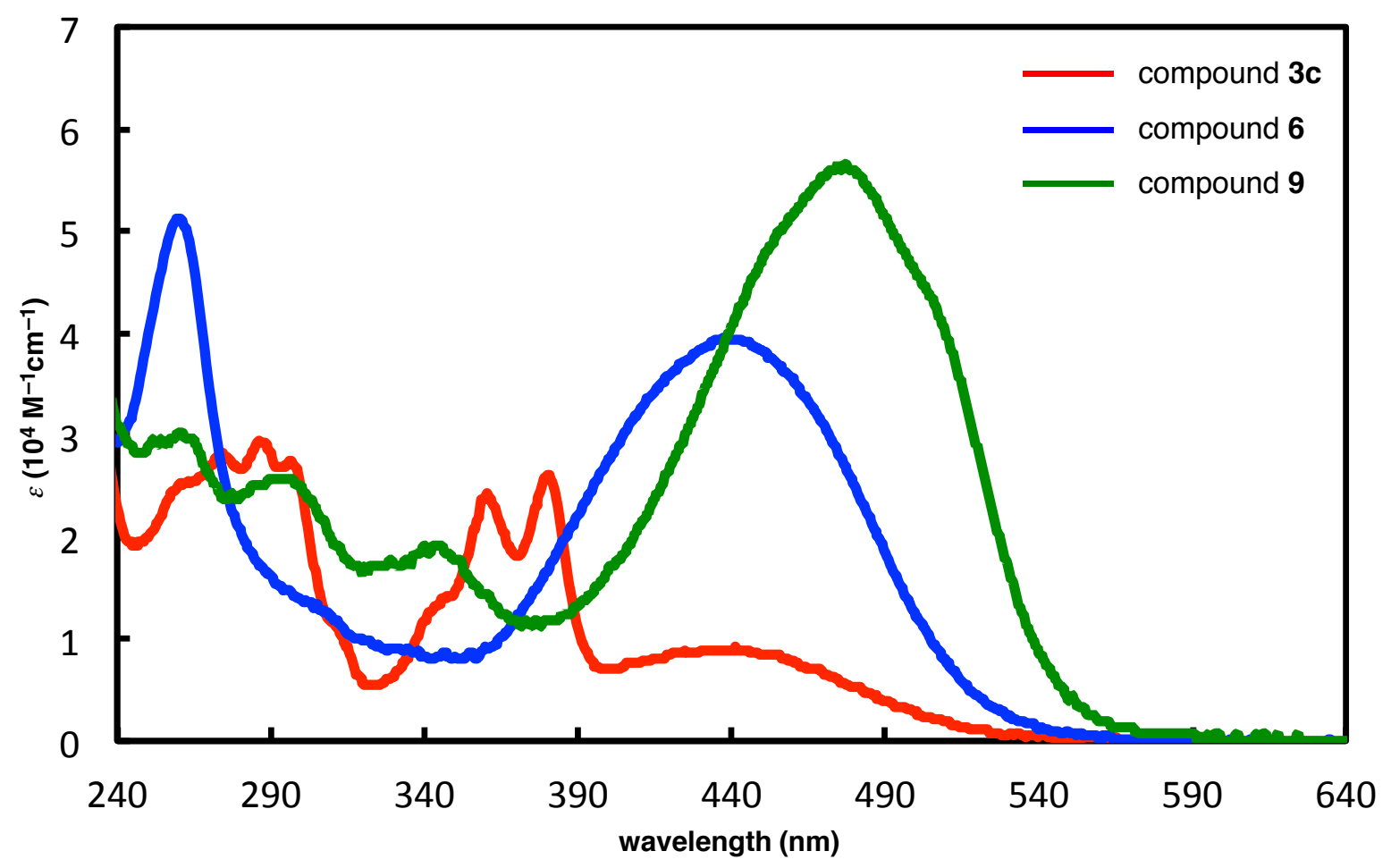

Figure S1. UV-vis spectra of compounds $3 \mathrm{c}$ (red line; at $3.8 \times 10^{-6} \mathrm{M}$ ), 6 (blue line; at $4.2 \mathrm{x}$ $10^{-6} \mathrm{M}$ ), and 9 (green line; at $1.5 \times 10^{-6} \mathrm{M}$ ) in $\mathrm{CH}_{2} \mathrm{Cl}_{2}$ at $25^{\circ} \mathrm{C}$.

Table S1. UV-vis absorption of compounds $\mathbf{3 c}, \mathbf{6}$, and $\mathbf{9}$.

\begin{tabular}{cl}
\hline compound & \multicolumn{1}{c}{$\lambda_{\max } / \mathrm{nm}\left(\varepsilon / 10^{4} \mathrm{M}^{-1} \mathrm{~cm}^{-1}\right)$} \\
\hline $3 \mathbf{c}$ & $274(2.8), 286(2.9), 297(2.7), 361(2.4), 380(2.6), 442(0.9)$ \\
$\mathbf{6}$ & $260(5.1), 438(4.0)$ \\
$\mathbf{9}$ & $261(3.0), 294(2.6), 345(1.9), 477(5.7)$ \\
\hline
\end{tabular}




\section{Cyclic Voltammograms of Compounds 3c, 6, and 9}

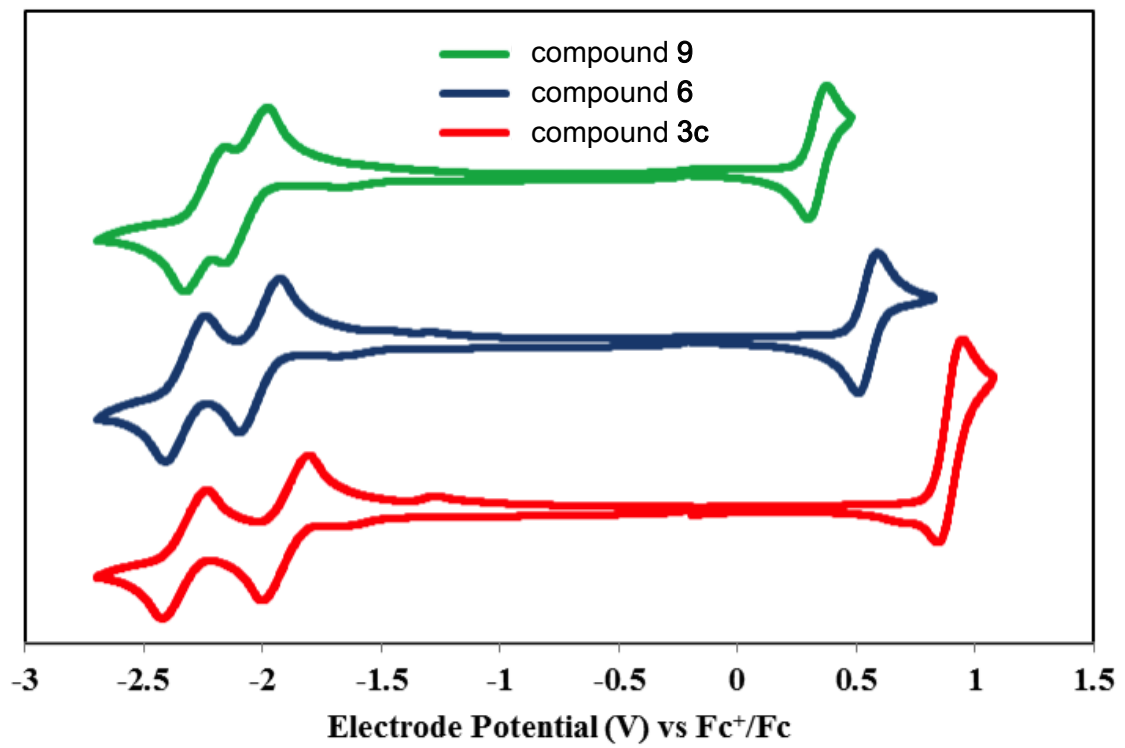

Figure S2. Cyclic voltammograms of compounds 3c, 6, and 9 at room temperature under argon containing $\mathrm{Ag} / \mathrm{Ag}^{+}$as the reference electrode, $\mathrm{Pt}$ as the working electrode, and $\mathrm{Pt}$ wire as the counter electrode. The oxidation potential was measured in $0.1 \mathrm{M} n \mathrm{Bu}_{4} \mathrm{NPF}_{6}$ solution in $\mathrm{CH}_{2} \mathrm{Cl}_{2}$ with a scan rate of $50 \mathrm{mV} / \mathrm{s}$. The reduction potential was measured in $0.1 \mathrm{M}$ $n \mathrm{Bu}_{4} \mathrm{NBF}_{4}$ solution in THF with a scan rate of $100 \mathrm{mV} / \mathrm{s}$. The potential was externally calibrated against the ferrocene/ferrocenium couple.

\section{Theoretical Calculations}

The computations were performed using workstation at Research Center for Computational Science, National Institutes of Natural Sciences, Okazaki, Japan. All the calculations were performed by using Gaussian 09 (revision D.1) program ${ }^{6}$, by B3LYP $\operatorname{method}^{7}$ with $6-31 \mathrm{G}(\mathrm{d})$ basis sets $^{8}$ for structure optimization, vibrational frequency, and timedependent calculations.

${ }^{6}$ Gaussian 09, Revision D.01, Frisch, M. J.; Trucks, G. W.; Schlegel, H. B.; Scuseria, G. E.; Robb, M. A.; Cheeseman, J. R.; Scalmani, G.; Barone, V.; Mennucci, B.; Petersson, G. A.; Nakatsuji, H.; Caricato, M.; Li, X.; Hratchian, H. P.; Izmaylov, A. F.; Bloino, J.; Zheng, G.; Sonnenberg, J. L.; Hada, M.; Ehara, M.; Toyota, K.; Fukuda, R.; Hasegawa, J.; Ishida, M.; Nakajima, T.; Honda, Y.; Kitao, O.; Nakai, H.; Vreven, T.; Montgomery, J. A., Jr.; Peralta, J. E.; Ogliaro, F.; Bearpark, M.; Heyd, J. J.; Brothers, E.; Kudin, K. N.; Staroverov, V. N.; Kobayashi, R.; Normand, J.; Raghavachari, K.; Rendell, A.; Burant, J. C.; Iyengar, S. S.; Tomasi, J.; Cossi, M.; Rega, N.; Millam, J. M.; Klene, M.; Knox, J. E.; Cross, J. B.; Bakken, V.; Adamo, C.; Jaramillo, J.; Gomperts, R.; Stratmann, R. E.; Yazyev, O.; Austin, A. J.; Cammi, R.; Pomelli, C.; Ochterski, J. W.; Martin, R. L.; Morokuma, K.; Zakrzewski, V. G.; Voth, G. A.; Salvador, P.; Dannenberg, J. J.; Dapprich, S.; Daniels, A. D.; Farkas, Ö.; Foresman, J. B.; Ortiz, J. V.; Cioslowski, J.; Fox, D. J. Gaussian, Inc., Wallingford CT, 2009. ${ }^{7}$ (a) Lee, C.; Yang, W.; Parr, R. G. Phys. Rev. B 1988, 37, 785. (b) Becke, A. D. J. Chem. Phys. 1993, 98, 5648.

${ }^{8}$ (a) Ditchfield, R.; Hehre, W. J.; Pople, J. A. J. Chem. Phys. 1971, 54, 724. (b) Hehre, W. J.; Ditchfield, R.; Pople, J. A. J. Chem. Phys. 1972, 56, 2257. 


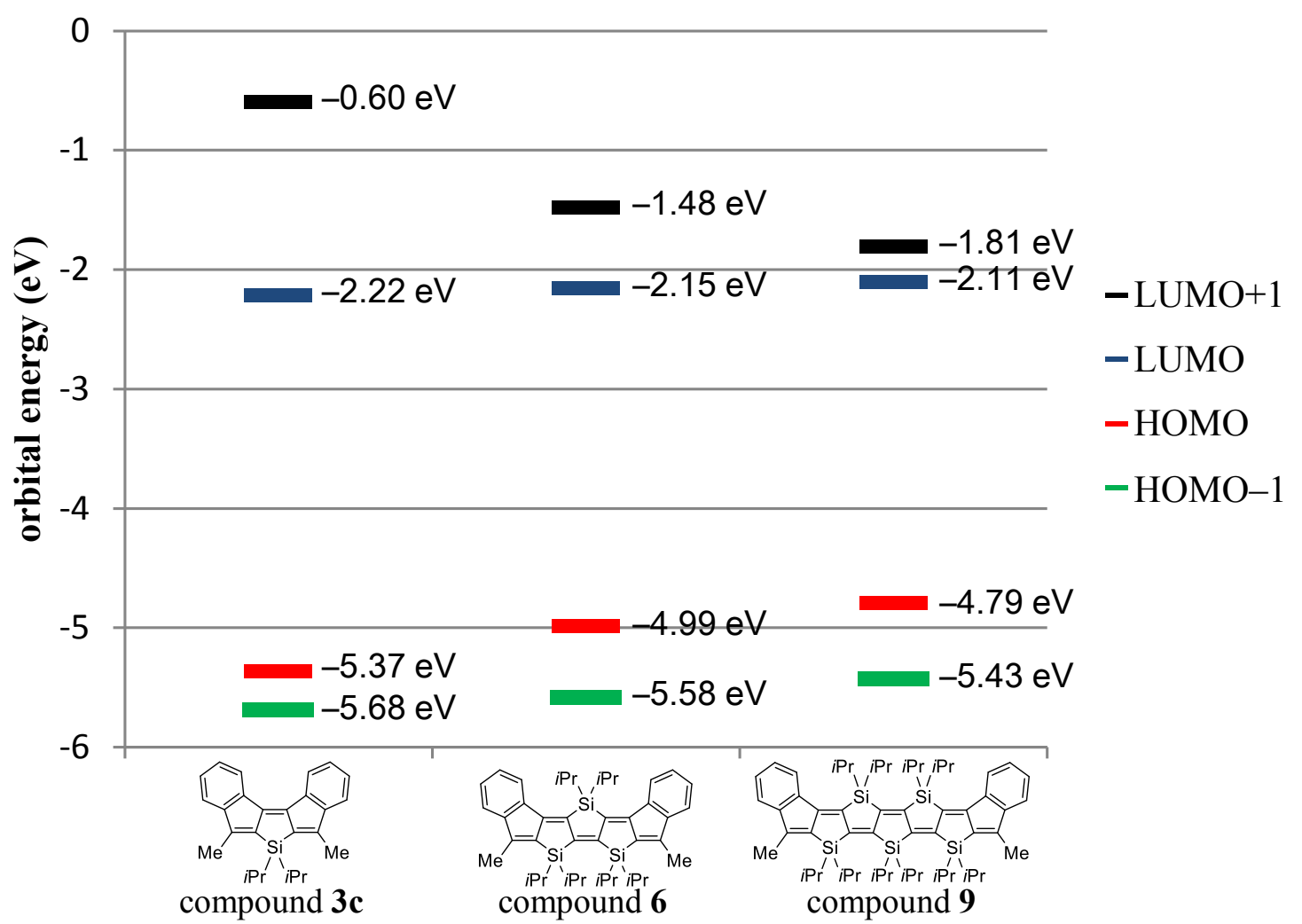

Figure S3. Molecular orbital energy diagrams of compounds $3 \mathbf{c}, \mathbf{6}$, and $\mathbf{9}$ calculated at the B3LYP/6-31G(d) level of theory.

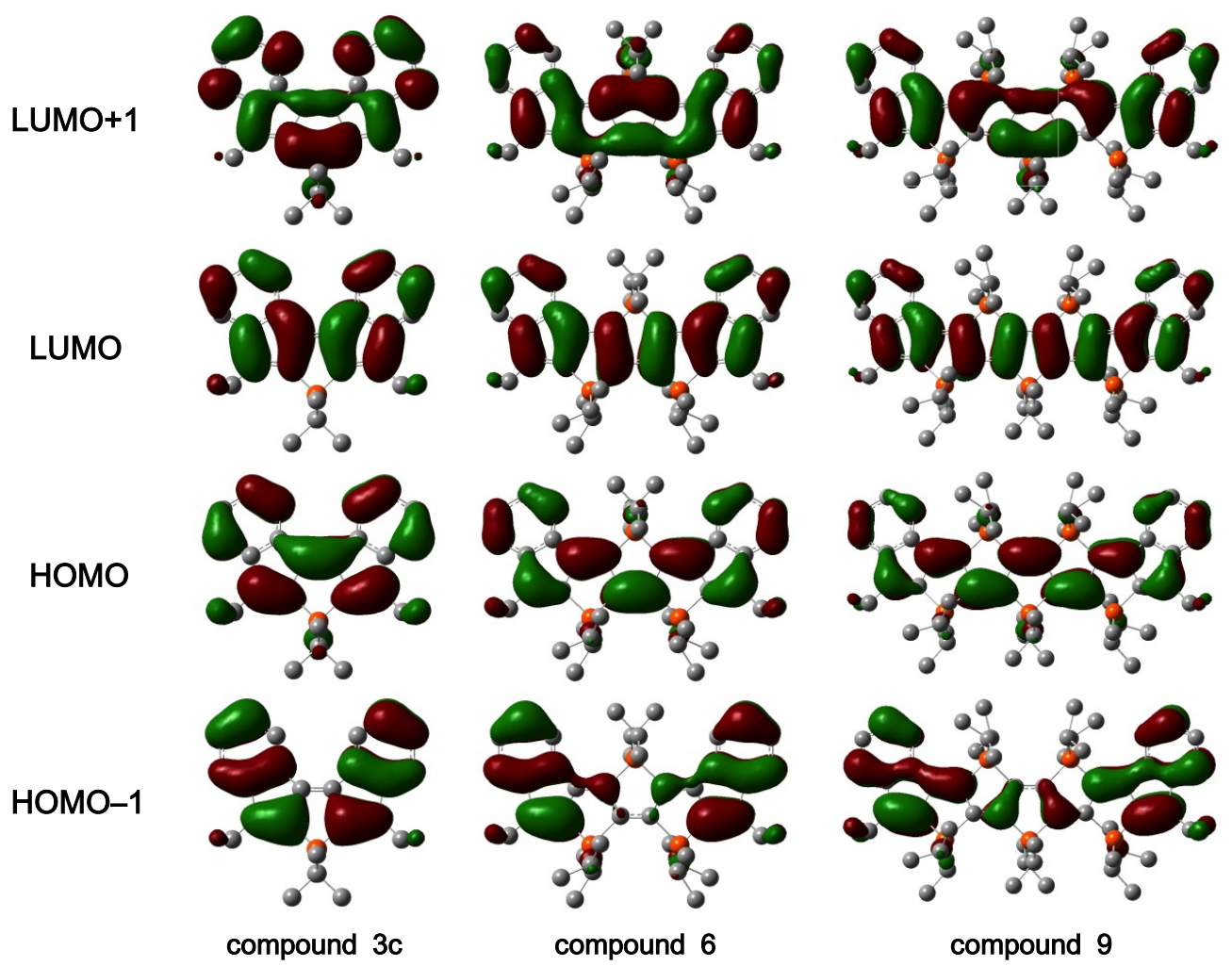

Figure S4. Molecular orbitals from HOMO-1 to LUMO+1 of compounds $\mathbf{3 c}, \mathbf{6}$, and 9 calculated at the B3LYP/6-31G(d) level of theory. 


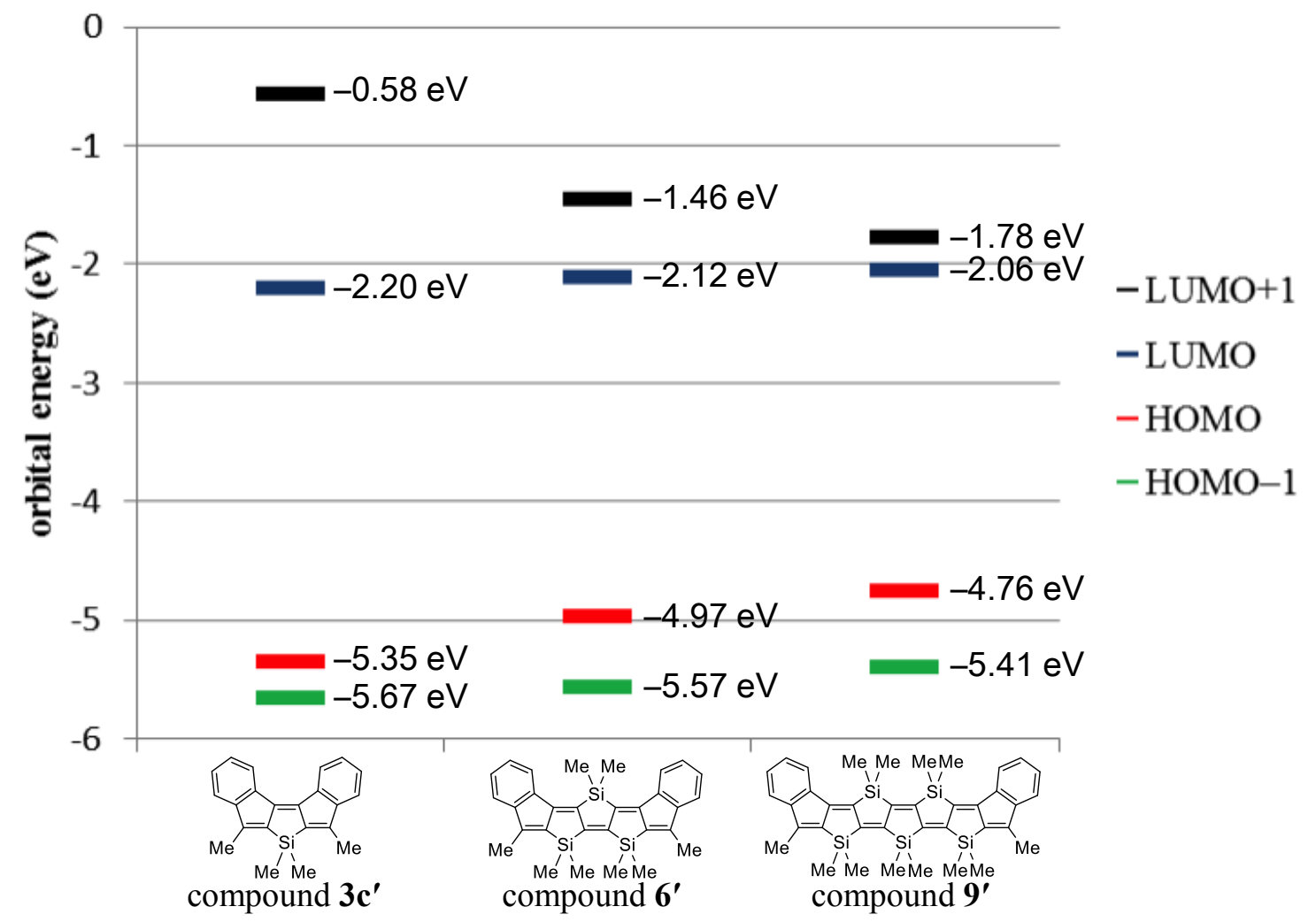

Figure S5. Molecular orbital energy diagrams of dimethylsilyl variants $3 \mathbf{c}^{\prime}, \mathbf{6}^{\prime}$, and 9' calculated at the B3LYP/6-31G(d) level of theory.

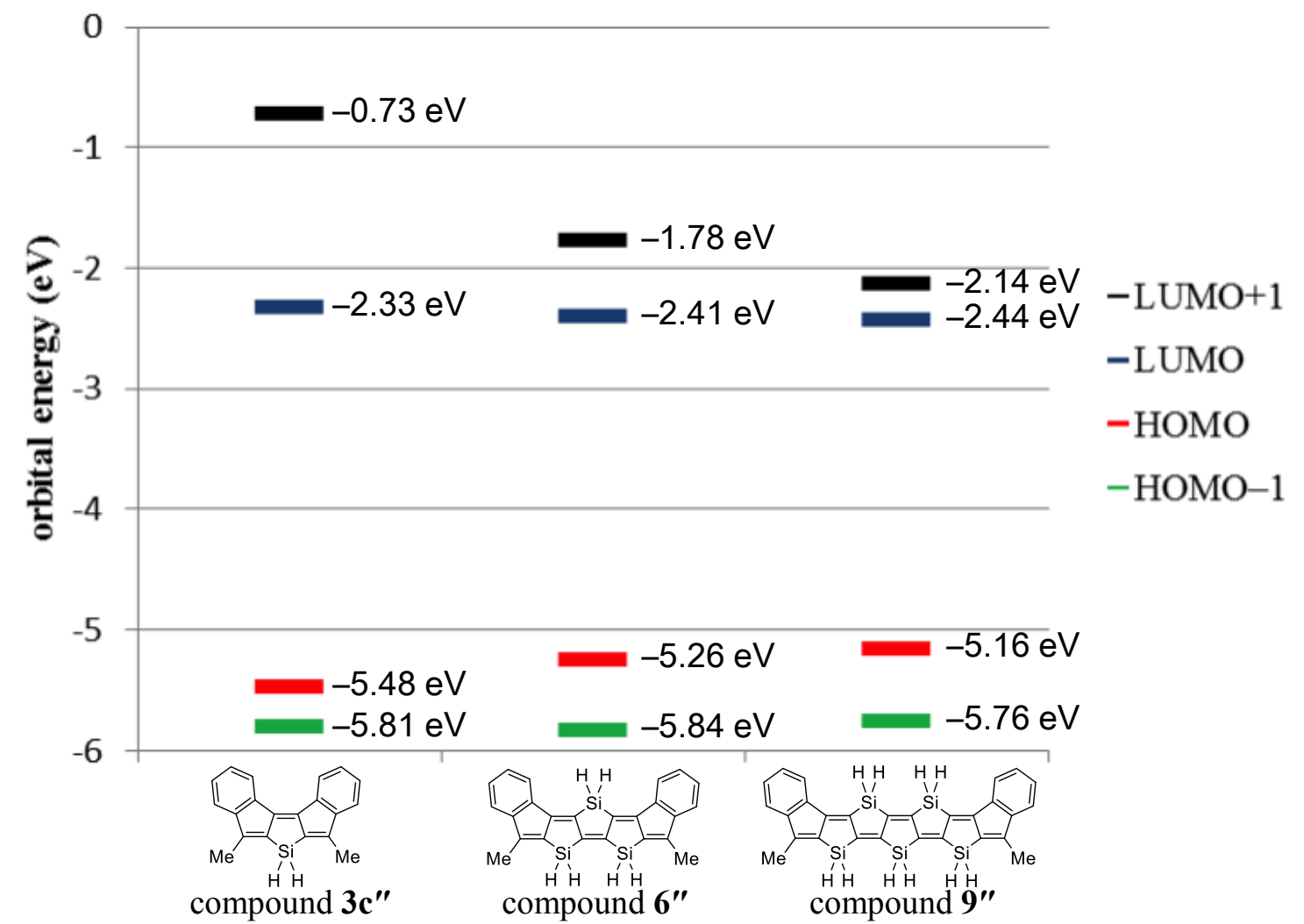

Figure S6. Molecular orbital energy diagrams of dihydrosilyl variants $3 \mathbf{c}^{\prime \prime}, \mathbf{6}^{\prime \prime}$, and 9" calculated at the B3LYP/6-31G(d) level of theory. 


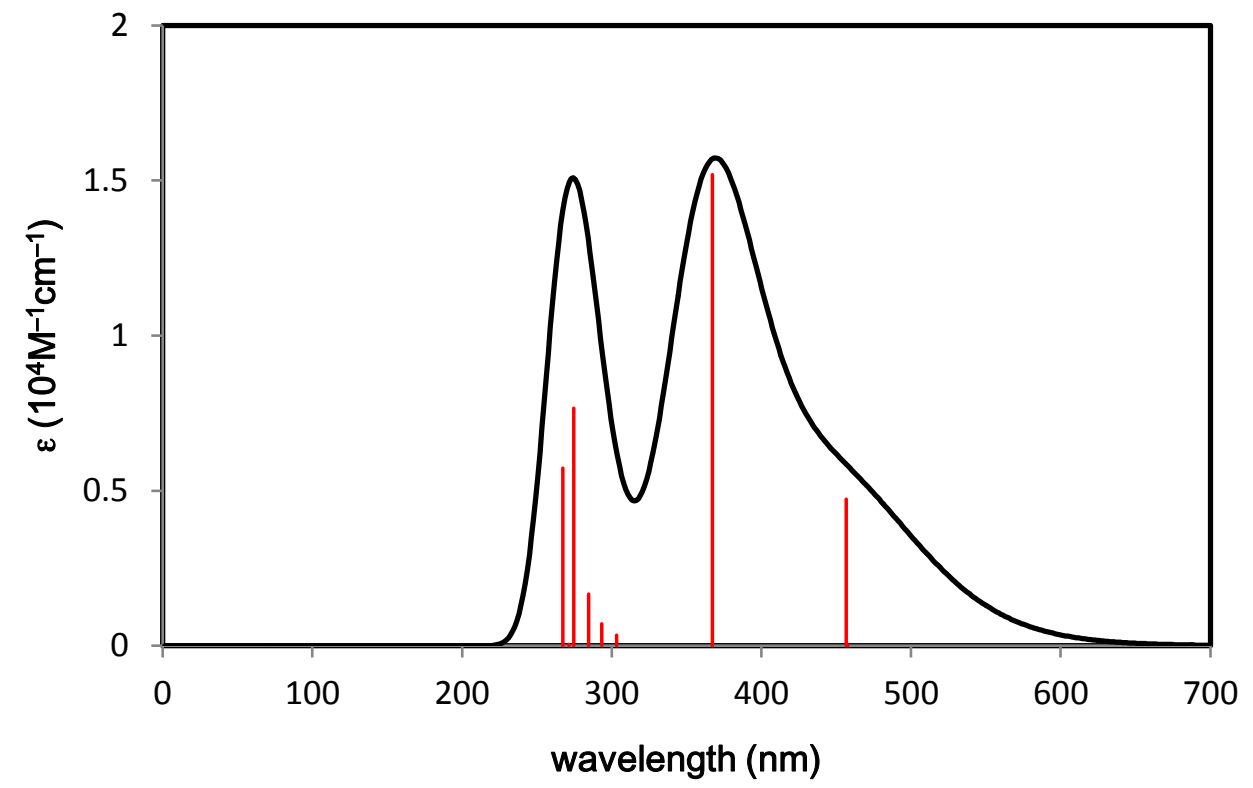

Figure S7. Absorption spectrum of compound 3c obtained by TD-DFT calculation at the B3LYP/6-31G(d) level of theory.

Table S2. Selected wavelengths, oscillator strengths, and compositions of major electronic transitions of compound 3c calculated at the B3LYP/6-31G(d) level of theory.

\begin{tabular}{ccl} 
wavelength $(\mathrm{nm})$ & oscillator strengths $(f)$ & \multicolumn{1}{c}{ Major Contributions } \\
\hline 456.6 & 0.1181 & $\begin{array}{l}\text { HOMO-2 } \rightarrow \text { LUMO }(23 \%) \\
\text { HOMO } \rightarrow \text { LUMO }(76 \%)\end{array}$ \\
\hline 367.2 & 0.3795 & $\begin{array}{l}\text { HOMO-2 } \rightarrow \text { LUMO }(74 \%) \\
\text { HOMO } \rightarrow \text { LUMO }(21 \%)\end{array}$ \\
\hline 274.5 & 0.1914 & $\begin{array}{l}\text { HOMO-5 } \rightarrow \text { LUMO }(74 \%) \\
\end{array}$ \\
\hline 267.4 & 0.1432 & HOMO-1 $\rightarrow$ LUMO+1 $(16 \%)$ \\
\hline & & HOMO-5 $\rightarrow$ LUMO $(13 \%)$ \\
& & HOMO $\rightarrow$ LUMO+2 $(13 \%)$ \\
\hline
\end{tabular}




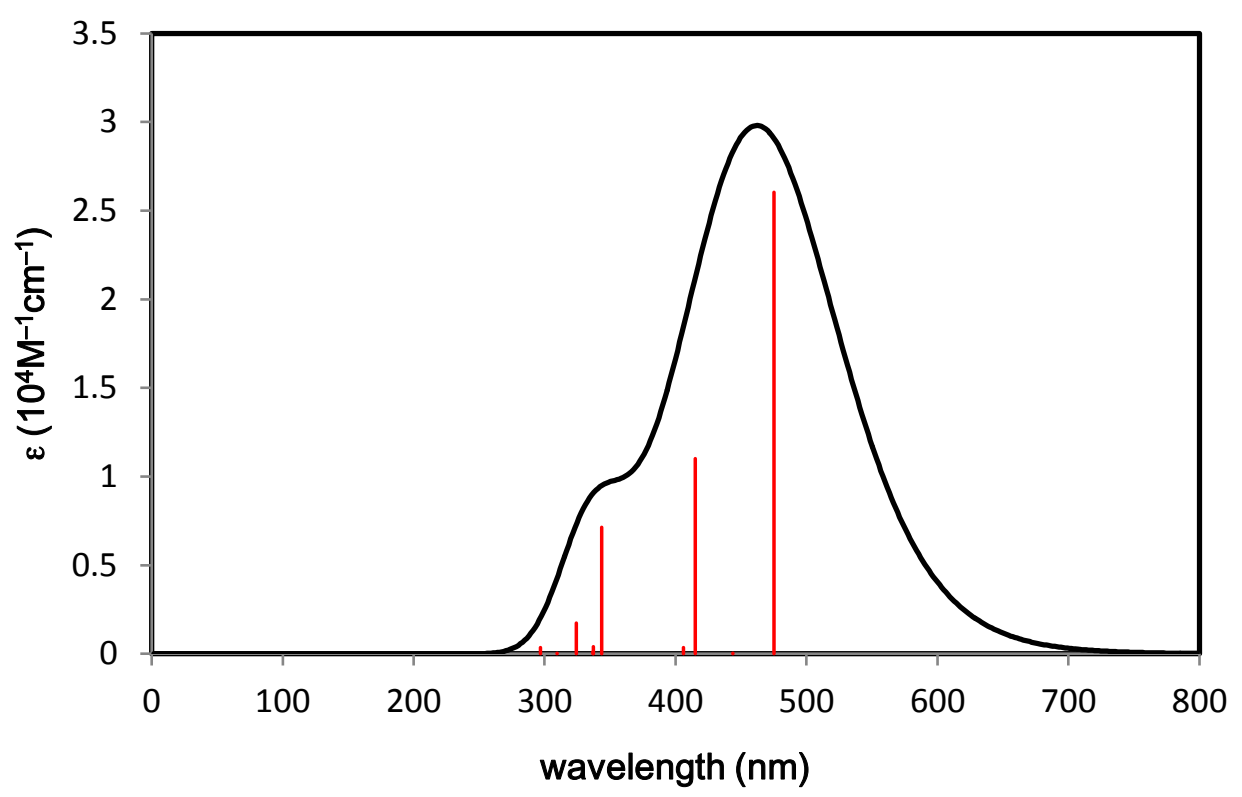

Figure S8. Absorption spectrum of compound $\mathbf{6}$ obtained by TD-DFT calculation at the B3LYP/6-31G(d) level of theory.

Table S3. Selected wavelengths, oscillator strengths, and compositions of major electronic transitions of compound $\mathbf{6}$ calculated at the B3LYP/6-31G(d) level of theory.

\begin{tabular}{ccl} 
wavelength $(\mathrm{nm})$ & oscillator strengths $(f)$ & \multicolumn{1}{c}{ Major Contributions } \\
\hline 475.3 & 0.6074 & $\begin{array}{l}\text { HOMO-2 } \rightarrow \text { LUMO }(11 \%) \\
\text { HOMO } \rightarrow \text { LUMO }(89 \%)\end{array}$ \\
\hline 415 & 0.2570 & $\begin{array}{l}\text { HOMO-2 } \rightarrow \text { LUMO }(82 \%) \\
\text { HOMO } \rightarrow \text { LUMO }(10 \%)\end{array}$ \\
\hline 343.5 & 0.1668 & HOMO-1 $\rightarrow$ LUMO+1 (90\%) \\
\hline
\end{tabular}




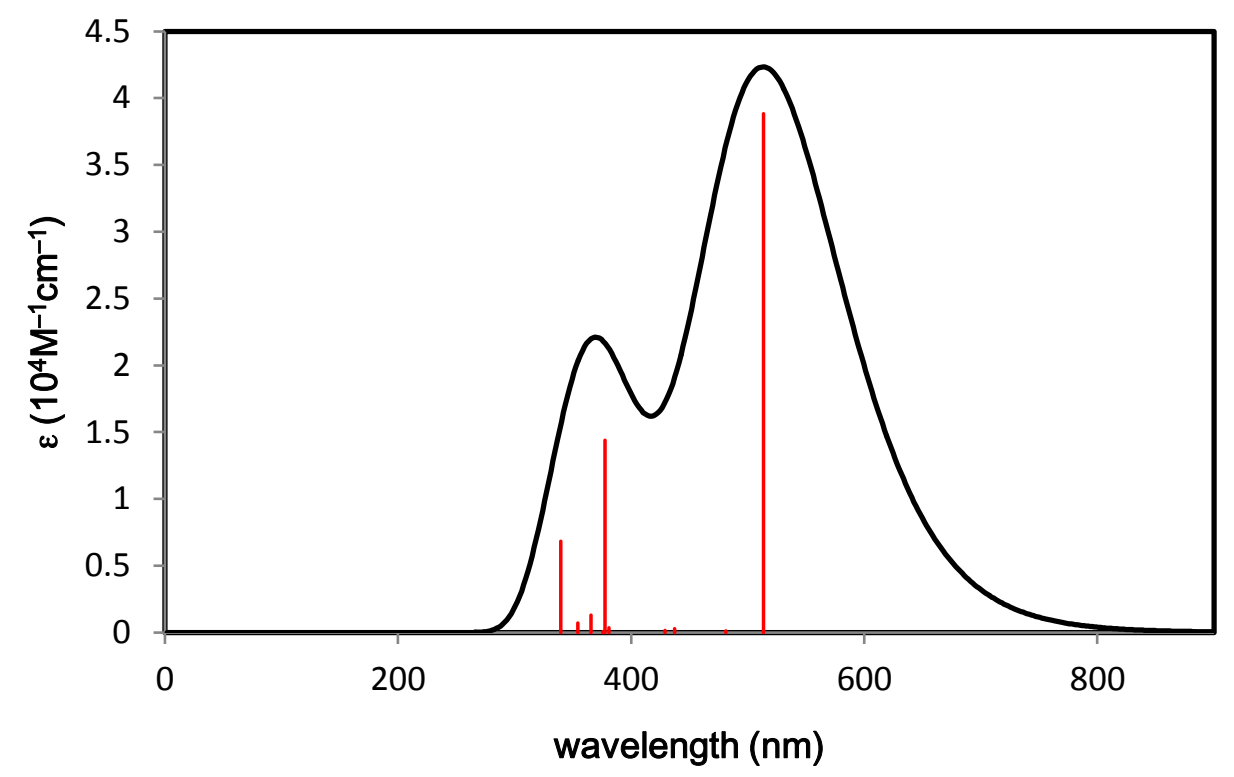

Figure S9. Absorption spectrum of compound 9 obtained by TD-DFT calculation at the B3LYP/6-31G(d) level of theory.

Table S4. Selected wavelengths, oscillator strengths, and compositions of major electronic transitions of compound 9 calculated at the B3LYP/6-31G(d) level of theory.

\begin{tabular}{ccc} 
wavelength $(\mathrm{nm})$ & oscillator strengths $(f)$ & \multicolumn{1}{c}{ Major Contributions } \\
\hline 513.4 & 1.0352 & HOMO $\rightarrow$ LUMO $(99 \%)$ \\
\hline 377.4 & 0.3836 & HOMO-2 $\rightarrow$ LUMO $(20 \%)$ \\
& & HOMO-1 $\rightarrow$ LUMO+1 $(48 \%)$ \\
\hline 339.5 & & HOMO $\rightarrow$ LUMO+2 $(28 \%)$ \\
\hline & 0.1823 & HOMO-3 $\rightarrow$ LUMO+1 (87\%) \\
\hline
\end{tabular}




\title{
Cartesian Coordinates of Optimized Species
}

\author{
compound 3c (B3LYP/6-31G(d))
}

$\begin{array}{lrrr}\mathrm{C} & -1.77017624 & 1.82021533 & -0.05989125 \\ \mathrm{C} & -1.80988229 & 3.20964822 & -0.15847699 \\ \mathrm{H} & -0.90209137 & 3.79466523 & -0.23642423 \\ \mathrm{C} & -3.04850762 & 3.86331109 & -0.19176721 \\ \mathrm{H} & -3.07817197 & 4.94686973 & -0.26681944 \\ \mathrm{C} & -4.24042489 & 3.13824186 & -0.13422457 \\ \mathrm{H} & -5.19257909 & 3.66177555 & -0.15815343 \\ \mathrm{C} & -4.21788581 & 1.74002762 & -0.05795761 \\ \mathrm{H} & -5.14837056 & 1.17856085 & -0.03020528 \\ \mathrm{C} & -2.98985439 & 1.08563752 & -0.02825264 \\ \mathrm{C} & 4.21893399 & 1.73770389 & 0.05746476 \\ \mathrm{H} & 5.14909699 & 1.17571568 & 0.02952414 \\ \mathrm{C} & 4.24225573 & 3.13589499 & 0.13389791 \\ \mathrm{H} & 5.19469804 & 3.65890626 & 0.15775679 \\ \mathrm{C} & 3.05074473 & 3.86160851 & 0.19173842 \\ \mathrm{H} & 3.08101596 & 4.94514061 & 0.26693502 \\ \mathrm{C} & 1.81175391 & 3.20863112 & 0.15856559 \\ \mathrm{H} & 0.90430057 & 3.79413462 & 0.23681201 \\ \mathrm{Si} & -0.00047326 & -1.84873680 & 0.00004867 \\ \mathrm{C} & 0.68740401 & 0.82812503 & 0.01279460 \\ \mathrm{C} & -0.68686061 & 0.82850947 & -0.01279580 \\ \mathrm{C} & -2.68341686 & -0.35586485 & 0.01114720 \\ \mathrm{C} & 1.32862279 & -0.51371012 & -0.01071638 \\ \mathrm{C} & -1.32881790 & -0.51296480 & 0.01062989 \\ \mathrm{C} & 2.68331127 & -0.35733757 & -0.01156578 \\ \mathrm{C} & 1.77126572 & 1.81923433 & 0.05976932 \\ \mathrm{C} & 2.99053573 & 1.08399548 & 0.02786237 \\ \mathrm{C} & 0.07376005 & -2.93507740 & 1.57522576\end{array}$

$\begin{array}{lrrr}\mathrm{H} & 1.03389303 & -3.47234633 & 1.51220592 \\ \mathrm{C} & 3.74620233 & -1.41207743 & -0.03005316 \\ \mathrm{H} & 3.31812729 & -2.41786130 & -0.00350023 \\ \mathrm{H} & 4.42200816 & -1.30881065 & 0.82992966 \\ \mathrm{H} & 4.37161450 & -1.33389655 & -0.93019009 \\ \mathrm{C} & -0.07541903 & -2.93596900 & -1.57446868 \\ \mathrm{H} & -1.03536931 & -3.47345125 & -1.51049961 \\ \mathrm{C} & -3.74686208 & -1.41004726 & 0.02958918 \\ \mathrm{H} & -3.31932253 & -2.41604676 & 0.00231768 \\ \mathrm{H} & -4.42304770 & -1.30599309 & -0.82999173 \\ \mathrm{H} & -4.37177684 & -1.33201314 & 0.93009257 \\ \mathrm{C} & 0.09703481 & -2.08673965 & 2.85999307 \\ \mathrm{H} & -0.83345024 & -1.51739595 & 2.97461303 \\ \mathrm{H} & 0.92474752 & -1.36922878 & 2.85971282 \\ \mathrm{H} & 0.20534181 & -2.72414459 & 3.74820044 \\ \mathrm{C} & -1.04567019 & -3.99153530 & 1.63596115 \\ \mathrm{H} & -0.92988519 & -4.63310701 & 2.52014305 \\ \mathrm{H} & -1.05286403 & -4.64531191 & 0.75577656 \\ \mathrm{H} & -2.03385014 & -3.52048763 & 1.70957404 \\ \mathrm{C} & 1.04426417 & -3.99216521 & -1.63524608 \\ \mathrm{H} & 0.92772910 & -4.63473121 & -2.51859526 \\ \mathrm{H} & 1.05262330 & -4.64497792 & -0.75436084 \\ \mathrm{H} & 2.03218295 & -3.52083786 & -1.71044835 \\ \mathrm{C} & -0.09972312 & -2.08838496 & -2.85972393 \\ \mathrm{H} & 0.83036764 & -1.51854308 & -2.97506504 \\ \mathrm{H} & -0.92786807 & -1.37138244 & -2.85948472 \\ \mathrm{H} & -0.20800354 & -2.72635142 & -3.74753172\end{array}$

compound 6 (B3LYP/6-31G(d))

$\begin{array}{lrrr}\mathrm{Si} & 0.00000227 & 2.08507547 & 0.00003267 \\ \mathrm{Si} & 2.04323597 & -1.92309549 & -0.15412074 \\ \mathrm{C} & 5.02433072 & 0.99387120 & 0.11865431 \\ \mathrm{C} & 0.68828586 & -0.57271434 & -0.04133865 \\ \mathrm{C} & 3.79653815 & 1.71209563 & 0.09297224 \\ \mathrm{C} & 1.35288784 & 0.75021144 & -0.04091753 \\ \mathrm{C} & 2.72592818 & 0.71057857 & -0.00576770 \\ \mathrm{C} & 3.38314244 & -0.61907674 & -0.03543972 \\ \mathrm{C} & 4.73609755 & -0.44928353 & 0.03883013 \\ \mathrm{C} & 6.24004658 & 1.66726585 & 0.21984306 \\ \mathrm{H} & 7.17974261 & 1.12077957 & 0.23952155 \\ \mathrm{C} & 0.14816894 & 3.12359379 & 1.60527771 \\ \mathrm{H} & 1.13493634 & 3.60555637 & 1.53549200 \\ \mathrm{C} & 3.80768986 & 3.10285861 & 0.18350433 \\ \mathrm{H} & 2.88556637 & 3.67331650 & 0.17603158 \\ \mathrm{C} & 2.05342594 & -2.80957609 & -1.86094859 \\ \mathrm{H} & 1.32134109 & -3.63034673 & -1.80132189 \\ \mathrm{C} & 1.96129843 & -3.13557873 & 1.33189088\end{array}$

$\begin{array}{lrrr}\mathrm{H} & 0.90218774 & -3.42898891 & 1.39759990 \\ \mathrm{C} & 5.03228359 & 3.77427467 & 0.28434633 \\ \mathrm{H} & 5.04415029 & 4.85873703 & 0.35292694 \\ \mathrm{C} & 6.23666578 & 3.06461222 & 0.30002265 \\ \mathrm{H} & 7.17793510 & 3.60229563 & 0.37909421 \\ \mathrm{C} & 5.81502459 & -1.48863897 & 0.06389957 \\ \mathrm{H} & 5.40552004 & -2.50088321 & 0.01144666 \\ \mathrm{H} & 6.41574179 & -1.41206218 & 0.98074923 \\ \mathrm{H} & 6.51169195 & -1.36264701 & -0.77648866 \\ \mathrm{C} & 1.62016182 & -1.86321579 & -2.99713231 \\ \mathrm{H} & 2.30801606 & -1.01281672 & -3.08333903 \\ \mathrm{H} & 0.61557566 & -1.45998432 & -2.84134295 \\ \mathrm{H} & 1.62691188 & -2.38766924 & -3.96237736 \\ \mathrm{C} & 2.78206807 & -4.42826695 & 1.17107922 \\ \mathrm{H} & 3.85460104 & -4.21752403 & 1.07313609 \\ \mathrm{H} & 2.47479977 & -5.01154820 & 0.29607489 \\ \mathrm{H} & 2.66222965 & -5.07266037 & 2.05287600 \\ \mathrm{C} & 2.32978240 & -2.42395955 & 2.64823045\end{array}$




$\begin{array}{rrrr}\mathrm{H} & 2.15973220 & -3.08418599 & 3.50939920 \\ \mathrm{H} & 1.74054917 & -1.51386565 & 2.80632180 \\ \mathrm{H} & 3.38642834 & -2.13222674 & 2.65635899 \\ \mathrm{C} & 0.17001793 & 2.22046296 & 2.85420019 \\ \mathrm{H} & 0.33029838 & 2.81914760 & 3.76089220 \\ \mathrm{H} & 0.96939206 & 1.47340363 & 2.80412543 \\ \mathrm{H} & -0.78058643 & 1.68719369 & 2.97542523 \\ \mathrm{C} & 3.42555380 & -3.42555116 & -2.20172985 \\ \mathrm{H} & 3.38433096 & -3.94339736 & -3.16978352 \\ \mathrm{H} & 3.76447826 & -4.15246329 & -1.45678981 \\ \mathrm{H} & 4.19208313 & -2.64601294 & -2.28230852 \\ \mathrm{C} & -0.90047870 & 4.23971784 & 1.76498002 \\ \mathrm{H} & -1.90617142 & 3.82635951 & 1.89907653 \\ \mathrm{H} & -0.92827334 & 4.91906377 & 0.90418236 \\ \mathrm{H} & -0.67981121 & 4.84799865 & 2.65260838 \\ \mathrm{Si} & -2.04324288 & -1.92309122 & 0.15412953 \\ \mathrm{C} & -5.02432756 & 0.99388002 & -0.11870207 \\ \mathrm{C} & -0.68828867 & -0.57271262 & 0.04136662 \\ \mathrm{C} & -3.79653369 & 1.71210191 & -0.09300747 \\ \mathrm{C} & -1.35288780 & 0.75021435 & 0.04094151 \\ \mathrm{C} & -2.72592745 & 0.71058361 & 0.00576207 \\ \mathrm{C} & -3.38314451 & -0.61907033 & 0.03542437 \\ \mathrm{C} & -4.73609837 & -0.44927471 & -0.03886322 \\ \mathrm{C} & -6.24004060 & 1.66727664 & -0.21991565 \\ \mathrm{H} & -7.17973774 & 1.12079244 & -0.23960235 \\ \mathrm{C} & -0.14815379 & 3.12363914 & -1.60518264 \\ \mathrm{H} & -1.13490435 & 3.60563231 & -1.53537204 \\ \mathrm{C} & -3.80768068 & 3.10286346 & -0.18356196 \\ \mathrm{H} & -2.88555572 & 3.67331883 & -0.17609059 \\ \mathrm{C} & -2.05346950 & -2.80956722 & 1.86096106 \\ \mathrm{H} & -1.32138932 & -3.63034311 & 1.80134992 \\ \mathrm{C} & -1.96127613 & -3.13557521 & -1.33188075 \\ \mathrm{H} & -0.90216630 & -3.42899621 & -1.39756094\end{array}$

compound 9 (B3LYP/6-31G(d))

$\begin{array}{lrrr}\mathrm{C} & -5.03227117 & 3.77428141 & -0.28442985 \\ \mathrm{H} & -5.04413420 & 4.85874271 & -0.35302741 \\ \mathrm{C} & -6.23665509 & 3.06462210 & -0.30011160 \\ \mathrm{H} & -7.17792197 & 3.60230684 & -0.37920349 \\ \mathrm{C} & -5.81502676 & -1.48862876 & -0.06394216 \\ \mathrm{H} & -5.40552417 & -2.50087313 & -0.01147509 \\ \mathrm{H} & -6.41572946 & -1.41205797 & -0.98080187 \\ \mathrm{H} & -6.51170703 & -1.36262946 & 0.77643429 \\ \mathrm{C} & -1.62022136 & -1.86320715 & 2.99715144 \\ \mathrm{H} & -2.30806861 & -1.01280064 & 3.08334065 \\ \mathrm{H} & -0.61562749 & -1.45998642 & 2.84138512 \\ \mathrm{H} & -1.62699893 & -2.38765776 & 3.96239778 \\ \mathrm{C} & -2.78206125 & -4.42825690 & -1.17109562 \\ \mathrm{H} & -3.85459445 & -4.21750476 & -1.07317465 \\ \mathrm{H} & -2.47481695 & -5.01154780 & -0.29608946 \\ \mathrm{H} & -2.66220964 & -5.07264520 & -2.05289442 \\ \mathrm{C} & -2.32971497 & -2.42395129 & -2.64823062 \\ \mathrm{H} & -2.15964796 & -3.08417913 & -3.50939499 \\ \mathrm{H} & -1.74046772 & -1.51386363 & -2.80630596 \\ \mathrm{H} & -3.38635780 & -2.13220759 & -2.65638868 \\ \mathrm{C} & -0.17004986 & 2.22054129 & -2.85412889 \\ \mathrm{H} & -0.33032393 & 2.81925526 & -3.76080268 \\ \mathrm{H} & -0.96944873 & 1.47350806 & -2.80406131 \\ \mathrm{H} & 0.78053477 & 1.68724340 & -2.97538393 \\ \mathrm{C} & -3.42560752 & -3.42553043 & 2.20172260 \\ \mathrm{H} & -3.38440552 & -3.94336899 & 3.16978125 \\ \mathrm{H} & -3.76452412 & -4.15244581 & 1.45678246 \\ \mathrm{H} & -4.19213345 & -2.64598659 & 2.28228157 \\ \mathrm{C} & 0.90053117 & 4.23973084 & -1.76486516 \\ \mathrm{H} & 1.90620946 & 3.82634116 & -1.89897401 \\ \mathrm{H} & 0.92835241 & 4.91905510 & -0.90405134 \\ \mathrm{H} & 0.67988054 & 4.84803979 & -2.65247843\end{array}$

$\begin{array}{rrrrrrrr}\mathrm{Si} & 0.00002869 & 1.98482317 & 0.00002405 & \mathrm{C} & -5.77743719 & -3.05479811 & 0.53101689 \\ \mathrm{Si} & -4.16254995 & 1.93820664 & -0.38712397 & \mathrm{H} & -4.85069184 & -3.60980501 & 0.44848026 \\ \mathrm{Si} & -2.03144687 & -2.00548239 & -0.04786428 & \mathrm{C} & -2.01625031 & -3.02208338 & -1.68203621 \\ \mathrm{C} & -0.68848663 & -0.65404900 & -0.03660083 & \mathrm{H} & -1.16728417 & -3.71682510 & -1.58567995 \\ \mathrm{C} & -1.36981167 & 0.66099800 & -0.11337161 & \mathrm{C} & -4.38678772 & 2.50247830 & -2.21818267 \\ \mathrm{C} & -3.39765894 & -0.68666868 & -0.04350016 & \mathrm{H} & -3.74507129 & 3.38202403 & -2.37299055 \\ \mathrm{C} & -2.75128657 & 0.64466464 & -0.17612309 & \mathrm{C} & -7.88245655 & 1.48451650 & 0.29918928 \\ \mathrm{C} & -5.44930692 & 0.64622009 & 0.03192216 & \mathrm{H} & -7.51302902 & 2.49057813 & 0.08610655 \\ \mathrm{C} & -4.76423910 & -0.66546703 & 0.09626184 & \mathrm{H} & -8.36456031 & 1.50161343 & 1.28656528 \\ \mathrm{C} & -7.03401836 & -0.97088695 & 0.46635784 & \mathrm{H} & -8.67201113 & 1.25371796 & -0.42920554 \\ \mathrm{C} & -6.78525076 & 0.46530467 & 0.25231638 & \mathrm{C} & -6.97125916 & -3.73567781 & 0.79877569 \\ \mathrm{C} & -5.80107220 & -1.67235852 & 0.36270134 & \mathrm{H} & -6.95526271 & -4.81453563 & 0.92822239 \\ \mathrm{C} & -8.21943520 & -1.65243657 & 0.73471245 & \mathrm{C} & -5.04782974 & 4.55194619 & 0.59245259 \\ \mathrm{H} & -9.16285578 & -1.11823492 & 0.81607898 & \mathrm{H} & -6.08453504 & 4.21476754 & 0.71516122 \\ \mathrm{C} & -4.04111287 & 3.41107568 & 0.83248815 & \mathrm{H} & -4.95267048 & 4.98633175 & -0.40846904 \\ \mathrm{H} & -3.04012061 & 3.83539135 & 0.66533826 & \mathrm{H} & -4.88771023 & 5.36148530 & 1.31777778 \\ \mathrm{C} & 0.21678077 & 3.06145097 & -1.57309654 & \mathrm{C} & -8.18066487 & -3.04184210 & 0.89992195 \\ \mathrm{H} & 1.20767763 & 3.52433038 & -1.46573738 & \mathrm{H} & -9.09827076 & -3.58574878 & 1.10854955\end{array}$




\begin{tabular}{|c|c|c|c|c|c|c|c|}
\hline- & -4.11253769 & 2.92513698 & 2.29294163 & $\mathrm{H}$ & -1.20749522 & 3.52433471 & 年 \\
\hline $\mathrm{H}$ & -3.93745062 & 3.75527245 & 2.99084581 & $\mathrm{C}$ & 5.77740840 & -3.05479607 & 136143 \\
\hline 1 & -3.37051345 & 2.14806010 & 2.50583851 & $\mathrm{H}$ & 4.85065903 & -3.60980363 & -0.44888143 \\
\hline $\mathrm{H}$ & -5.09940733 & 2.50464123 & 2.51927666 & $\mathrm{C}$ & 2.01613843 & -3.02196616 & 1.68224250 \\
\hline $\mathrm{C}$ & -1.88151393 & -3.06686046 & 1.55424693 & $\mathrm{H}$ & 1.16716309 & -3.71669905 & 1.58590085 \\
\hline $\mathrm{H}$ & -0.80613285 & -3.01367216 & 1.76905302 & $\mathrm{C}$ & 4.38677593 & 2.50248077 & 2.21812724 \\
\hline $\mathrm{C}$ & 0.24735378 & 2.20911761 & -2.85528527 & $\mathrm{H}$ & 3.74506812 & 3.38203885 & 2.37290870 \\
\hline $\mathrm{H}$ & -0.71770005 & 1.72081931 & -3.03188910 & $\mathrm{C}$ & 7.88246063 & 1.48448628 & -0.29924966 \\
\hline $\mathrm{H}$ & 1.00967275 & 1.42380058 & -2.80578089 & $\mathrm{H}$ & 7.51304284 & 2.49054234 & -0.08612538 \\
\hline $\mathrm{H}$ & 0.46661506 & 2.83181823 & -3.73312459 & $\mathrm{H}$ & 8.36454205 & 1.50161366 & -1.28663604 \\
\hline $\mathrm{C}$ & -0.80464524 & 4.20603955 & -1.69973359 & $\mathrm{H}$ & 8.67203092 & 1.25366016 & 1940 \\
\hline $\mathrm{H}$ & -0.59773316 & 4.81332224 & -2.59162814 & $\mathrm{C}$ & 6.97122264 & -3.73566134 & -0.79919196 \\
\hline $\mathrm{H}$ & -0.79095503 & 4.87954603 & -0.83527498 & $\mathrm{H}$ & 6.95521445 & -4.81450586 & -0.92874792 \\
\hline $\mathrm{H}$ & -1.82448273 & 3.82211213 & -1.80392063 & $\mathrm{C}$ & 5.04775889 & 4.55192946 & -0.59254966 \\
\hline $\mathrm{C}$ & -3.95292529 & 1.41711729 & -3.22085070 & $\mathrm{H}$ & 6.08446763 & 4.21477211 & 28623 \\
\hline $\mathrm{H}$ & -4.55536043 & 0.50779363 & -3.10 & $\mathrm{H}$ & 61870 & 4.98632100 & 37114 \\
\hline $\mathrm{H}$ & -2.90321357 & 1.13446620 & -3.09662359 & $\mathrm{H}$ & 4.88760161 & 5.36145989 & -1.31787618 \\
\hline $\mathrm{H}$ & -4.08768399 & 1.76650106 & -4.25361090 & $\mathrm{C}$ & 8.18063560 & -3.04182900 & 26968 \\
\hline $\mathrm{C}$ & -3.27766023 & -3.87286911 & -1.926 & $\mathrm{H}$ & 9.09823467 & 72363 & 95880 \\
\hline $\mathrm{H}$ & -4.17594220 & -3.24876366 & -1.99126672 & $\mathrm{C}$ & 4.11245546 & 2.92508876 & 00070 \\
\hline $\mathrm{H}$ & -3.44213105 & -4.619 & -1.143 & $\mathrm{H}$ & 4665 & 1784 & 90711 \\
\hline $\mathrm{H}$ & -3.18885855 & -4.41543431 & -2.8 & $\mathrm{H}$ & 3.37 & 0421 & 7596 \\
\hline $\mathrm{C}$ & -2.60299230 & -2.41390267 & 2.750 & $\mathrm{H}$ & 2383 & 9949 & -2.51935359 \\
\hline $\mathrm{H}$ & -3.69086843 & -2.42474410 & 2.62 & $\mathrm{C}$ & 57635 & 1596 & 05236 \\
\hline $\mathrm{H}$ & -2.29978171 & -1.36975814 & 2.89 & $\mathrm{H}$ & 0.8 & 4272 & 1892 \\
\hline $\mathrm{H}$ & -2.37283638 & -2.95244516 & 3.67 & $\mathrm{C}$ & -0.24727268 & 4475 & 4373 \\
\hline $\mathrm{C}$ & -1.75319263 & -2.12093753 & -2.90465553 & $\mathrm{H}$ & 74148 & 5189 & 0634 \\
\hline $\mathrm{H}$ & -1.66347177 & -2.72612792 & -3.81692879 & $\mathrm{H}$ & -1.00965810 & 9578 & 8963 \\
\hline $\mathrm{H}$ & -0.83590286 & -1.53228586 & -2.800 & $\mathrm{H}$ & -0.46 & 0257 & 2817 \\
\hline $\mathrm{H}$ & -2.58087565 & -1.41899684 & -3.05977092 & $\mathrm{C}$ & 0.804 & 5061 & 2883 \\
\hline $\mathrm{C}$ & -5.83816509 & 2.92881799 & -2.52082039 & $\mathrm{H}$ & 0.59803283 & 4.81310110 & 5666 \\
\hline $\mathrm{H}$ & -5.92676132 & 3.27358848 & -3.56022789 & $\mathrm{H}$ & 0.79127736 & 0873 & 50921 \\
\hline $\mathrm{H}$ & -6.18662916 & 3.74261965 & -1.87662655 & $\mathrm{H}$ & 1.82469751 & 2158 & 10373 \\
\hline $\mathrm{H}$ & -6.52648092 & 2.08530075 & -2.39569611 & $\mathrm{C}$ & 3.95287986 & 1.41714741 & 31040 \\
\hline $\mathrm{C}$ & -2.22944925 & -4.56276665 & 1.44611293 & $\mathrm{H}$ & 4.55530519 & 1389 & 1887 \\
\hline $\mathrm{H}$ & -1.95596148 & -5.08380335 & 2.37376618 & $\mathrm{H}$ & 2.90316635 & 50699 & 3.09657183 \\
\hline $\mathrm{H}$ & -1.69841275 & -5.05649824 & 0.62407559 & $\mathrm{H}$ & 4.08762652 & 1.76654912 & 4.25356611 \\
\hline $\mathrm{H}$ & -3.30184825 & -4.72883506 & 1.29610144 & $\mathrm{C}$ & 3.27750793 & -3.87275933 & 1.92736431 \\
\hline $\mathrm{Si}$ & 4.16255135 & 1.93817991 & 0.38707433 & $\mathrm{H}$ & 4.17579811 & -3.24866982 & 1.99167414 \\
\hline $\mathrm{Si}$ & 2.03144144 & -2.00550896 & 0.04797661 & $\mathrm{H}$ & 3.44202456 & -4.61918373 & 1.14 \\
\hline $\mathrm{C}$ & 0.68849386 & -0.65406021 & 0.036 & $\mathrm{H}$ & 3.18861259 & -4.41524643 & 4796 \\
\hline $\mathrm{C}$ & 1.36983325 & 0.66097289 & 0.11336007 & $\mathrm{C}$ & 2.60312794 & -2.41415838 & -2.75013525 \\
\hline $\mathrm{C}$ & 3.39766934 & -0.68670598 & 0.04352440 & $\mathrm{H}$ & 3.69099619 & -2.42499484 & -2.62086127 \\
\hline $\mathrm{C}$ & 2.75130327 & 0.64463042 & 0.17610400 & $\Pi$ & 2.29993108 & -1.37002354 & -2.89029761 \\
\hline $\mathrm{C}$ & 5.44930861 & 0.64619180 & -0.031 & 11 & 2.37302695 & -2.95277509 & -3.67950377 \\
\hline $\mathrm{C}$ & 4.76424236 & -0.66549985 & -0.096 & C & & -2.12070181 & 2.90476017 \\
\hline $\mathrm{C}$ & 7.03 & -0.97 & -0.46 & 11 & & & 3.8 \\
\hline $\mathrm{C}$ & & & -0.25 & 11 & & -1.53 & 7022 \\
\hline $\mathrm{C}$ & & -1.67237469 & -0.36 & II & & -1.41875638 & 3.0 \\
\hline $\mathrm{C}$ & 8.219 & -1.65243919 & -0.73 & C & 5.83 & 2.92880564 & 2.52077737 \\
\hline 11 & 9.16284054 & -1.11823620 & -0.81627183 & & 5.92674010 & 3.27359576 & 3.56017929 \\
\hline & 4.04105868 & 3.41103690 & & & 6.18664101 & 3.74259031 & 1.87657357 \\
\hline $\mathrm{H}$ & & & & & & & 2.39568110 \\
\hline & -0.21663769 & 3.06136493 & 1.57321421 & $\mathrm{C}$ & 2.22951785 & -4.56290984 & -1.4457756 \\
\hline
\end{tabular}


H $\quad 1.95608139 \quad-5.08402662 \quad-2.37339896$

H $\quad 1.69844475 \quad-5.05657755 \quad-0.62372351$

compound 3c' (B3LYP/6-31G(d))
H $\quad 3.30191183 \quad-4.72895250 \quad-1.29569694$

$\begin{array}{rrrr}\mathrm{C} & -3.72944970 & 2.01217847 & -0.12128664 \\ \mathrm{H} & 0.91469384 & -3.20872977 & -0.22186587 \\ \mathrm{H} & 3.09526352 & -4.35572686 & -0.20754601 \\ \mathrm{H} & 5.20297991 & -3.06479881 & -0.05367655 \\ \mathrm{H} & 5.14991616 & -0.58185862 & 0.07605446 \\ \mathrm{H} & -5.14992765 & -0.58187332 & -0.07559245 \\ \mathrm{H} & -5.20296363 & -3.06482229 & 0.05398693 \\ \mathrm{H} & -3.09521649 & -4.35575470 & 0.20741623 \\ \mathrm{H} & -0.91464979 & -3.20875399 & 0.22145115 \\ \mathrm{H} & -0.06808049 & 2.90722438 & 2.45594271 \\ \mathrm{H} & 0.83588245 & 4.16834250 & 1.59996810 \\ \mathrm{H} & -0.93265716 & 4.16190482 & 1.55148717 \\ \mathrm{H} & 0.06782812 & 2.90670383 & -2.45610562 \\ \mathrm{H} & -0.83574847 & 4.16824687 & -1.60035692 \\ \mathrm{H} & 0.93280608 & 4.16142792 & -1.55210733 \\ \mathrm{H} & 4.40887424 & 1.94883495 & -0.73941830 \\ \mathrm{H} & 3.28725929 & 3.01293523 & 0.12933450 \\ \mathrm{H} & 4.35262813 & 1.91103098 & 1.02083031 \\ \mathrm{H} & -3.28728576 & 3.01292230 & -0.12920316 \\ \mathrm{H} & -4.35297290 & 1.91092856 & -1.02021007 \\ \mathrm{H} & -4.40860287 & 1.94892119 & 0.74005406\end{array}$

compound 6' (B3LYP/6-31G(d))

$\begin{array}{lrrr}\mathrm{Si} & 0.00000253 & -1.70301887 & 0.00018346 \\ \mathrm{C} & -1.34621267 & -0.37351157 & 0.00012071 \\ \mathrm{C} & -0.68850171 & 0.95013536 & 0.00011285 \\ \mathrm{C} & 0.68851257 & 0.95013054 & 0.00013514 \\ \mathrm{C} & 1.34622325 & -0.37351750 & 0.00008952 \\ \mathrm{C} & -2.71635510 & -0.34447574 & 0.00010718 \\ \mathrm{C} & -3.38288857 & 0.97677133 & -0.00005502 \\ \mathrm{Si} & 2.04854622 & 2.29004102 & 0.00016514 \\ \mathrm{C} & 3.38290137 & 0.97676535 & 0.00003062 \\ \mathrm{Si} & -2.04853295 & 2.29004671 & -0.00005894 \\ \mathrm{C} & 2.71636491 & -0.34447984 & 0.00003506 \\ \mathrm{C} & 4.73528968 & 0.79108981 & -0.00010683 \\ \mathrm{C} & 5.00977673 & -0.65938527 & -0.00013608 \\ \mathrm{C} & 3.77145939 & -1.36026200 & -0.00011469 \\ \mathrm{C} & -3.77145336 & -1.36025453 & 0.00010935 \\ \mathrm{C} & -5.00976852 & -0.65937287 & -0.00015531 \\ \mathrm{C} & -4.73527741 & 0.79110068 & -0.00024385 \\ \mathrm{C} & -3.75440756 & -2.75303805 & 0.00031600 \\ \mathrm{C} & -4.96934356 & -3.44888715 & 0.00020671 \\ \mathrm{C} & -6.18591027 & -2.75865991 & -0.00008795 \\ \mathrm{C} & -6.21498946 & -1.35863587 & -0.00025771 \\ \mathrm{C} & 6.21499427 & -1.35865410 & -0.00024153 \\ \mathrm{C} & 6.18590646 & -2.75867806 & -0.00033688 \\ \mathrm{C} & 4.96933594 & -3.44889932 & -0.00031784\end{array}$

$\begin{array}{crrr}\text { C } & 3.75440408 & -2.75304396 & -0.00021185 \\ \mathrm{C} & -2.04868954 & 3.37765716 & 1.54895632 \\ \mathrm{C} & -2.04833569 & 3.37752413 & -1.54916577 \\ \mathrm{C} & 2.04839935 & 3.37777921 & -1.54875751 \\ \mathrm{C} & 2.04865104 & 3.37739602 & 1.54936106 \\ \mathrm{C} & -5.81538840 & 1.82874199 & -0.00047534 \\ \mathrm{C} & 5.81540481 & 1.82872677 & -0.00015592 \\ \mathrm{C} & -0.00019564 & -2.76702548 & -1.56383796 \\ \mathrm{C} & 0.00010304 & -2.76676268 & 1.56438366 \\ \mathrm{H} & -2.81661377 & -3.30220485 & 0.00057702 \\ \mathrm{H} & -4.96656429 & -4.53558584 & 0.00035149 \\ \mathrm{H} & -7.11930247 & -3.31561521 & -0.00016766 \\ \mathrm{H} & -7.16638803 & -0.83226484 & -0.00045470 \\ \mathrm{H} & 7.16639607 & -0.83228890 & -0.00027738 \\ \mathrm{H} & 7.11929559 & -3.31563861 & -0.00043291 \\ \mathrm{H} & 4.96655212 & -4.53559806 & -0.00039167 \\ \mathrm{H} & 2.81660548 & -3.30220327 & -0.00020667 \\ \mathrm{H} & -1.18856619 & 4.05700149 & 1.56822383 \\ \mathrm{H} & -2.95627038 & 3.99246522 & 1.58975443 \\ \mathrm{H} & -2.01687145 & 2.76793155 & 2.45813693 \\ \mathrm{H} & -2.95684952 & 3.99087166 & -1.59117372 \\ \mathrm{H} & -1.18927846 & 4.05825607 & -1.56726564 \\ \mathrm{H} & -2.01432356 & 2.76786569 & -2.45830868 \\ \mathrm{H} & 2.01421504 & 2.76828885 & -2.45800640\end{array}$




$\begin{array}{rrrr}\mathrm{H} & 1.18945226 & 4.05865597 & -1.56666394 \\ \mathrm{H} & 2.95700780 & 3.99098878 & -1.59073093 \\ \mathrm{H} & 2.01694737 & 2.76751214 & 2.45843964 \\ \mathrm{H} & 2.95616329 & 3.99230152 & 1.59021888 \\ \mathrm{H} & 1.18844841 & 4.05663493 & 1.56878727 \\ \mathrm{H} & -6.46490352 & 1.72930289 & 0.88014584 \\ \mathrm{H} & -5.40062811 & 2.84127177 & -0.00053382 \\ \mathrm{H} & -6.46471762 & 1.72911506 & -0.88121168 \\ \mathrm{H} & 5.40064923 & 2.84125850 & -0.00014477\end{array}$

compound 9' (B3LYP/6-31G(d))

$\begin{array}{rrrr}\mathrm{H} & 6.46485140 & 1.72919664 & 0.88050528 \\ \mathrm{H} & 6.46480160 & 1.72918419 & -0.88085222 \\ \mathrm{H} & 0.88498692 & -3.41205131 & -1.60859890 \\ \mathrm{H} & -0.88729522 & -3.40930813 & -1.61006617 \\ \mathrm{H} & 0.00151054 & -2.13581888 & -2.45888829 \\ \mathrm{H} & -0.00035267 & -2.13534796 & 2.45929237 \\ \mathrm{H} & -0.88576801 & -3.41079036 & 1.60985249 \\ \mathrm{H} & 0.88653172 & -3.40999758 & 1.61019862\end{array}$


H $\quad-9.16071129 \quad-3.39527812 \quad-0.00032826$

H $\quad-7.00658909 \quad-4.61325135 \quad-0.00017902$

compound 3c" (B3LYP/6-31G(d))
H $\quad-4.85805065 \quad-3.37807915 \quad-0.00008082$

$\begin{array}{crrr}\mathrm{H} & 0.03001074 & 3.68249491 & -1.19819537 \\ \mathrm{H} & -0.03003290 & 3.68267338 & 1.19763557 \\ \mathrm{C} & -3.72446964 & 2.40701941 & -0.10946063 \\ \mathrm{C} & 3.72442178 & 2.40703939 & 0.11001855 \\ \mathrm{H} & 5.15162285 & -0.18821641 & 0.06600621 \\ \mathrm{H} & 5.20799193 & -2.67174165 & -0.05486485 \\ \mathrm{H} & 3.10201749 & -3.96633239 & -0.19668610 \\ \mathrm{H} & 0.91948997 & -2.82355021 & -0.20867203 \\ \mathrm{H} & -0.91943087 & -2.82357395 & 0.20819534 \\ \mathrm{H} & -3.10195231 & -3.96636085 & 0.19663061 \\ \mathrm{H} & -5.20796397 & -2.67177641 & 0.05529337 \\ \mathrm{H} & -5.15163271 & -0.18824884 & -0.06553506 \\ \mathrm{H} & -3.27543375 & 3.40463217 & -0.12031349 \\ \mathrm{H} & -4.35235759 & 2.30795938 & -1.00536006 \\ \mathrm{H} & -4.39889003 & 2.34760116 & 0.75564387 \\ \mathrm{H} & 3.27538530 & 3.40465771 & 0.12030913 \\ \mathrm{H} & 4.35168345 & 2.30820400 & 1.00638438 \\ \mathrm{H} & 4.39944417 & 2.34739392 & -0.75459721\end{array}$

compound 6" (B3LYP/6-31G(d))

$\begin{array}{lrrr}\mathrm{C} & -2.71902595 & 0.03012629 & 0.00052440 \\ \mathrm{C} & -1.35140251 & 0.06405207 & 0.00112135 \\ \mathrm{C} & -3.38036172 & -1.29563665 & 0.00000599 \\ \mathrm{Si} & -2.03514612 & -2.58691662 & 0.00056048 \\ \mathrm{C} & -0.68580589 & -1.25310738 & 0.00106171 \\ \mathrm{C} & -3.77742946 & 1.03884345 & 0.00010886 \\ \mathrm{C} & -5.01213950 & 0.33330557 & -0.00072767 \\ \mathrm{C} & -4.73272778 & -1.11808122 & -0.00077763 \\ \mathrm{C} & 0.68580589 & -1.25310711 & 0.00104528 \\ \mathrm{C} & 1.35140247 & 0.06405234 & 0.00109918 \\ \mathrm{Si} & -0.00000023 & 1.37618459 & 0.00170774 \\ \mathrm{Si} & 2.03514626 & -2.58691651 & 0.00056750 \\ \mathrm{C} & 3.38036180 & -1.29563667 & -0.00000289 \\ \mathrm{C} & 2.71902596 & 0.03012643 & 0.00050741 \\ \mathrm{C} & 4.73272781 & -1.11808118 & -0.00075500 \\ \mathrm{C} & 5.01213957 & 0.33330556 & -0.00072973 \\ \mathrm{C} & 3.77742954 & 1.03884349 & 0.00008744 \\ \mathrm{C} & -3.75850199 & 2.43068631 & 0.00036473 \\ \mathrm{C} & -4.97565928 & 3.12309039 & -0.00022589 \\ \mathrm{C} & -6.19028112 & 2.42969967 & -0.00105290 \\ \mathrm{C} & -6.21843980 & 1.02898842 & -0.00131143 \\ \mathrm{C} & 6.21843985 & 1.02898838 & -0.00131172 \\ \mathrm{C} & 6.19028127 & 2.42969971 & -0.00106764 \\ \mathrm{C} & 4.97565939 & 3.12309039 & -0.00026456\end{array}$

$\begin{array}{crcc}\mathrm{C} & 3.75850203 & 2.43068632 & 0.00031989 \\ \mathrm{C} & -5.80404840 & -2.16286558 & -0.00162410 \\ \mathrm{C} & 5.80404829 & -2.16286573 & -0.00156444 \\ \mathrm{H} & -1.99566685 & -3.46715680 & 1.20186564 \\ \mathrm{H} & -1.99466297 & -3.46745662 & -1.20048789 \\ \mathrm{H} & 0.00001597 & 2.25056609 & 1.20642230 \\ \mathrm{H} & -0.00001678 & 2.25217424 & -1.20183021 \\ \mathrm{H} & 1.99467045 & -3.46748923 & -1.20045340 \\ \mathrm{H} & 1.99565900 & -3.46712402 & 1.20190005 \\ \mathrm{H} & -2.82016675 & 2.98015645 & 0.00099307 \\ \mathrm{H} & -4.97603018 & 4.20958629 & -0.00004360 \\ \mathrm{H} & -7.12460165 & 2.98484020 & -0.00149941 \\ \mathrm{H} & -7.16910027 & 0.50168089 & -0.00195633 \\ \mathrm{H} & 7.16910043 & 0.50168092 & -0.00193596 \\ \mathrm{H} & 7.12460186 & 2.98484007 & -0.00150740 \\ \mathrm{H} & 4.97603017 & 4.20958631 & -0.00009465 \\ \mathrm{H} & 2.82016685 & 2.98015656 & 0.00092914 \\ \mathrm{H} & -6.45225836 & -2.06634650 & -0.88319631 \\ \mathrm{H} & -5.38092848 & -3.17169179 & -0.00105333 \\ \mathrm{H} & -6.45396469 & -2.06605221 & 0.87865311 \\ \mathrm{H} & 5.38092806 & -3.17169184 & -0.00101675 \\ \mathrm{H} & 6.45229238 & -2.06634104 & -0.88311065 \\ \mathrm{H} & 6.45393056 & -2.06605829 & 0.87873876\end{array}$

compound 9"' (B3LYP/6-31G(d)) 


$\begin{array}{lrrr}\mathrm{C} & -4.75974354 & 0.15690524 & -0.00001361 \\ \mathrm{C} & -3.39233682 & 0.19210405 & 0.00021980 \\ \mathrm{C} & -5.42130095 & -1.16908882 & -0.00019748 \\ \mathrm{Si} & -4.07656388 & -2.46013165 & 0.00000141 \\ \mathrm{C} & -2.72687609 & -1.12599938 & 0.00023690 \\ \mathrm{C} & -5.81847922 & 1.16546511 & -0.00013977 \\ \mathrm{C} & -7.05306144 & 0.45997835 & -0.00033769 \\ \mathrm{C} & -6.77358383 & -0.99151853 & -0.00040251 \\ \mathrm{C} & -1.35624159 & -1.12555281 & 0.00036515 \\ \mathrm{C} & -0.68491982 & 0.19232111 & 0.00046403 \\ \mathrm{Si} & -2.04034002 & 1.50329575 & 0.00054874 \\ \mathrm{Si} & 0.00000005 & -2.43593167 & 0.00044847 \\ \mathrm{C} & 1.35624155 & -1.12555290 & 0.00036137 \\ \mathrm{C} & 0.68491989 & 0.19232110 & 0.00046253 \\ \mathrm{C} & -5.79932745 & 2.55727315 & -0.00007549 \\ \mathrm{C} & -7.01652053 & 3.24966590 & -0.00020242 \\ \mathrm{C} & -8.23111774 & 2.55629148 & -0.00039542 \\ \mathrm{C} & -8.25937876 & 1.15554772 & -0.00046538 \\ \mathrm{C} & 2.72687604 & -1.12599947 & 0.00023126 \\ \mathrm{C} & 3.39233683 & 0.19210395 & 0.00021522 \\ \mathrm{Si} & 2.04033997 & 1.50329575 & 0.00054160 \\ \mathrm{Si} & 4.07656401 & -2.46013176 & -0.00001297 \\ \mathrm{C} & 5.42130100 & -1.16908881 & -0.00020059 \\ \mathrm{C} & 4.75974350 & 0.15690517 & -0.00001617 \\ \mathrm{C} & 6.77358388 & -0.99151850 & -0.00040187 \\ \mathrm{C} & 7.05306139 & 0.45997842 & -0.00033780 \\ \mathrm{C} & 5.81847922 & 1.16546514 & -0.00013470 \\ \mathrm{C} & 8.25937876 & 1.15554783 & -0.00046438 \\ \mathrm{C} & 8.23111763 & 2.55629160 & -0.00038921\end{array}$

$\begin{array}{crrr}\mathrm{C} & 7.01652043 & 3.24966598 & -0.00019131 \\ \mathrm{C} & 5.79932734 & 2.55727315 & -0.00006389 \\ \mathrm{C} & -7.84489841 & -2.03626732 & -0.00064302 \\ \mathrm{C} & 7.84489851 & -2.03626722 & -0.00064251 \\ \mathrm{H} & -4.03437356 & -3.34030831 & 1.20125084 \\ \mathrm{H} & -4.03397446 & -3.34033096 & -1.20121466 \\ \mathrm{H} & -2.04332869 & 2.37902905 & 1.20473248 \\ \mathrm{H} & -2.04312087 & 2.37959458 & -1.20321886 \\ \mathrm{H} & -0.00000151 & -3.31209390 & -1.20364972 \\ \mathrm{H} & 0.00000151 & -3.31174239 & 1.20480550 \\ \mathrm{H} & -4.86094527 & 3.10660028 & 0.00008166 \\ \mathrm{H} & -7.01687334 & 4.33615078 & -0.00014692 \\ \mathrm{H} & -9.16540112 & 3.1147350 & -0.00049769 \\ \mathrm{H} & -9.21002251 & 0.62823254 & -0.00063091 \\ \mathrm{H} & 2.04332966 & 2.37903664 & 1.20471973 \\ \mathrm{H} & 2.04311972 & 2.37958690 & -1.20323166 \\ \mathrm{H} & 4.03397498 & -3.34031743 & -1.20124025 \\ \mathrm{H} & 4.03437330 & -3.34032204 & 1.20122524 \\ \mathrm{H} & 9.21002246 & 0.62823268 & -0.00063157 \\ \mathrm{H} & 9.16540102 & 3.11147366 & -0.00049029 \\ \mathrm{H} & 7.01687312 & 4.33615085 & -0.00013285 \\ \mathrm{H} & 4.86094516 & 3.10660028 & 0.00009458 \\ \mathrm{H} & -8.49377973 & -1.93939904 & -0.88166305 \\ \mathrm{H} & -7.42190428 & -3.04514310 & -0.00063552 \\ \mathrm{H} & -8.49407348 & -1.93950836 & 0.88017227 \\ \mathrm{H} & 7.42190444 & -3.04514303 & -0.00061407 \\ \mathrm{H} & 8.49376682 & -1.93941204 & -0.88167363 \\ \mathrm{H} & 8.49408650 & -1.93949503 & 0.88016170\end{array}$




\section{X. ${ }^{1} \mathrm{H}$ and ${ }^{13} \mathrm{C}$ NMR Spectra}

compound 1a

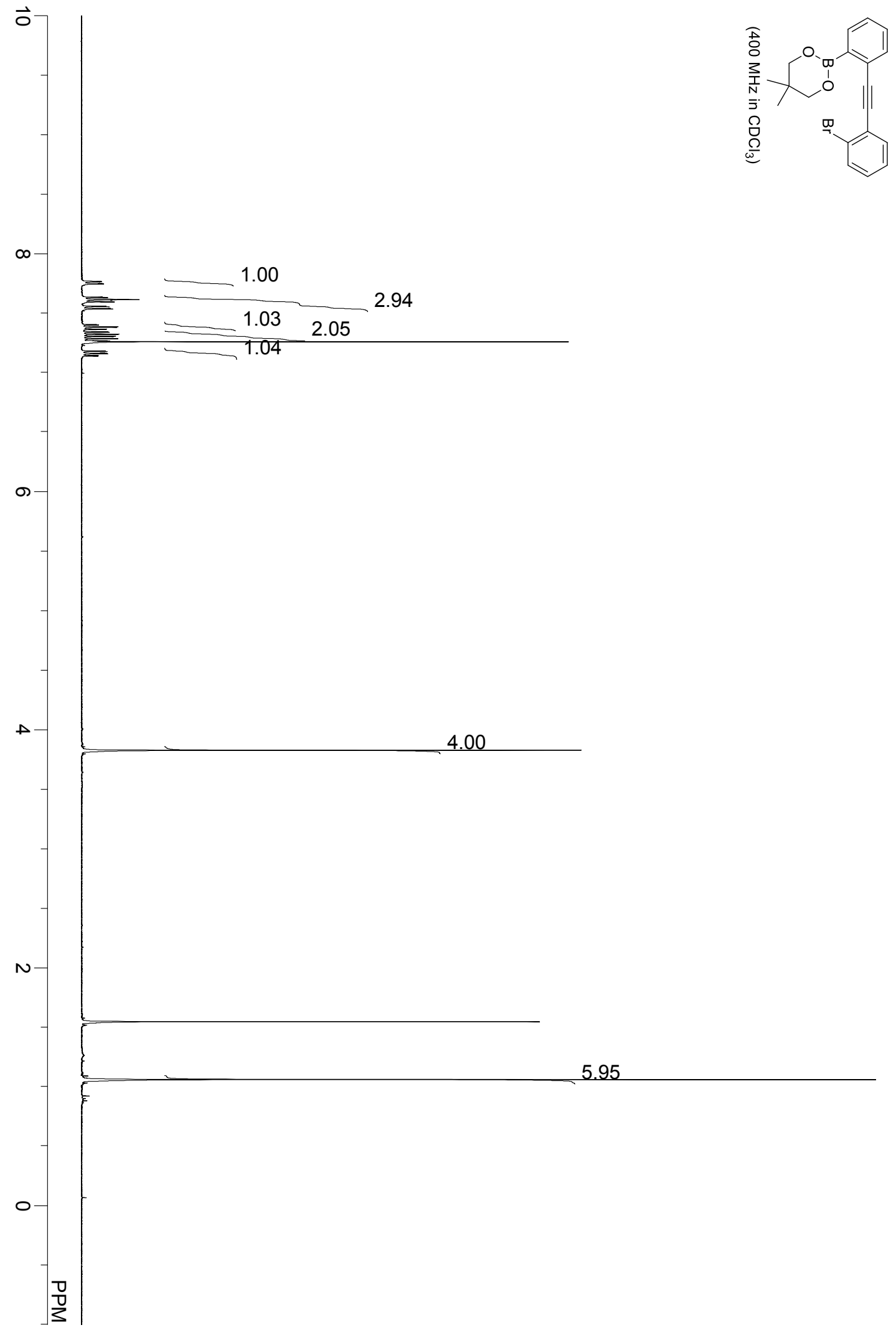


compound 1a

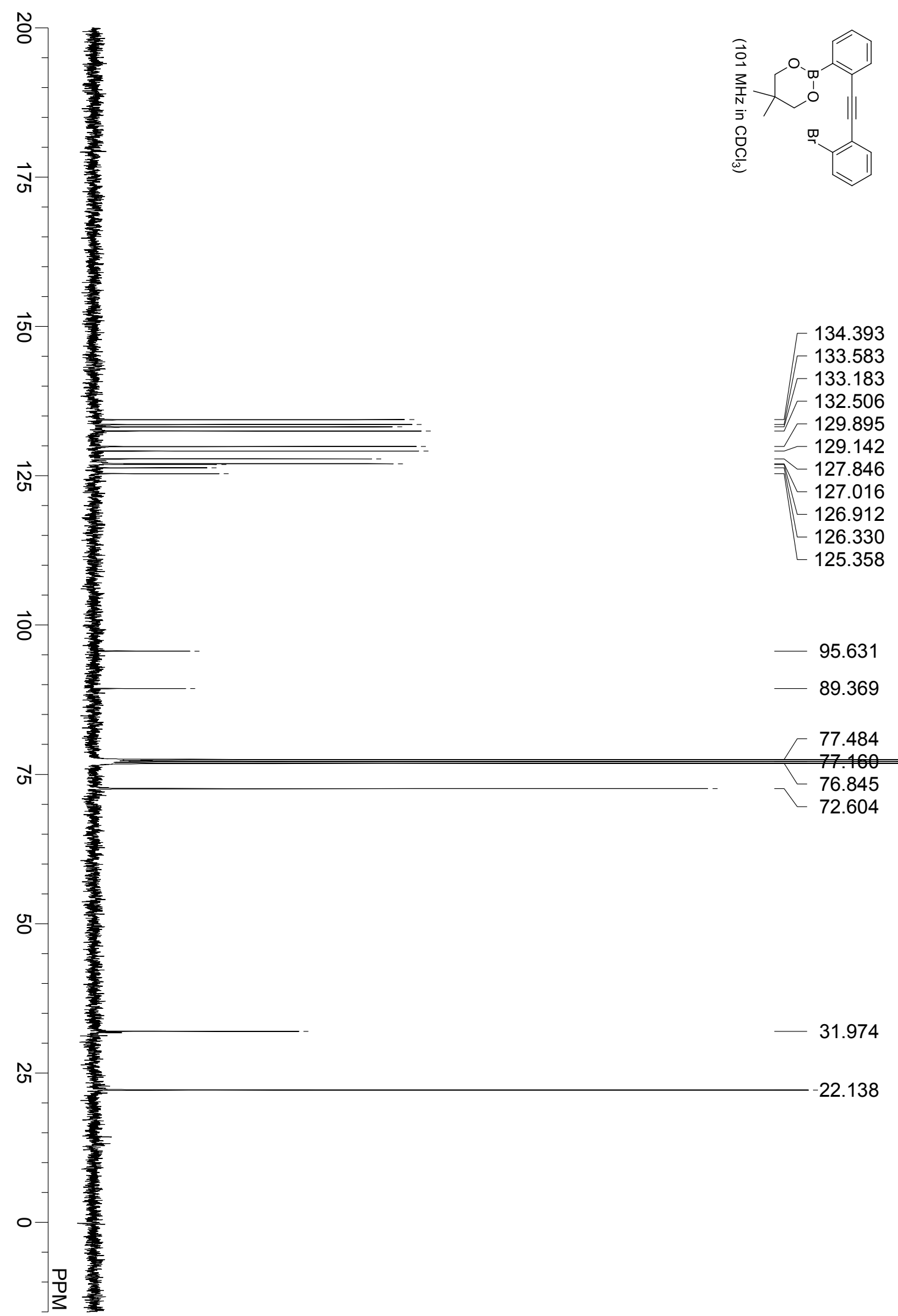


compound $\mathbf{1 b}$

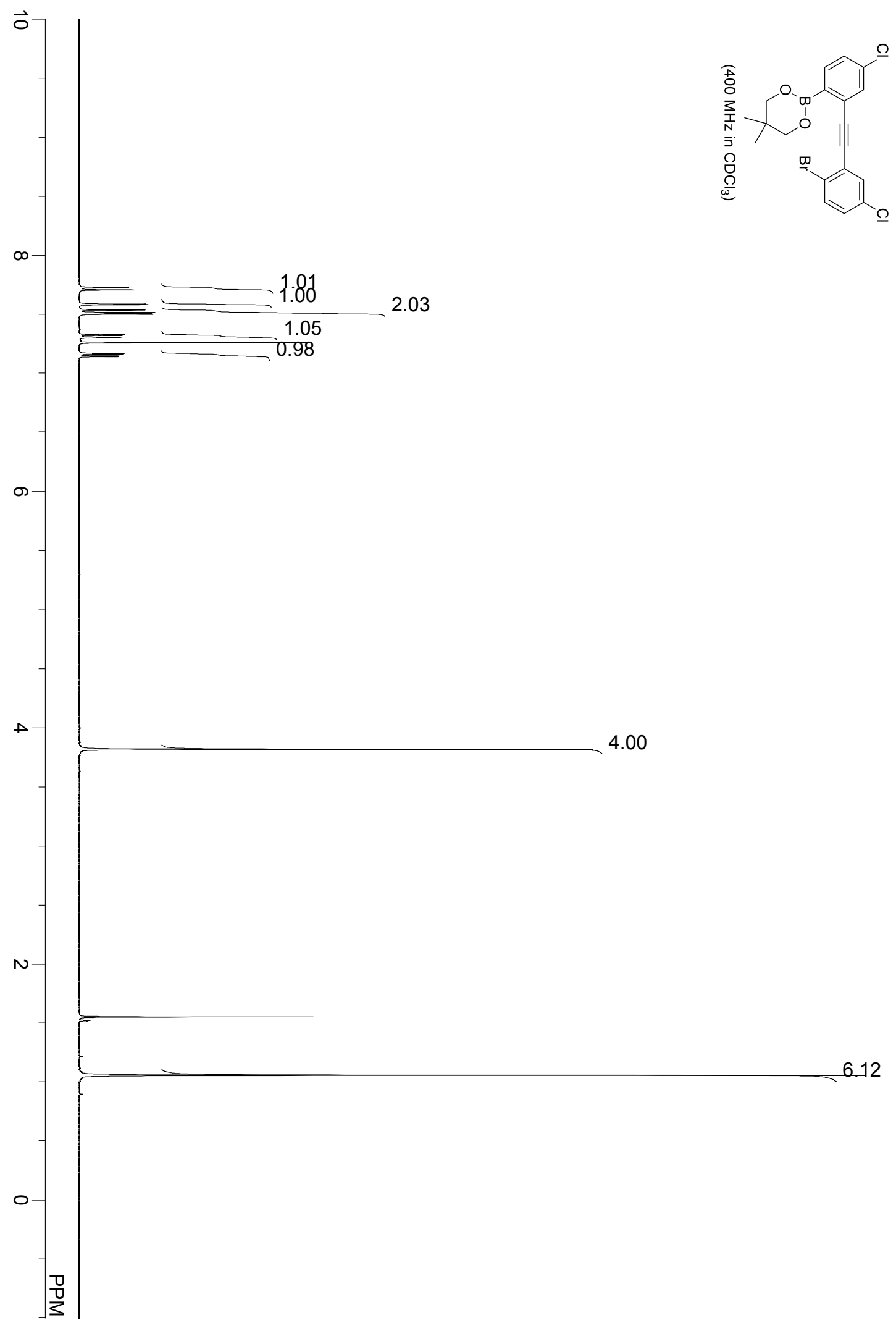


compound $\mathbf{1 b}$

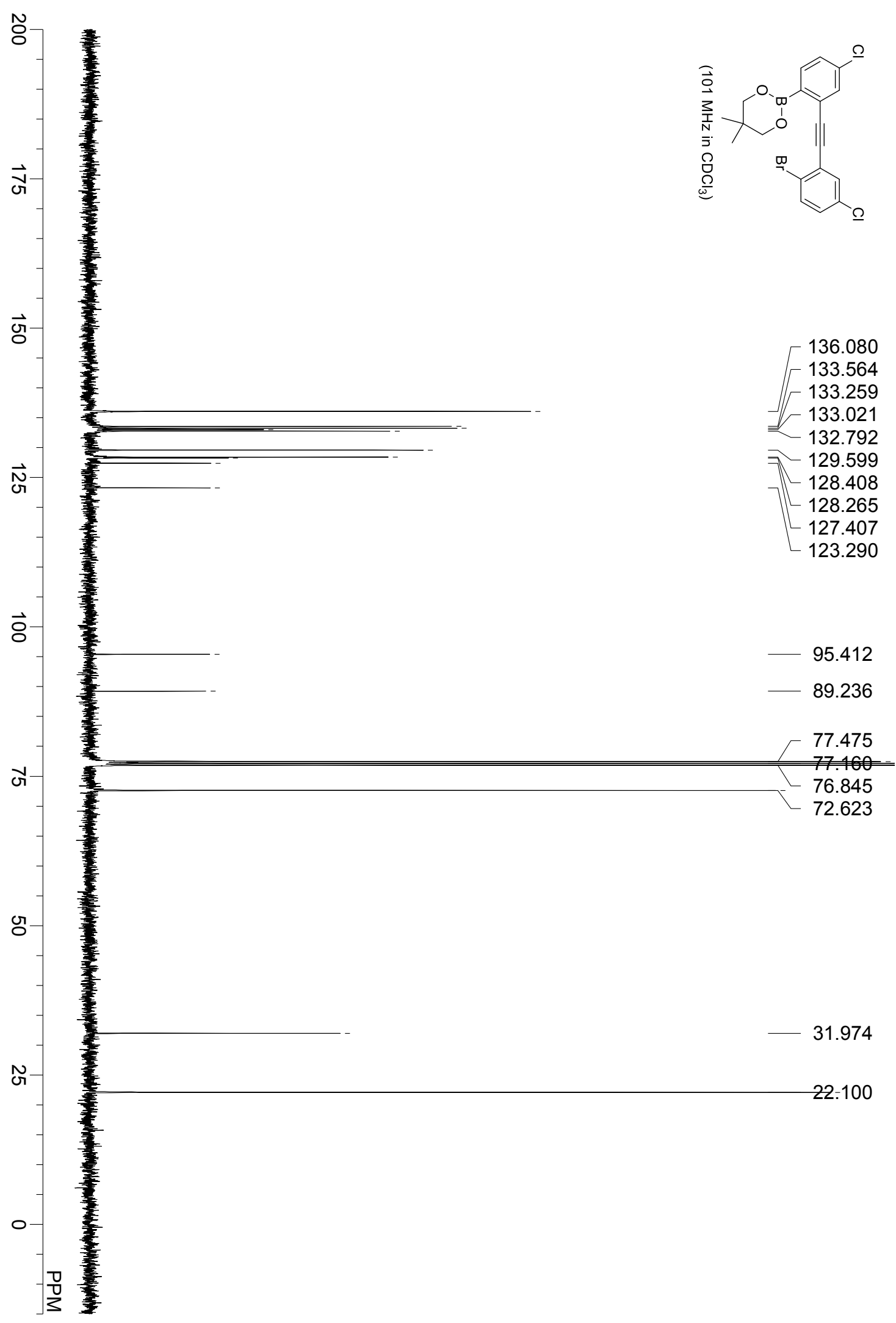


compound $\mathbf{2 a}$

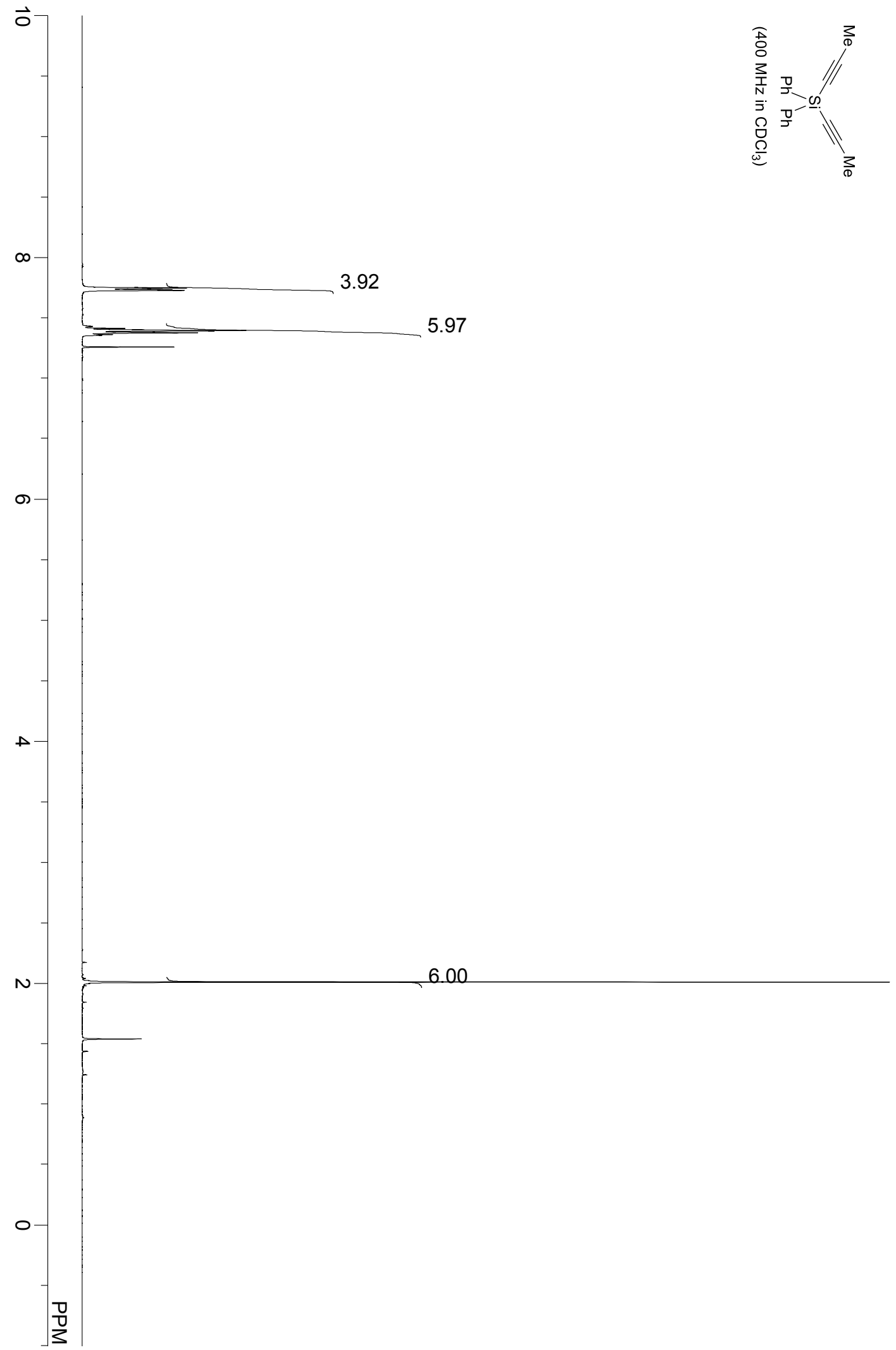


compound 2a

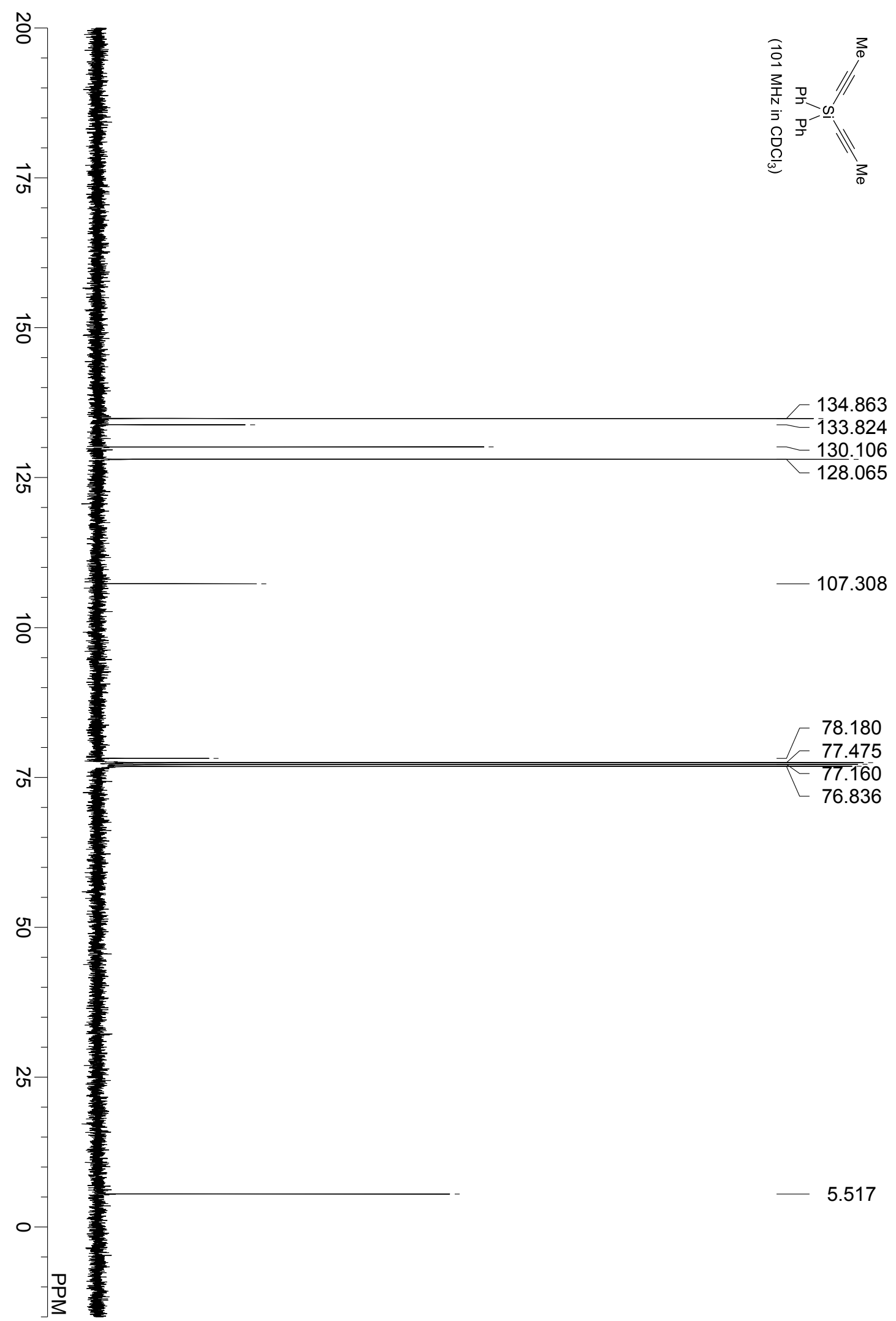


compound $\mathbf{2 b}$

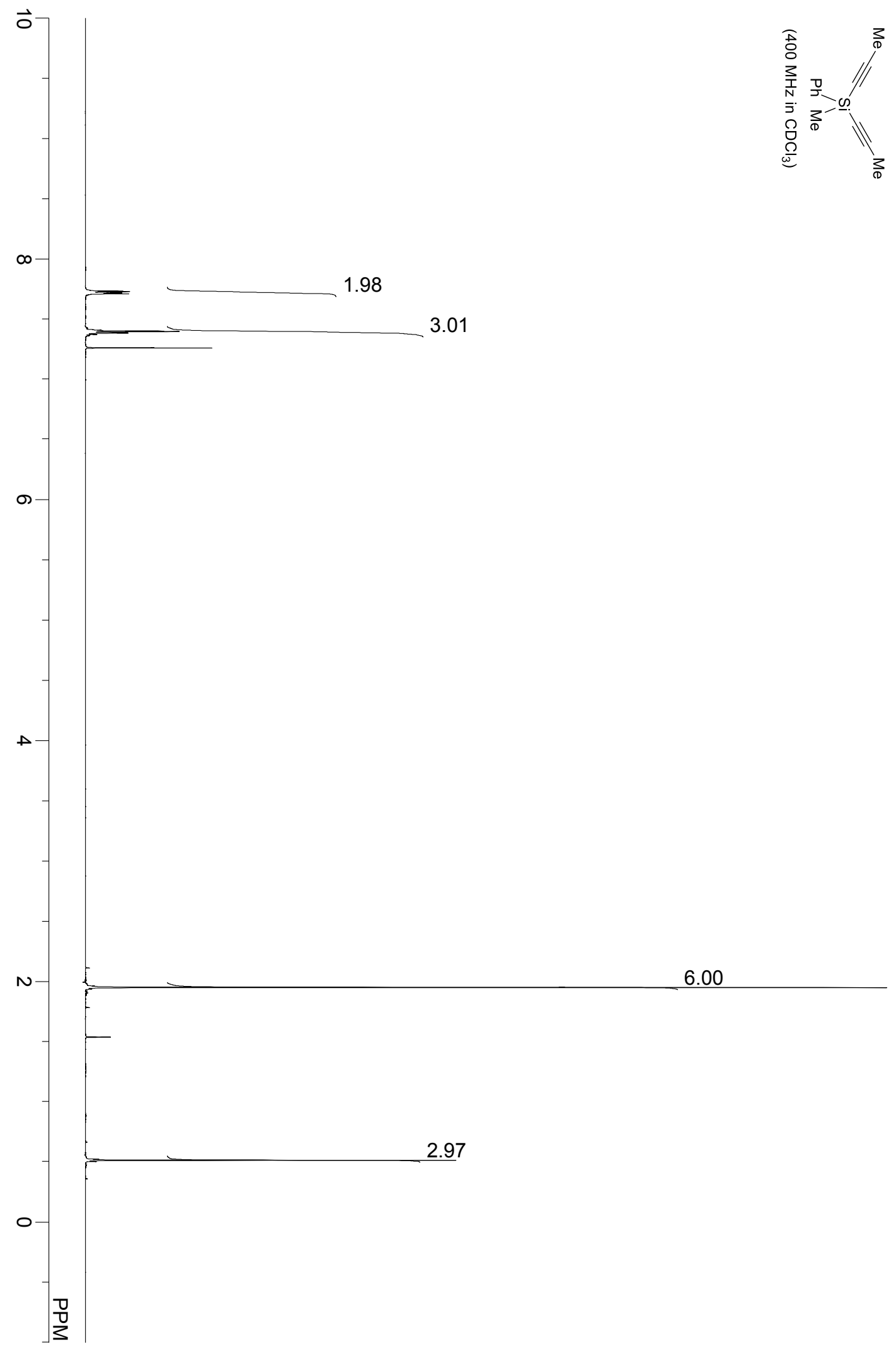


compound $\mathbf{2 b}$

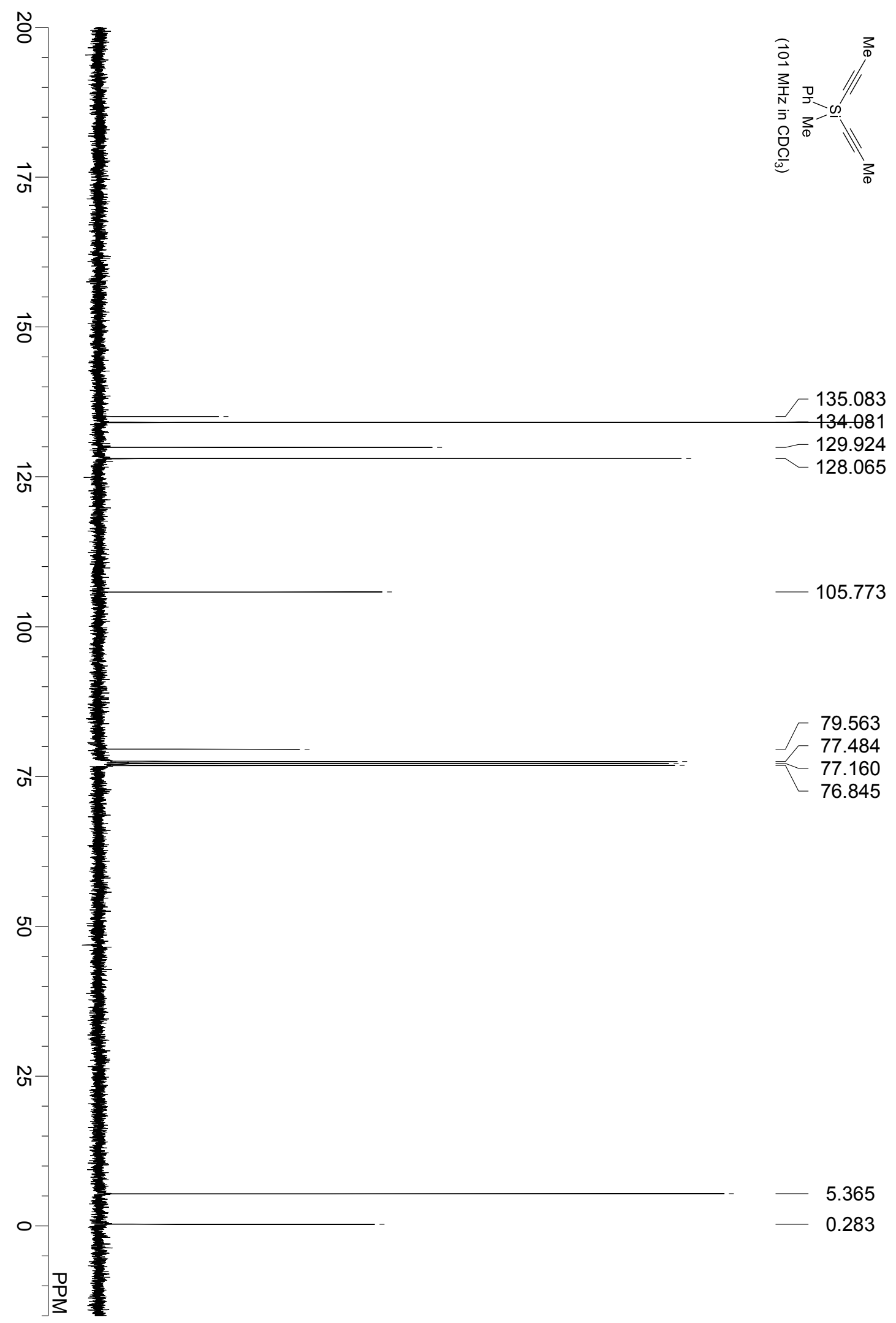


compound $\mathbf{2 c}$

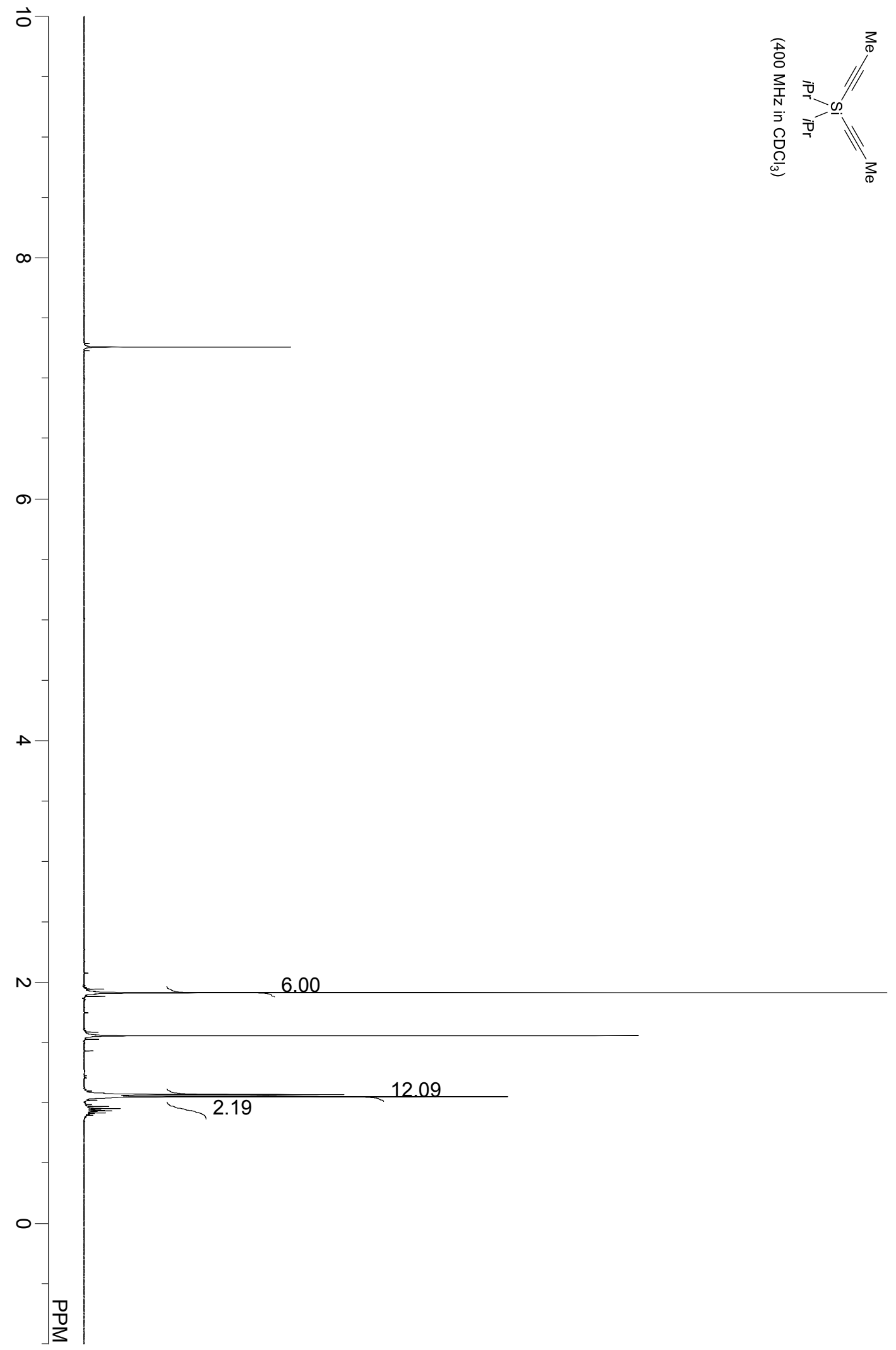


compound 2c

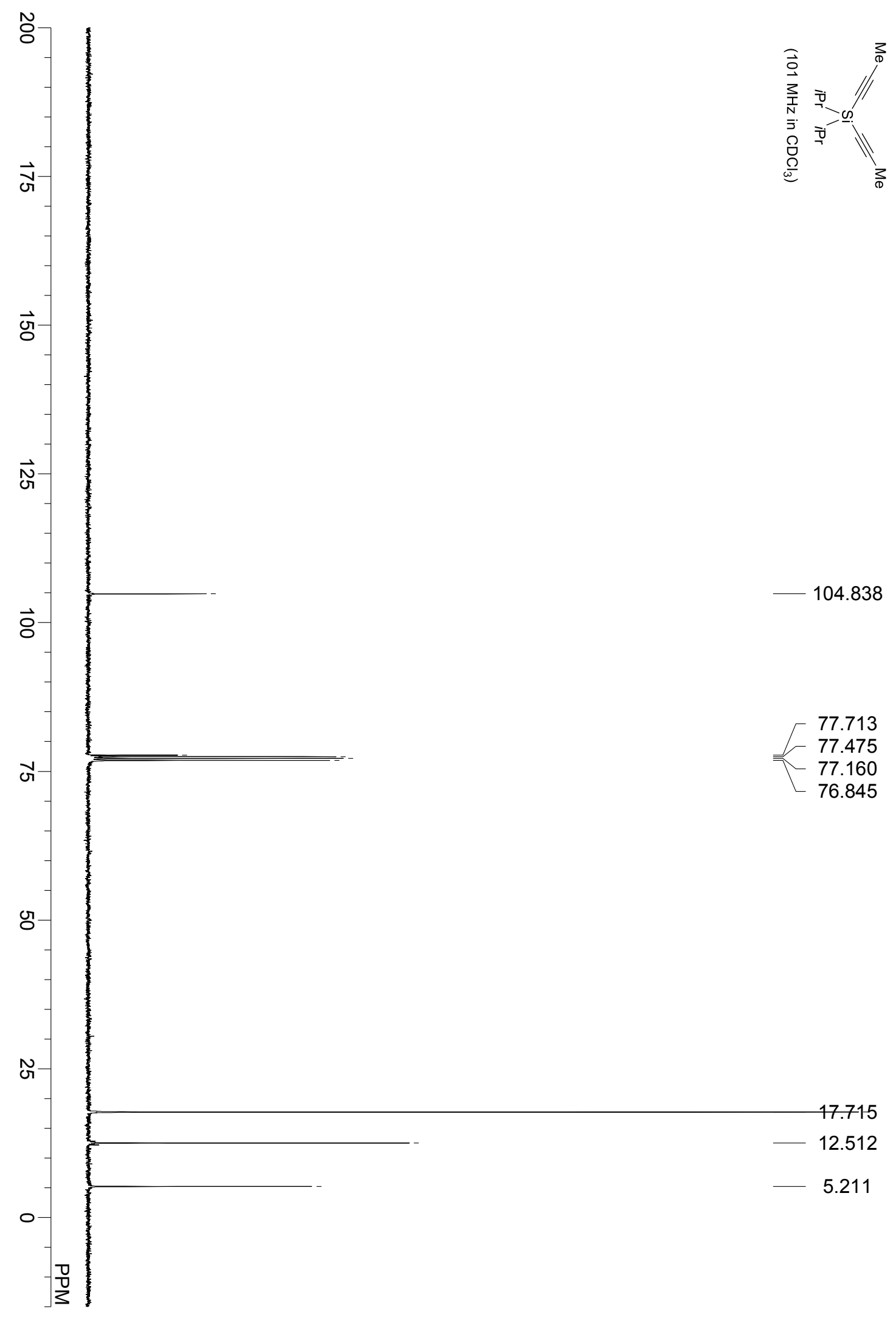


compound 2d

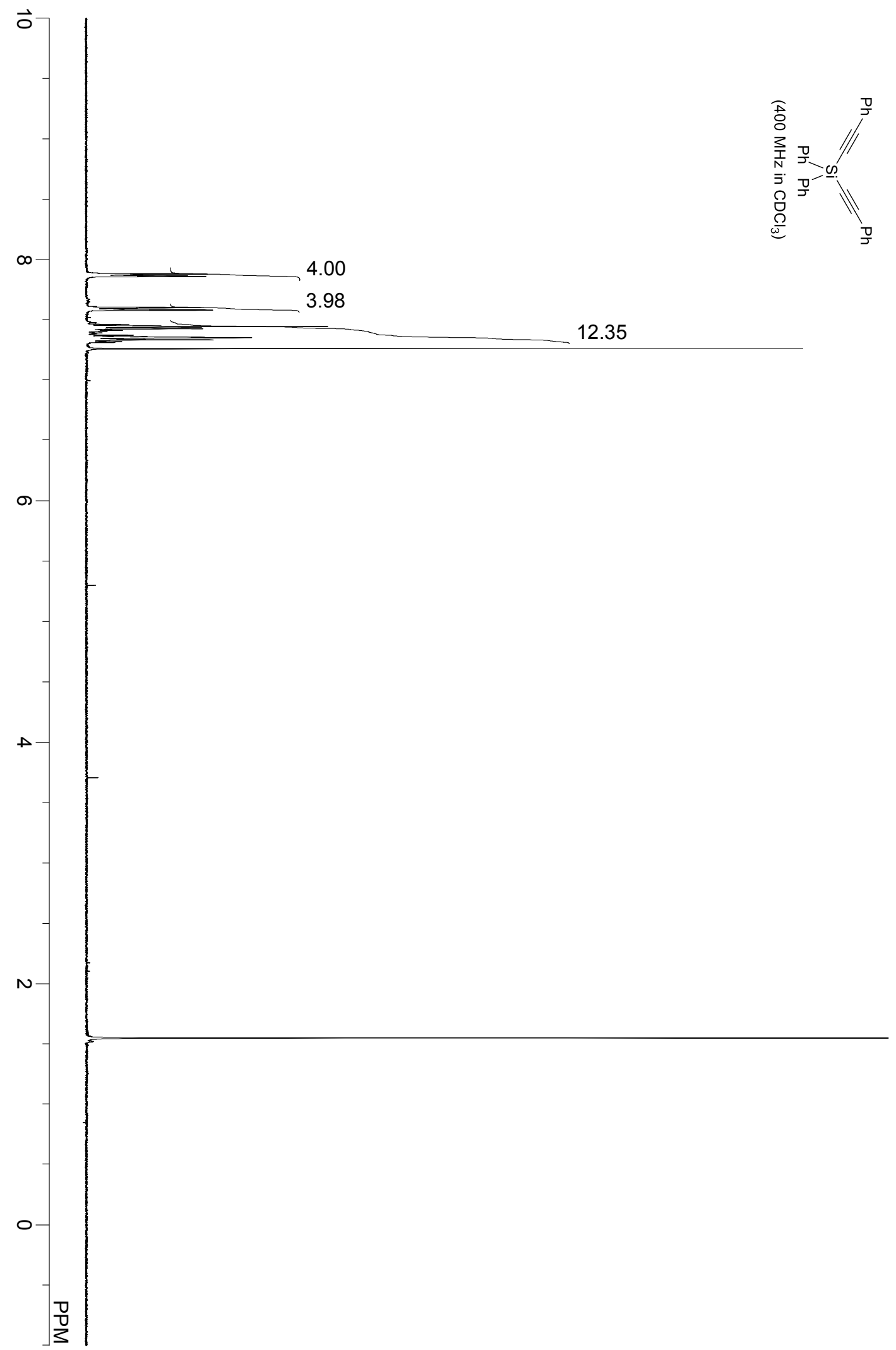


compound 2d

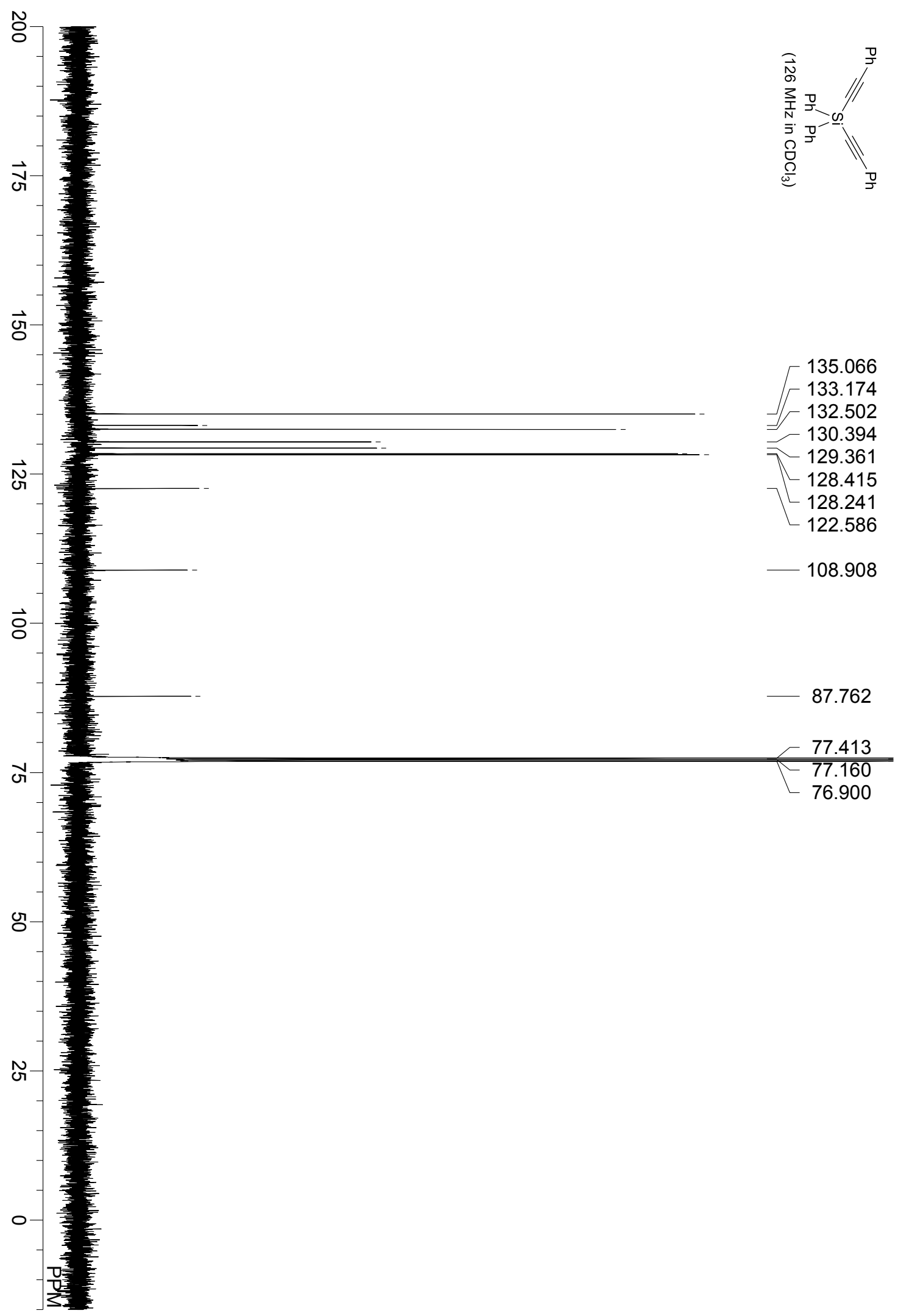


compound 2e

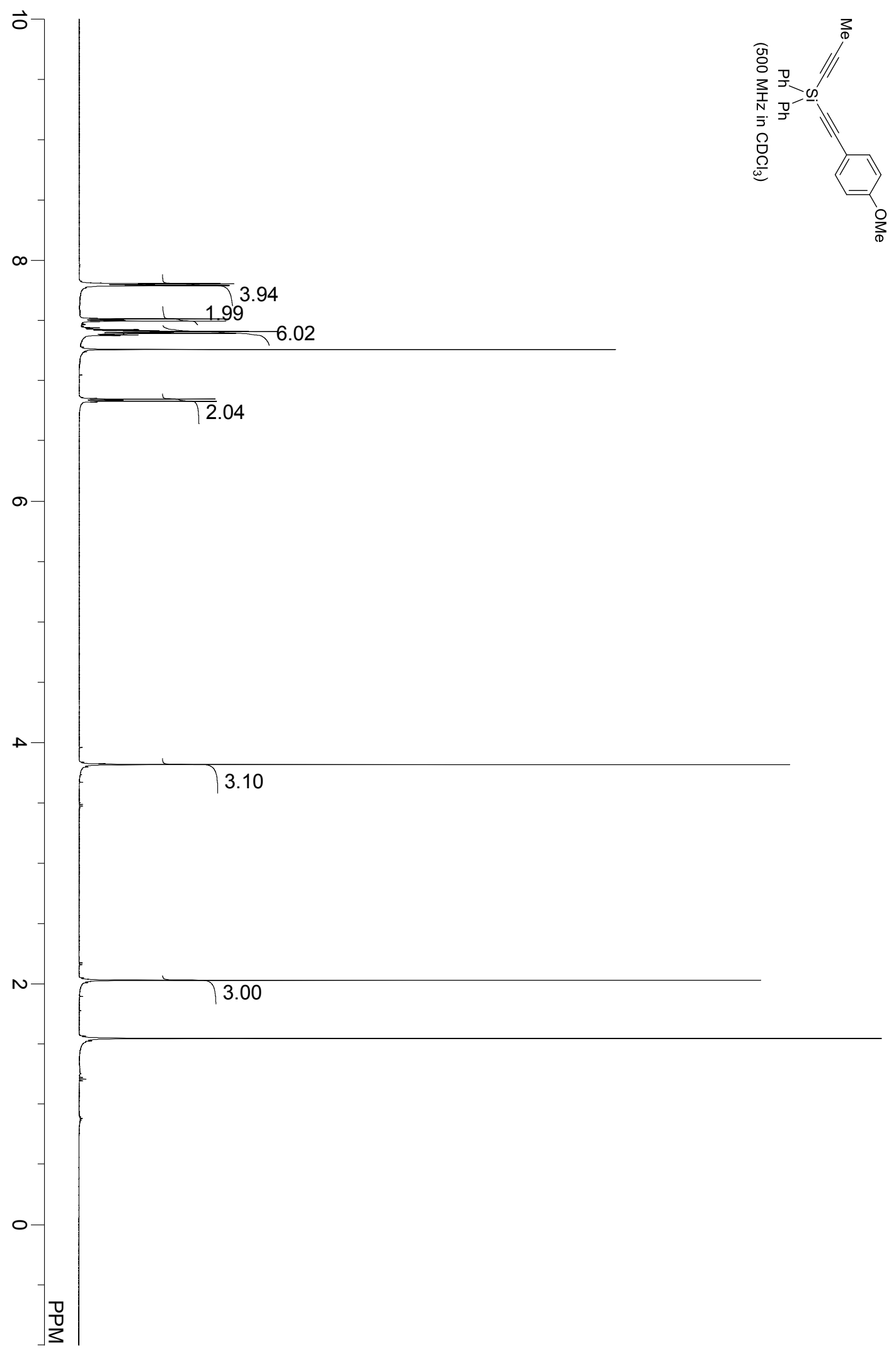


compound 2e

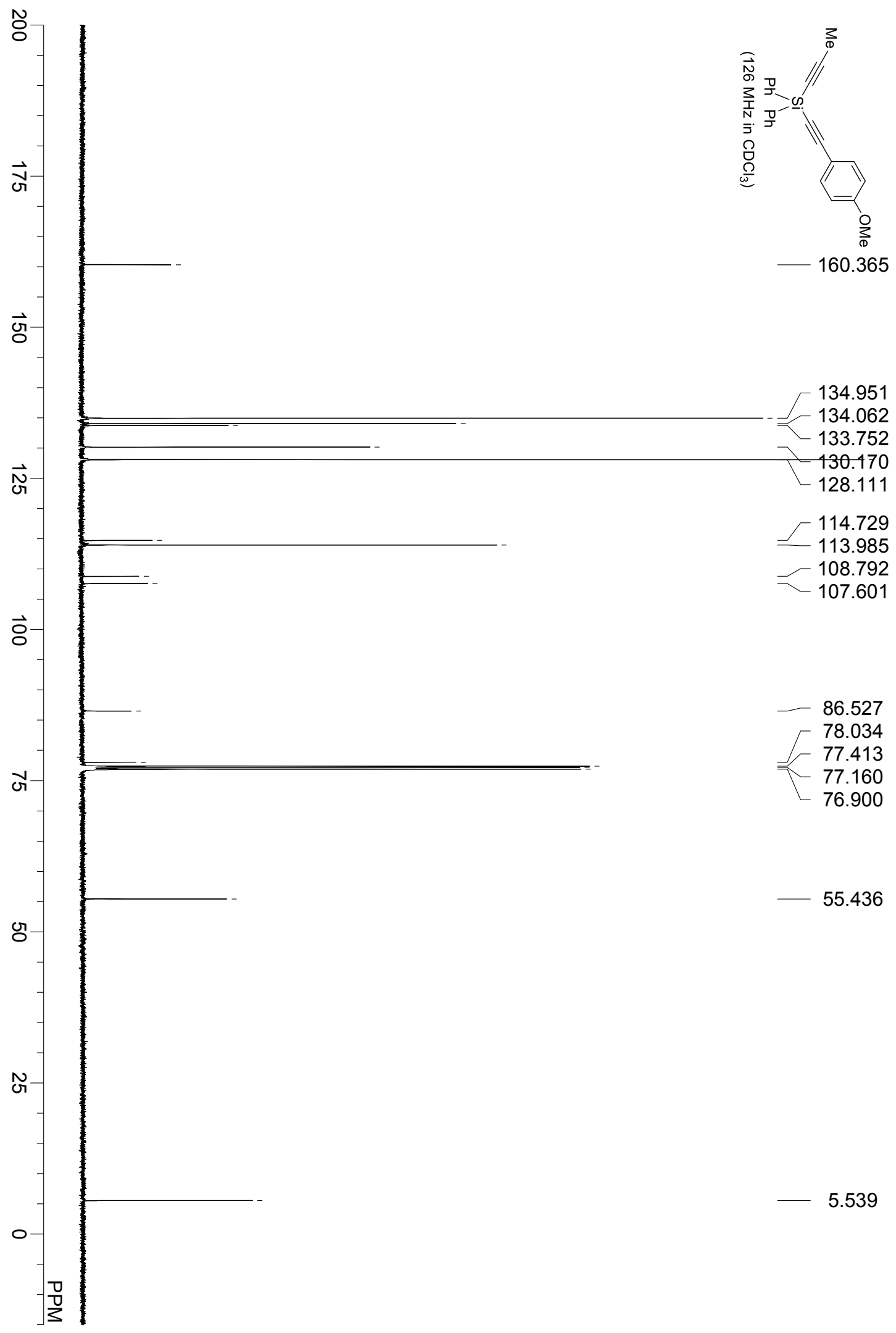


compound $2 \mathbf{f}$

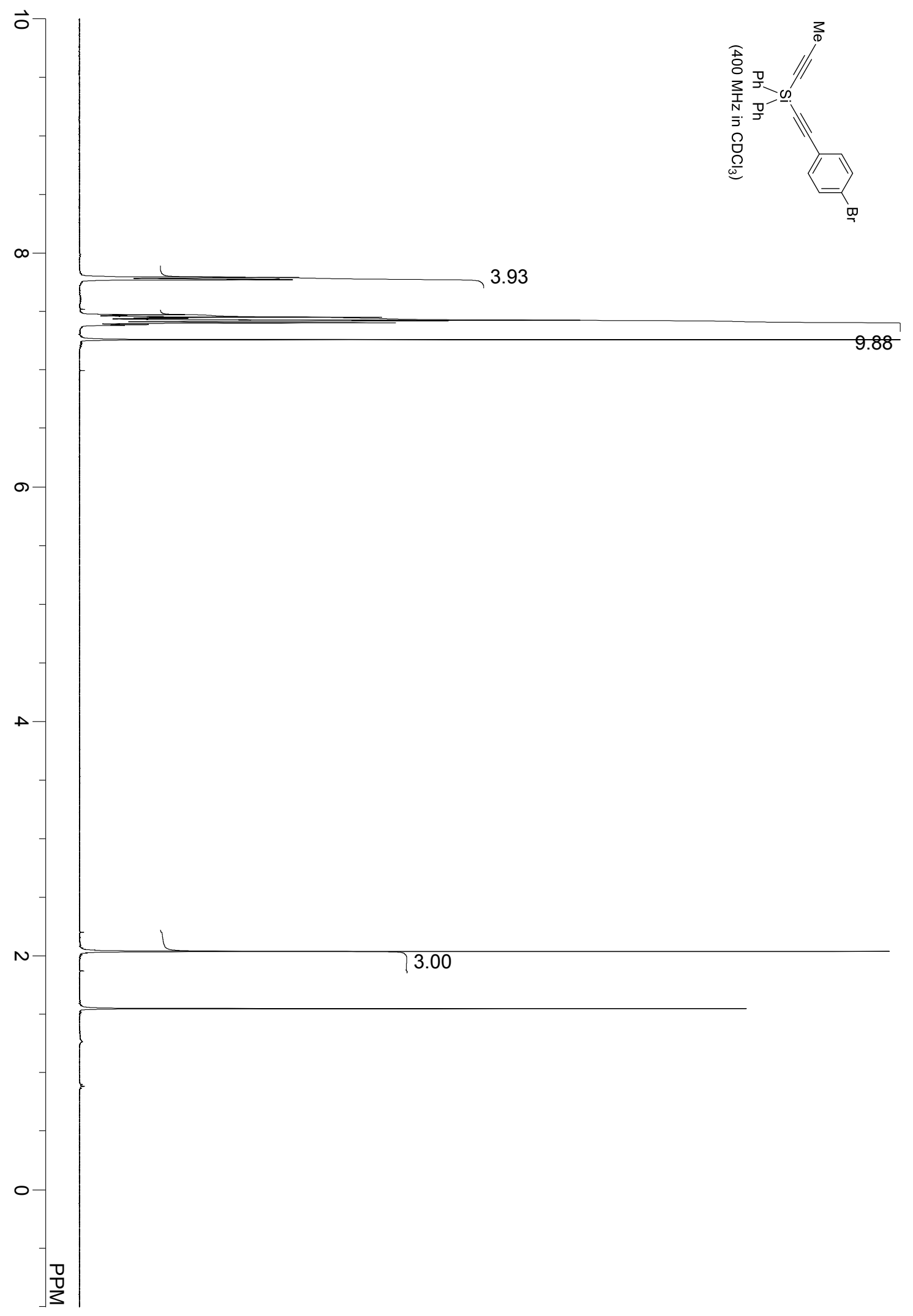


compound $2 f$

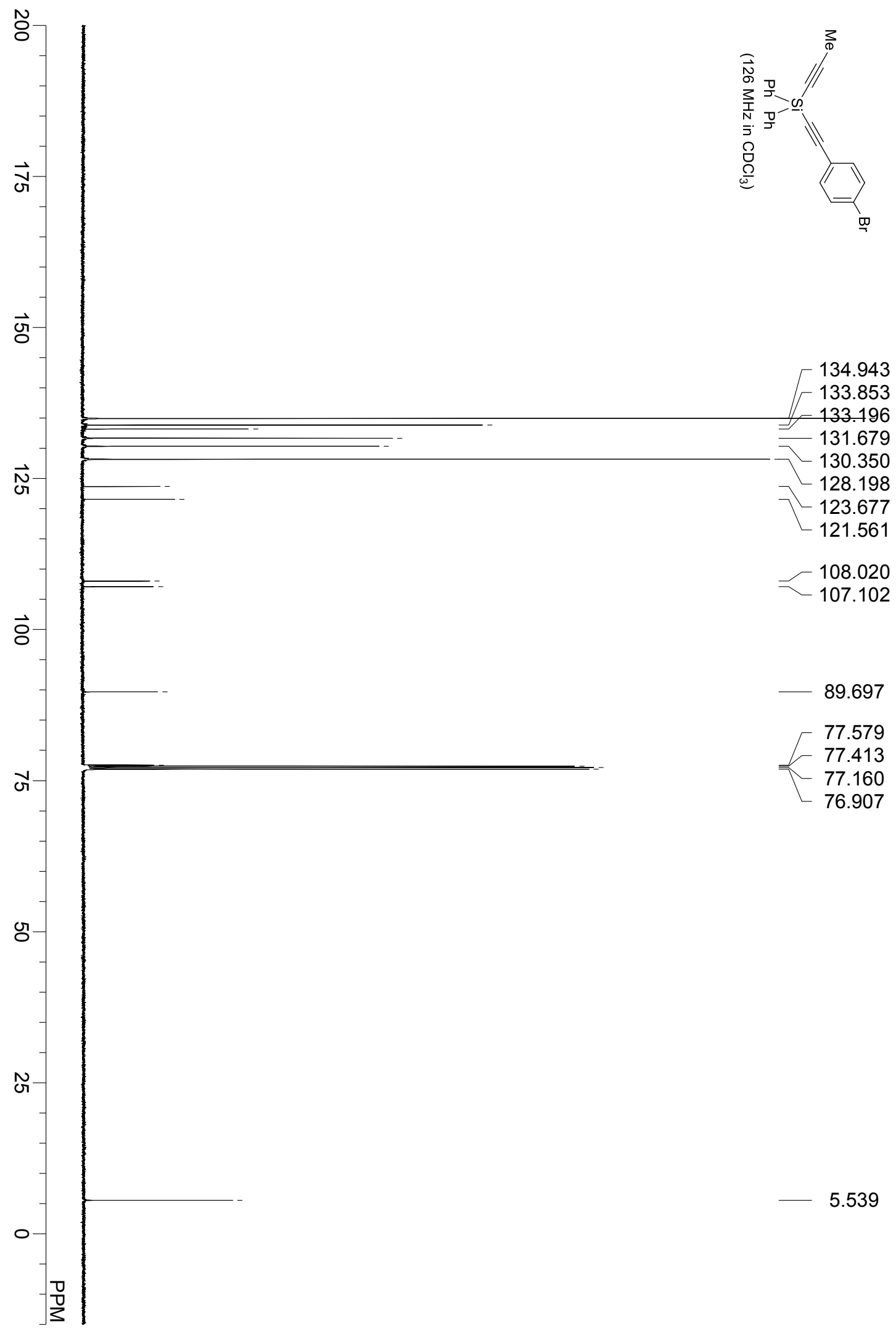


compound 3a

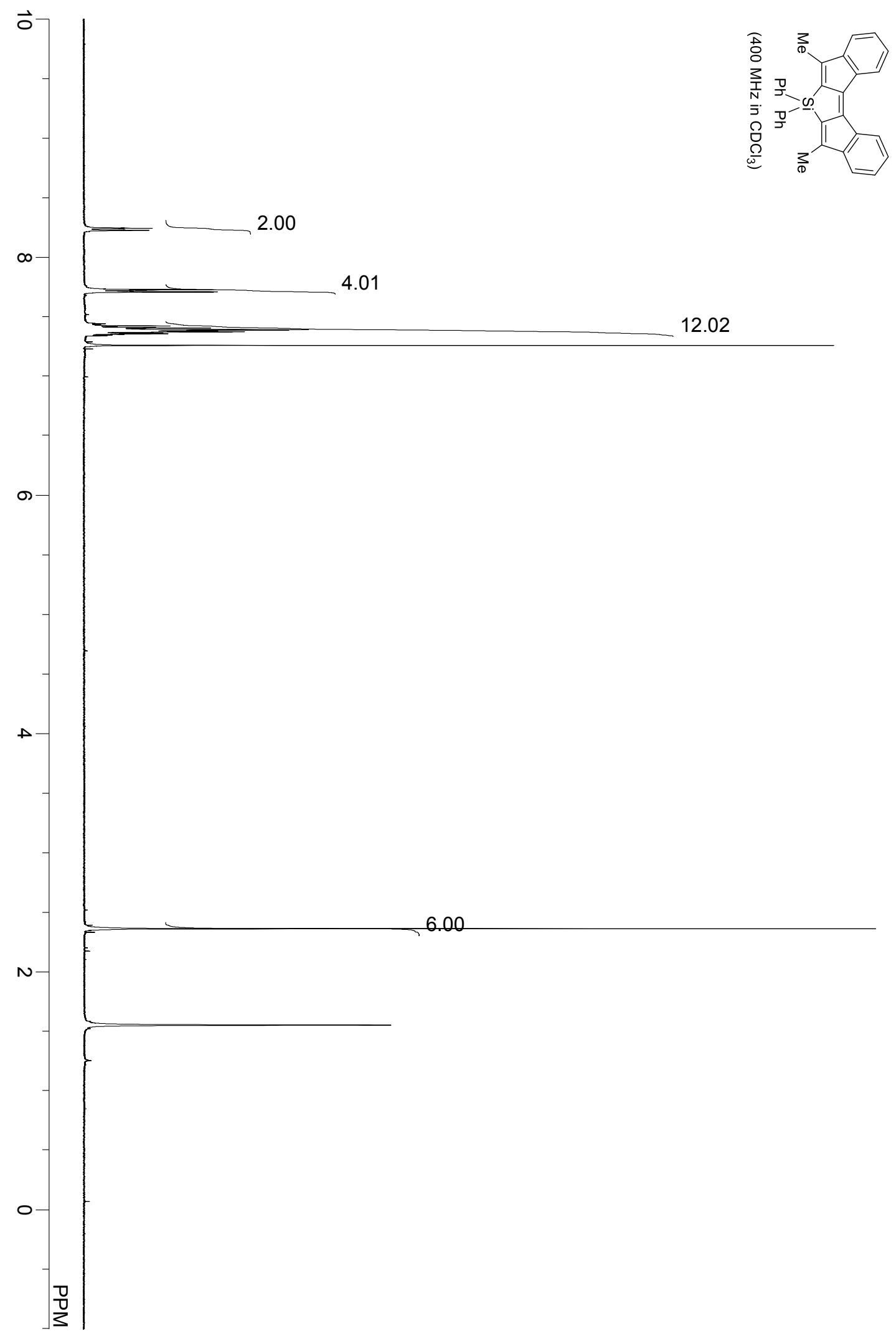


compound 3a

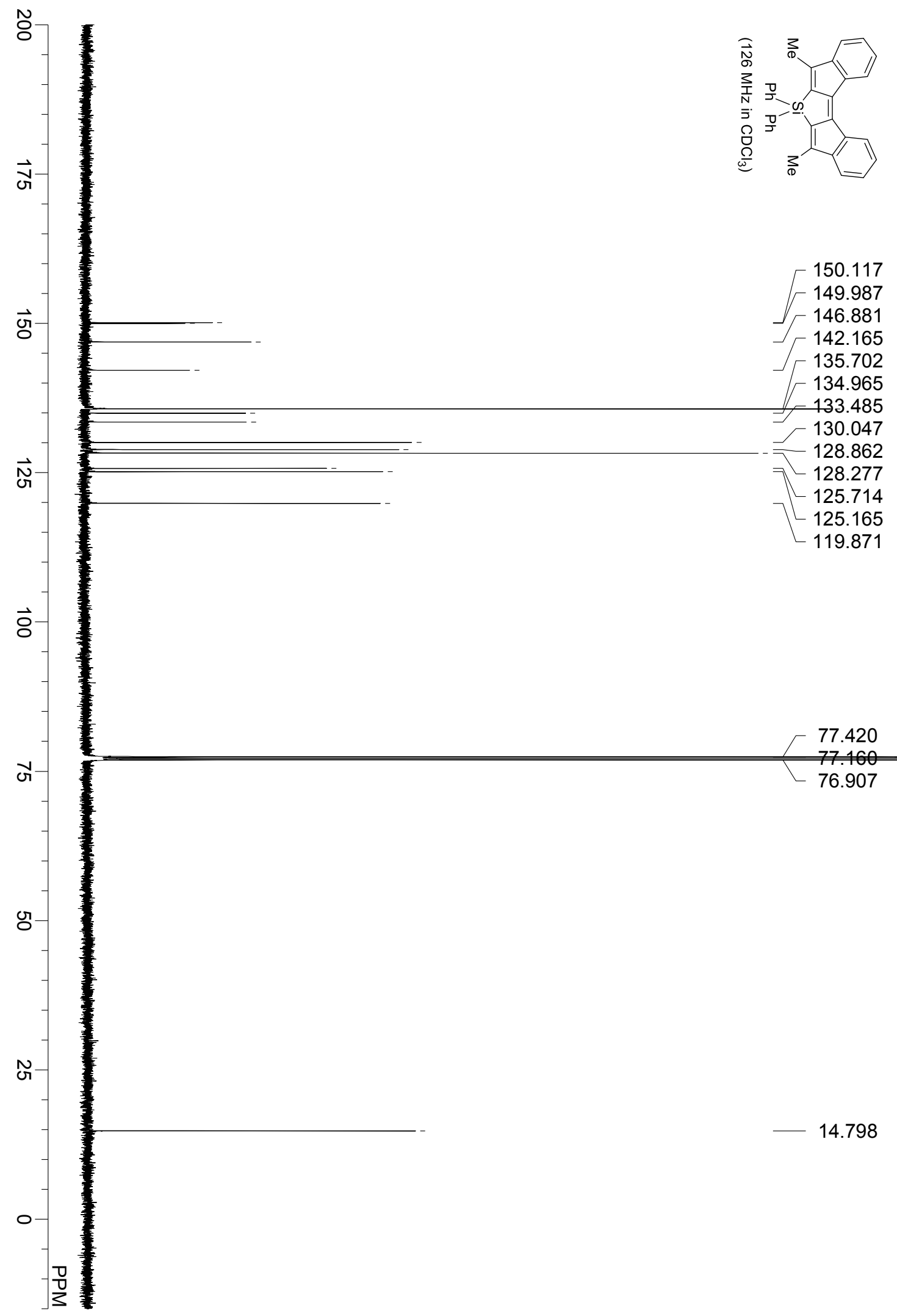


compound $\mathbf{3 b}$

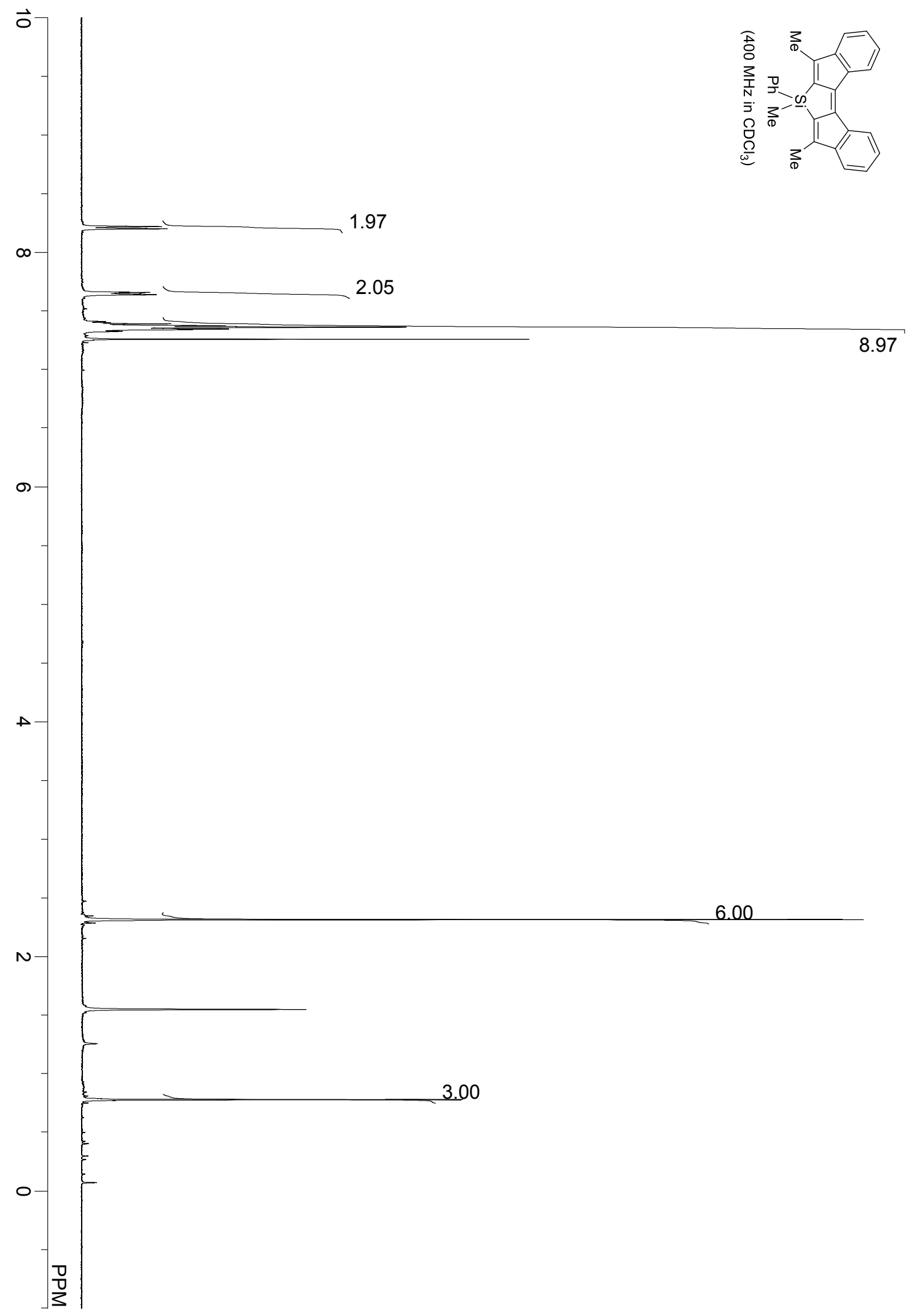


compound $\mathbf{3 b}$

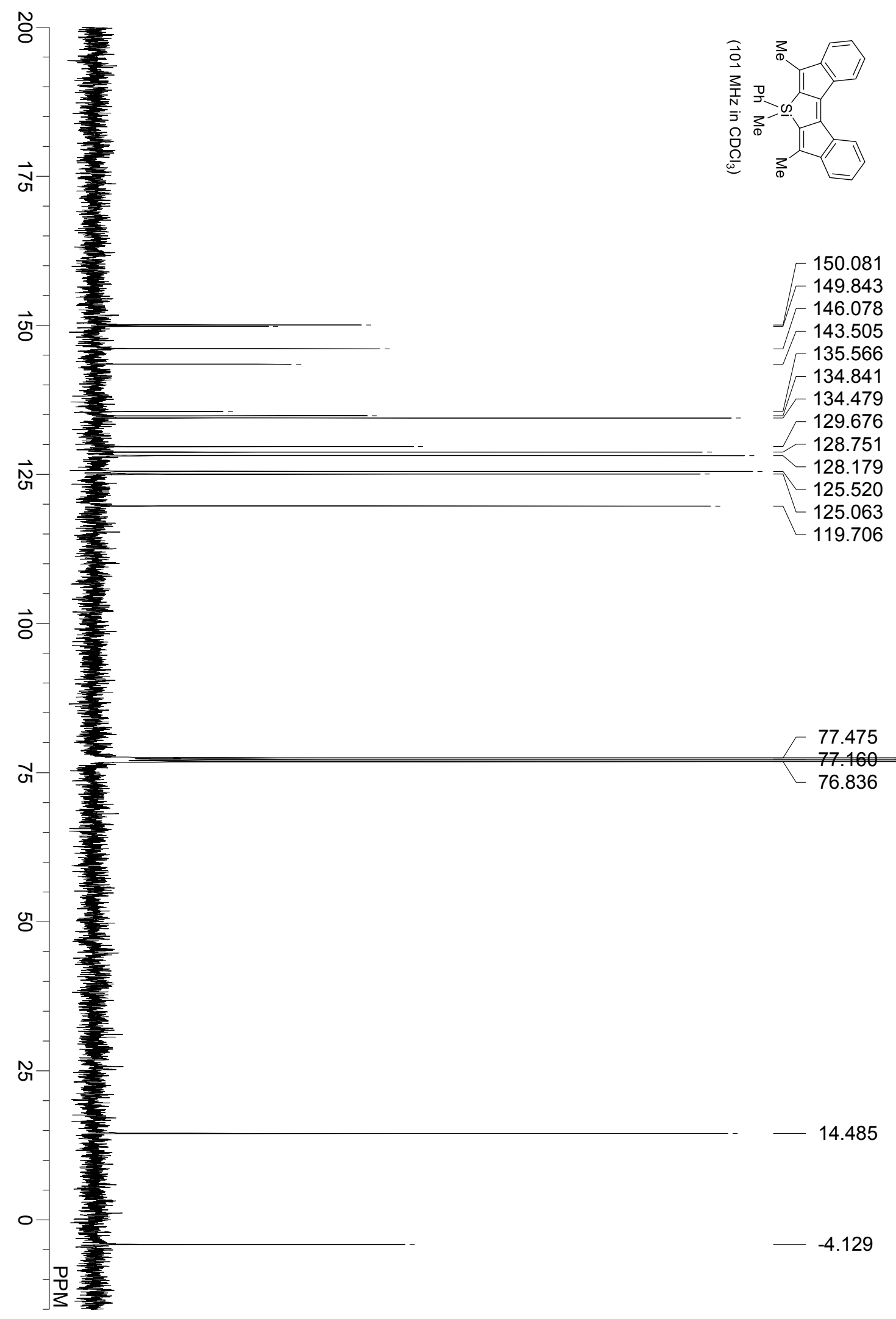


compound 3c

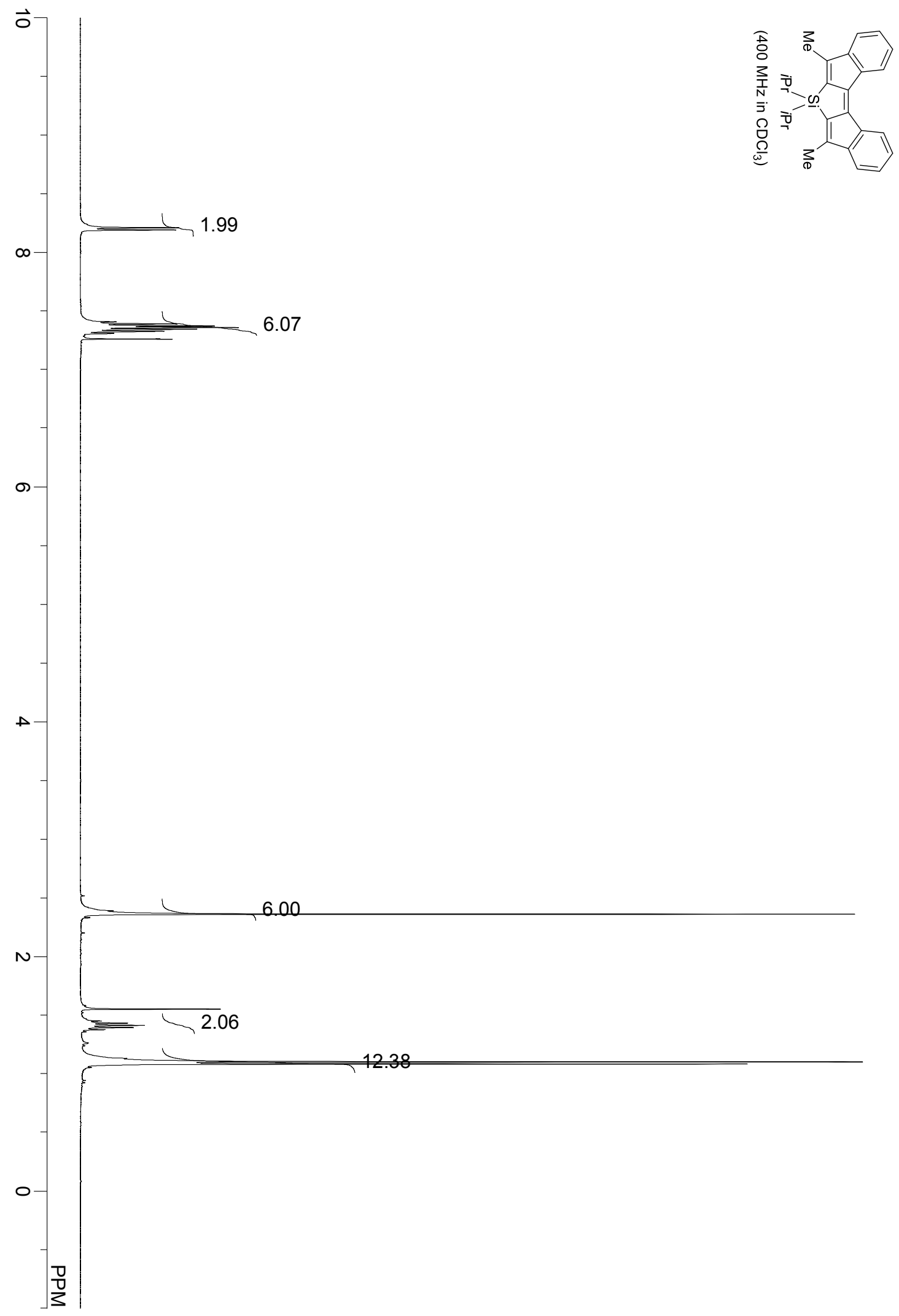


compound 3c

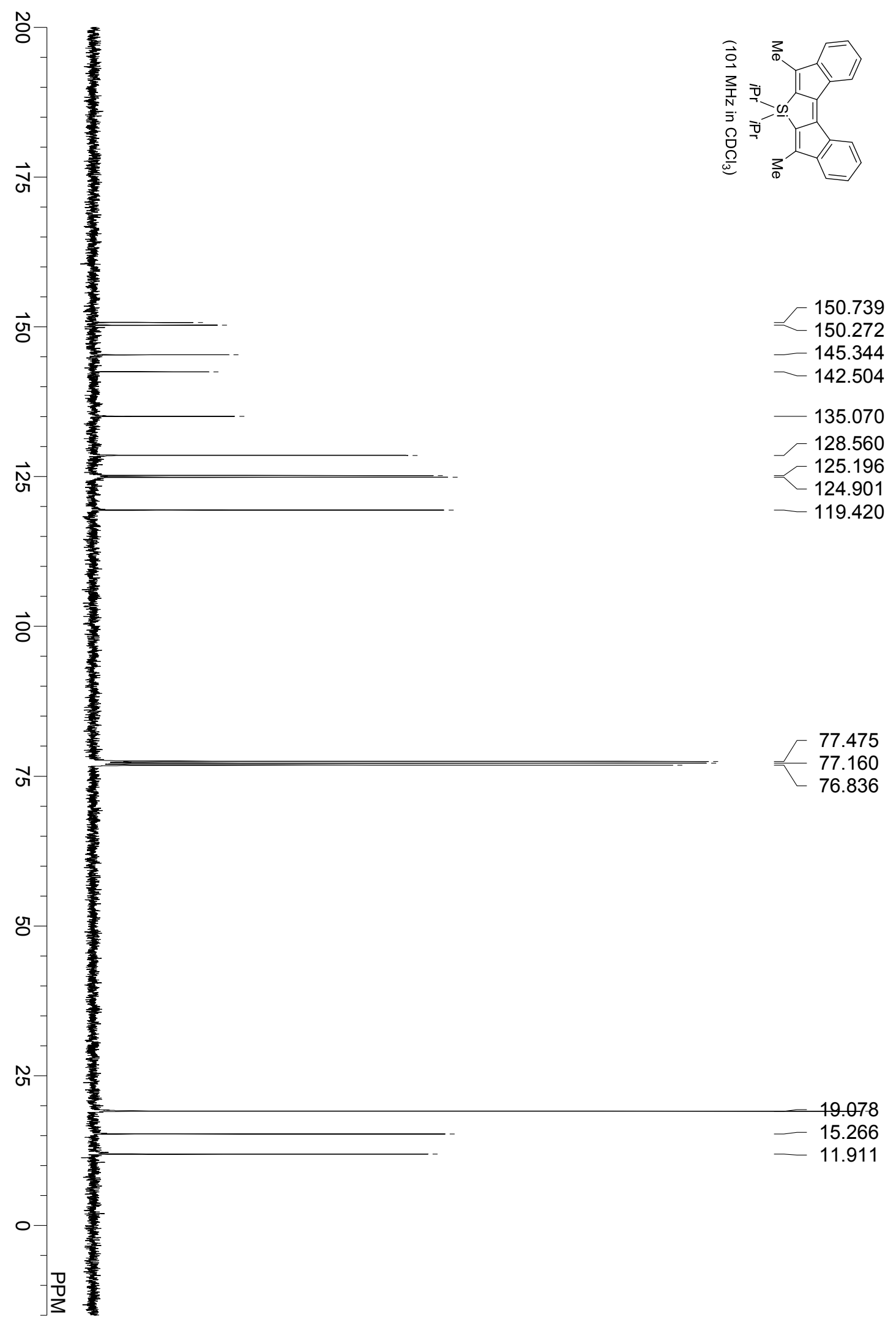


compound 3d

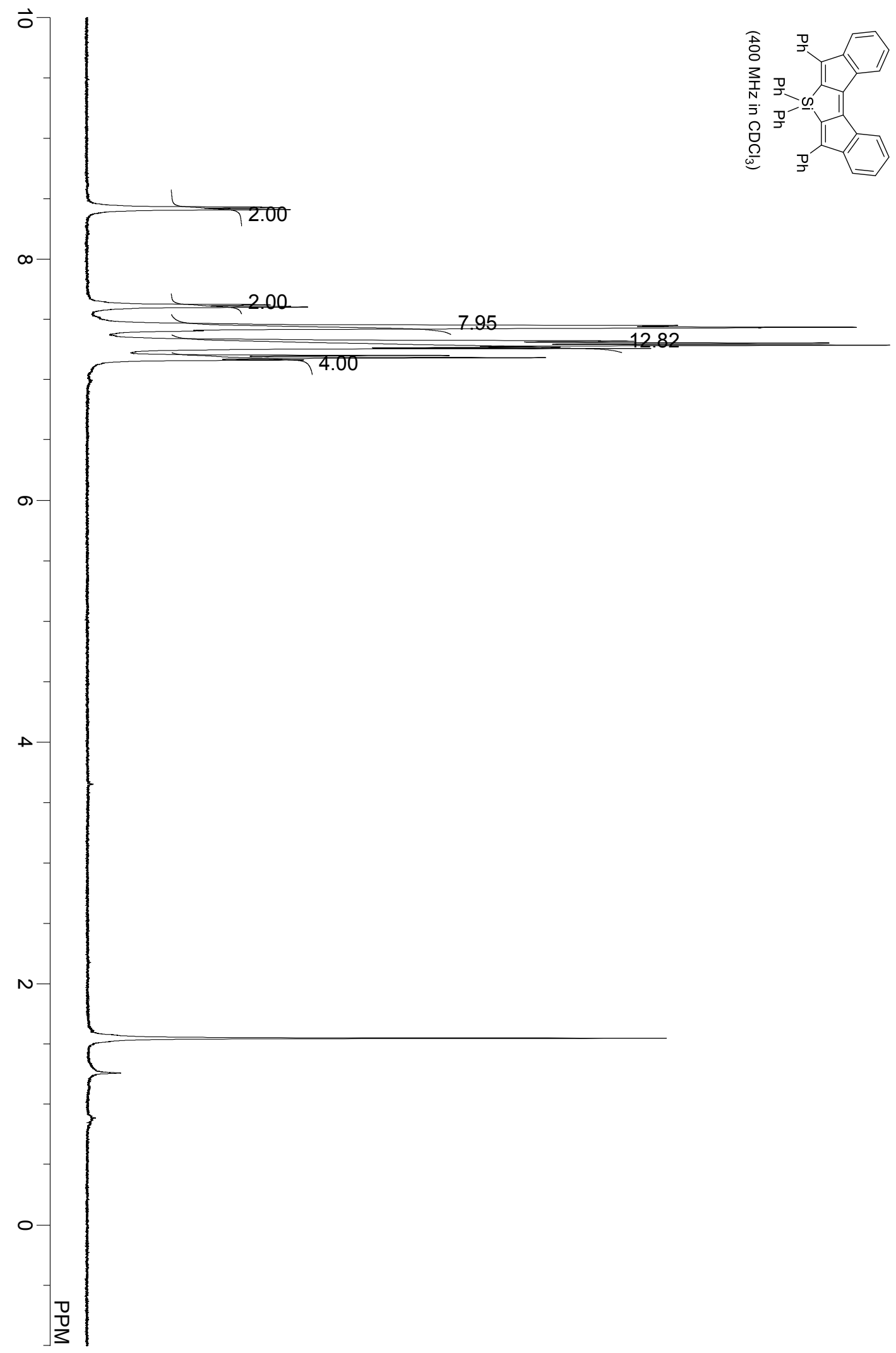


compound 3d

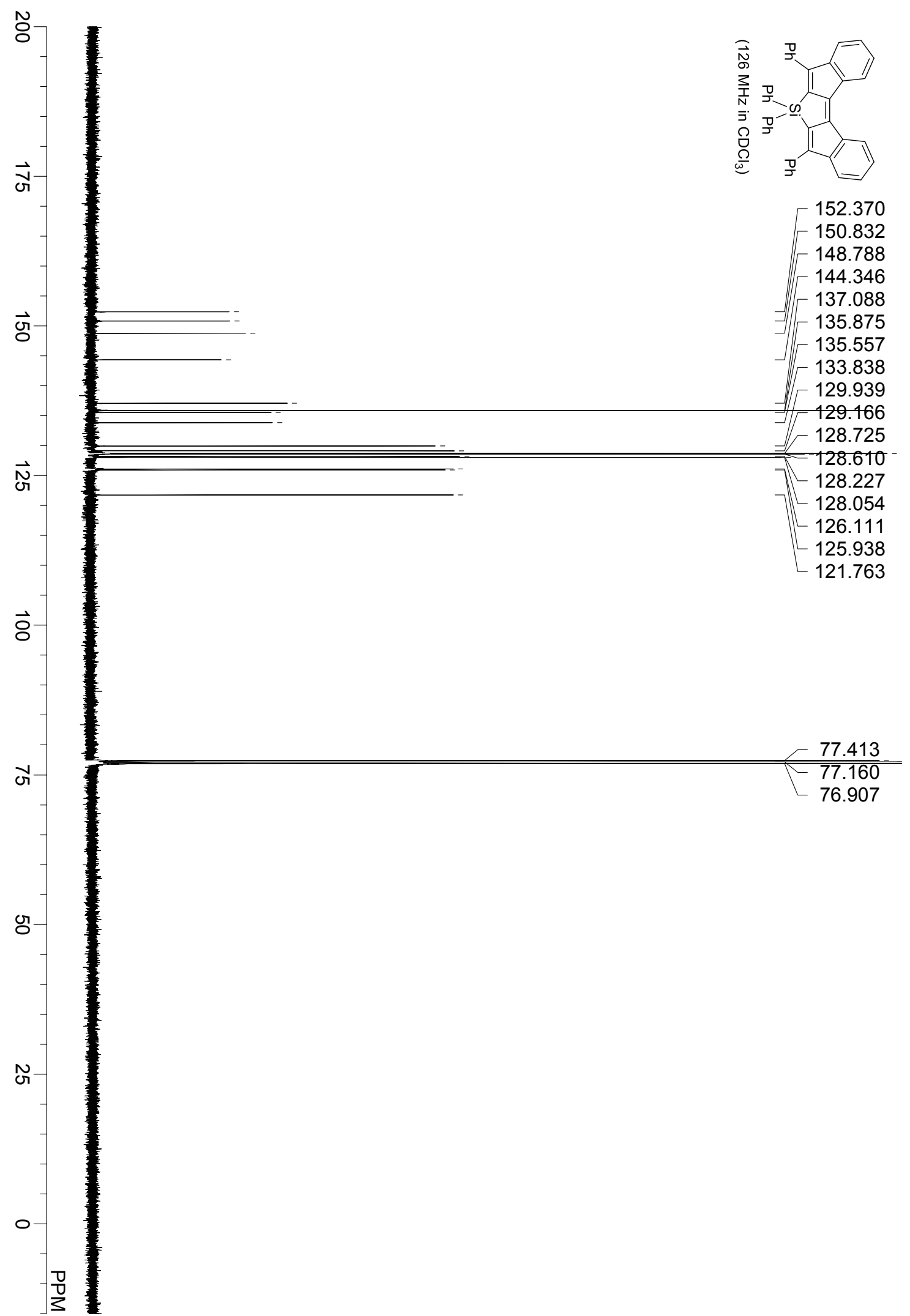


compound 3e

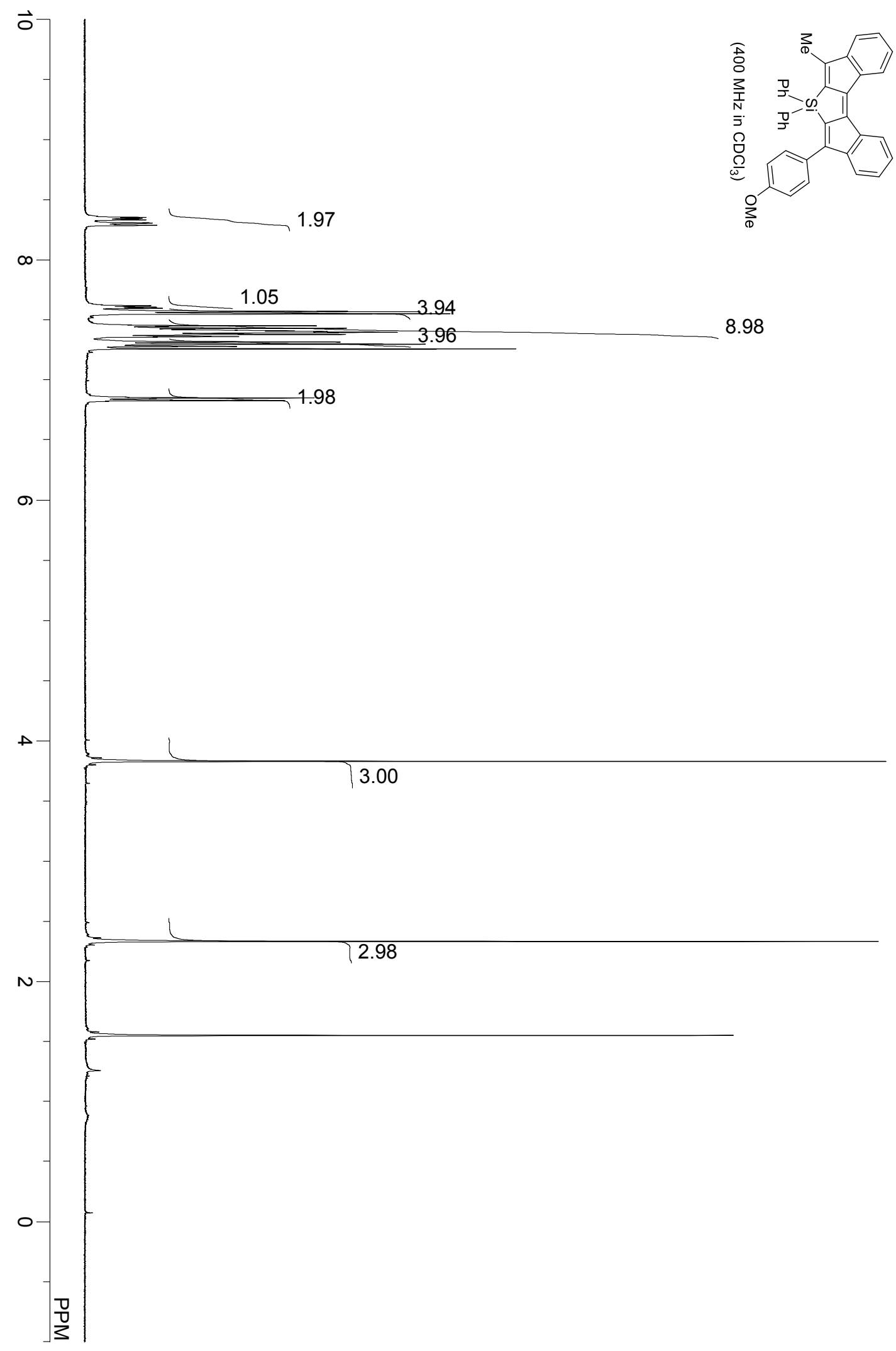


compound 3e

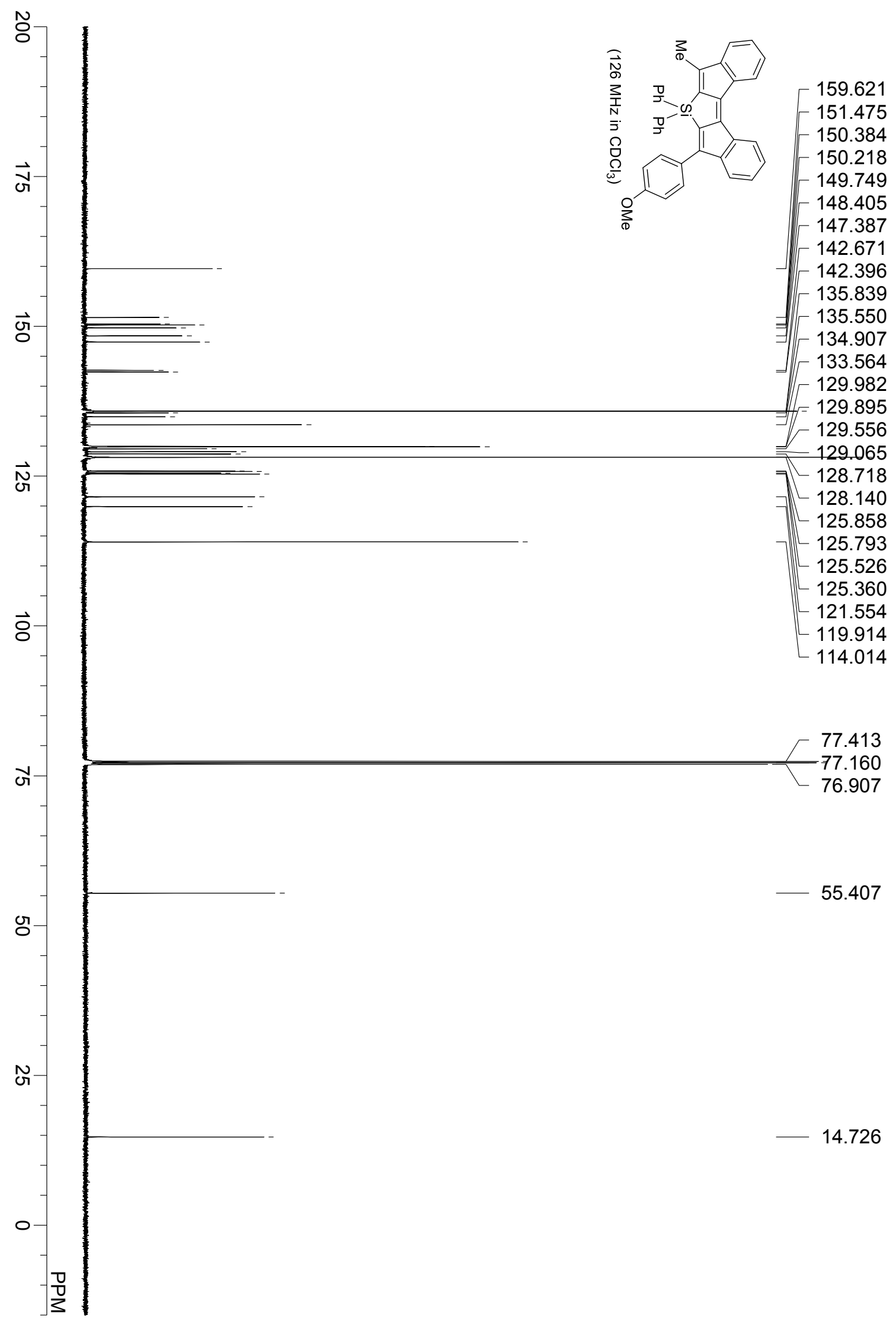


compound $\mathbf{3 f}$

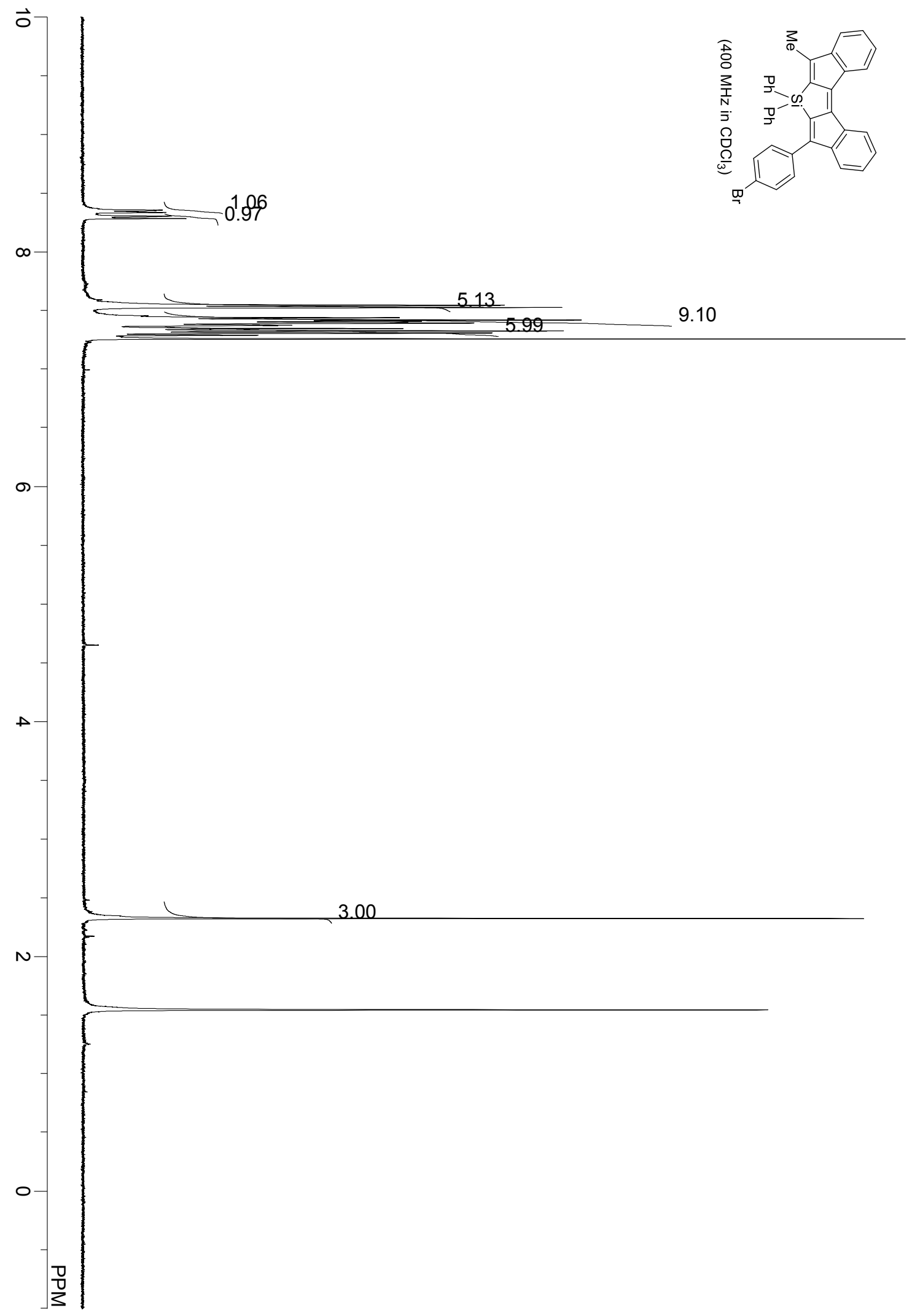


compound $\mathbf{3 f}$

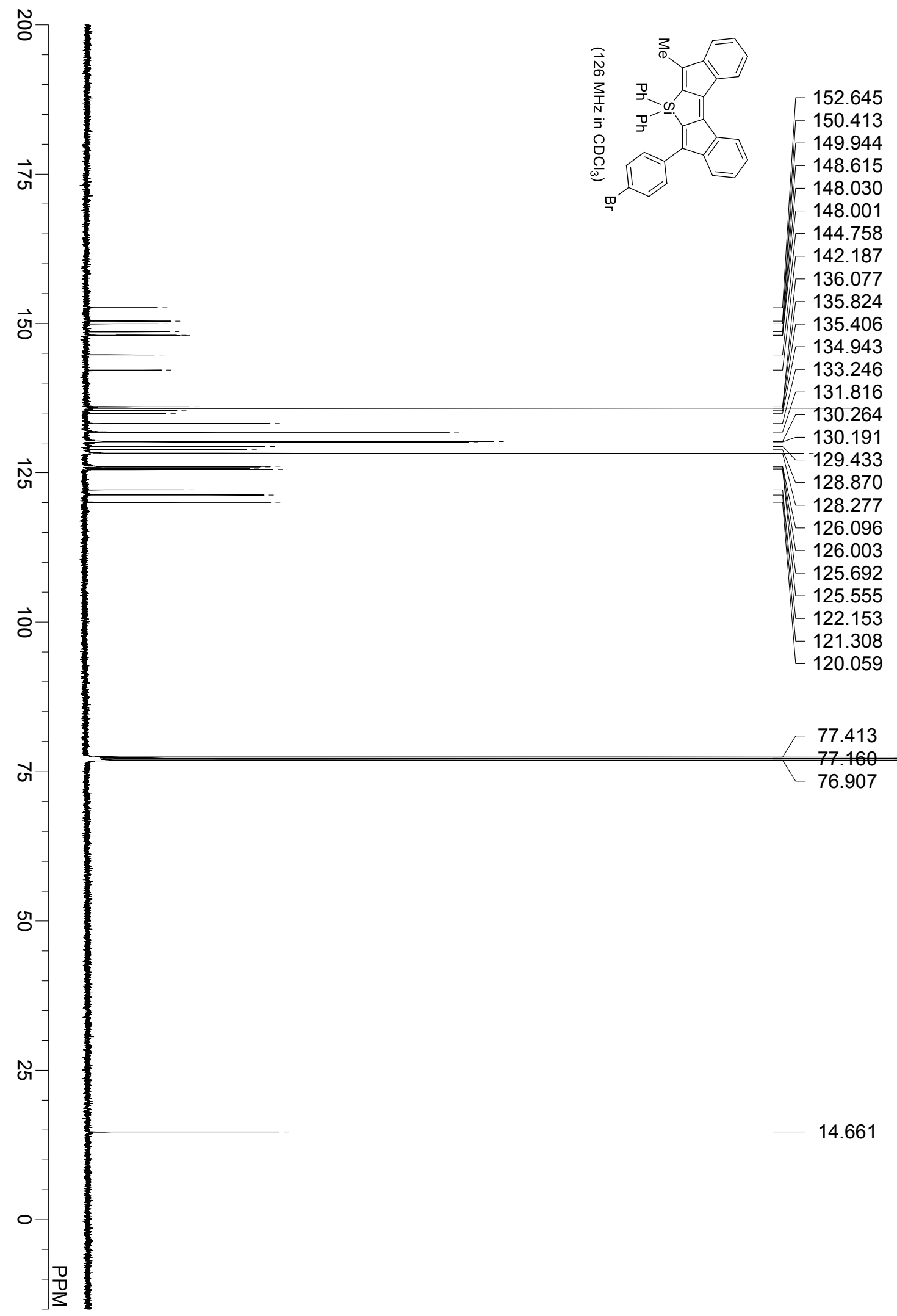


compound $\mathbf{3 g}$

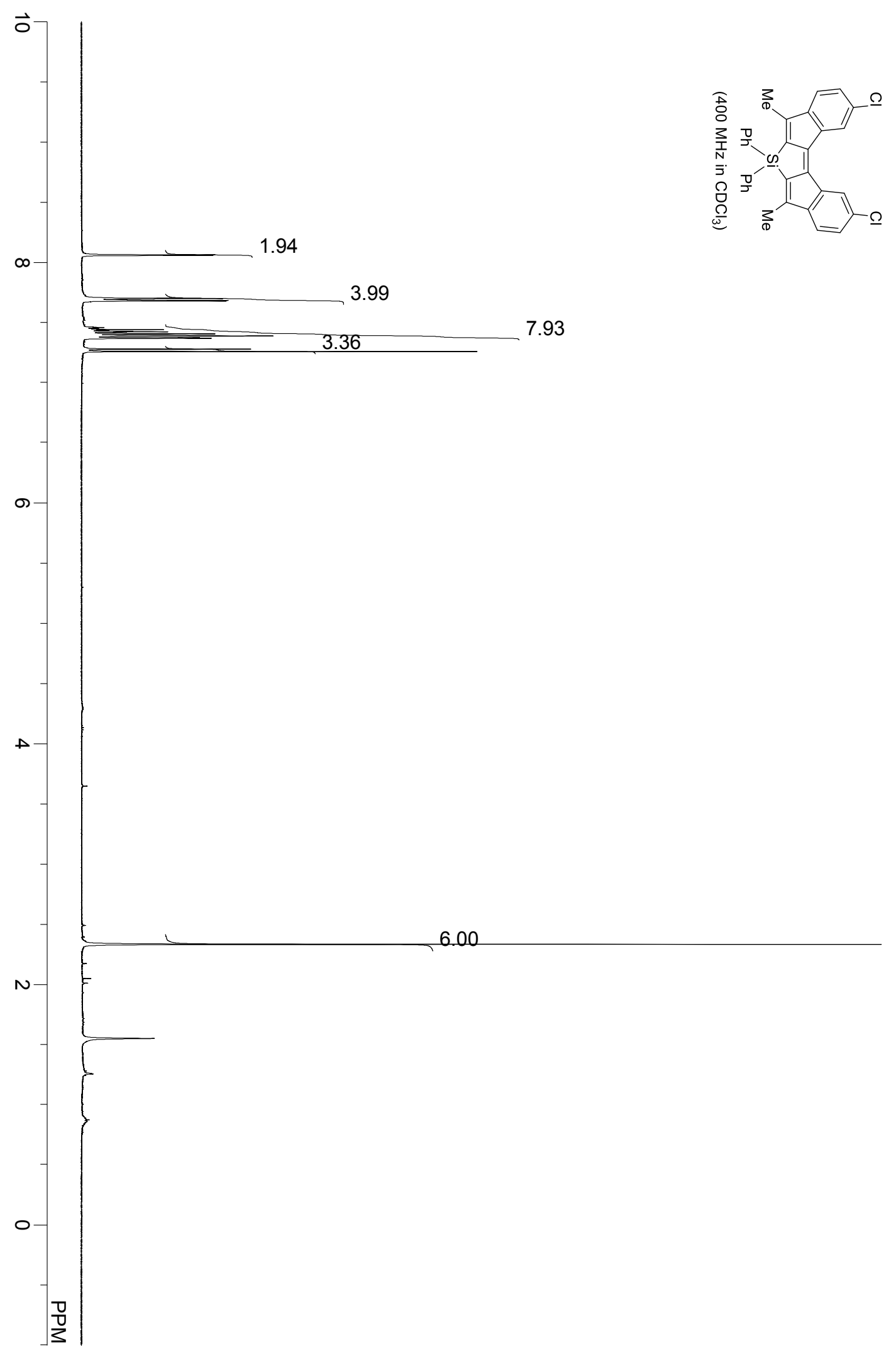


compound 3g

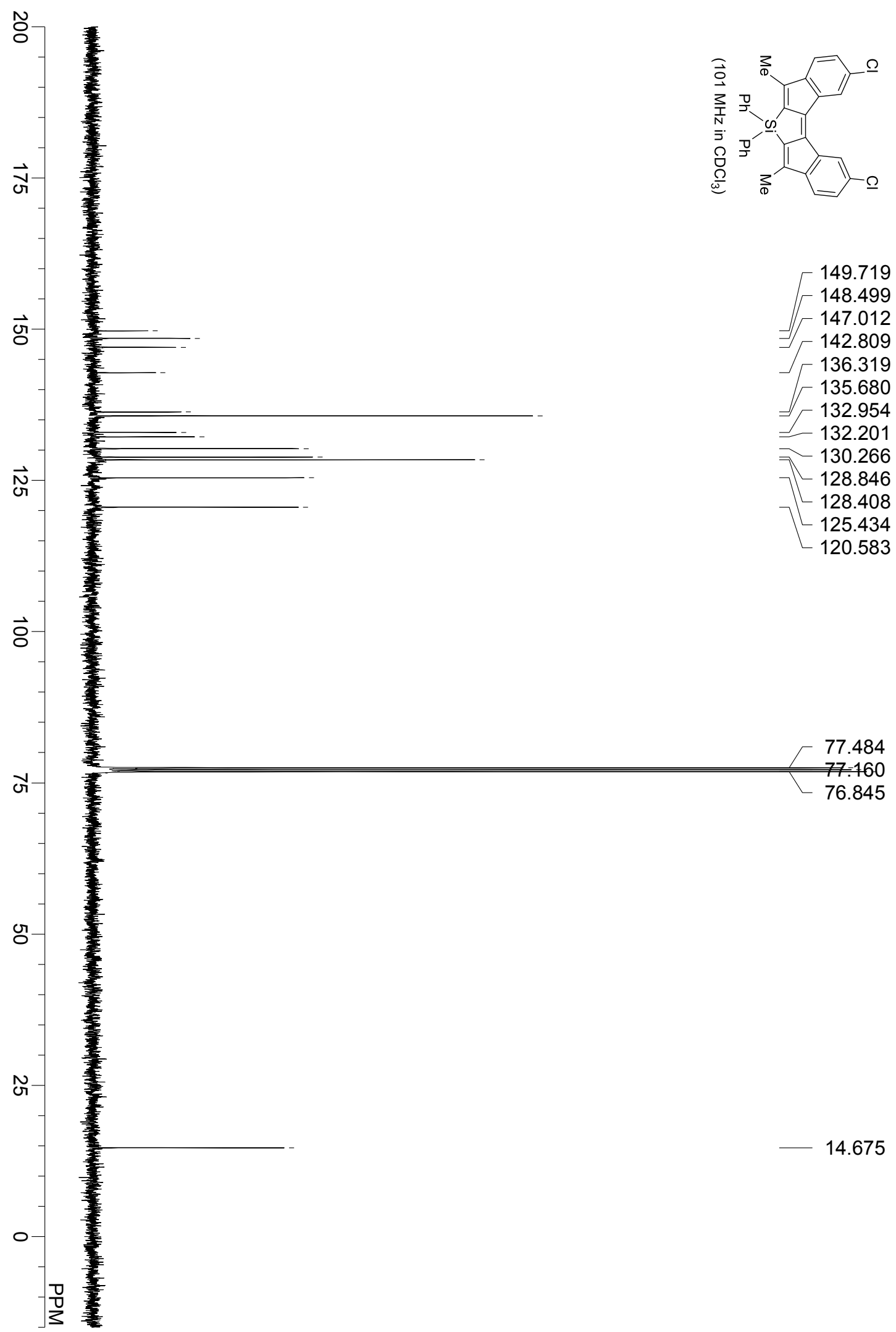


compound 4

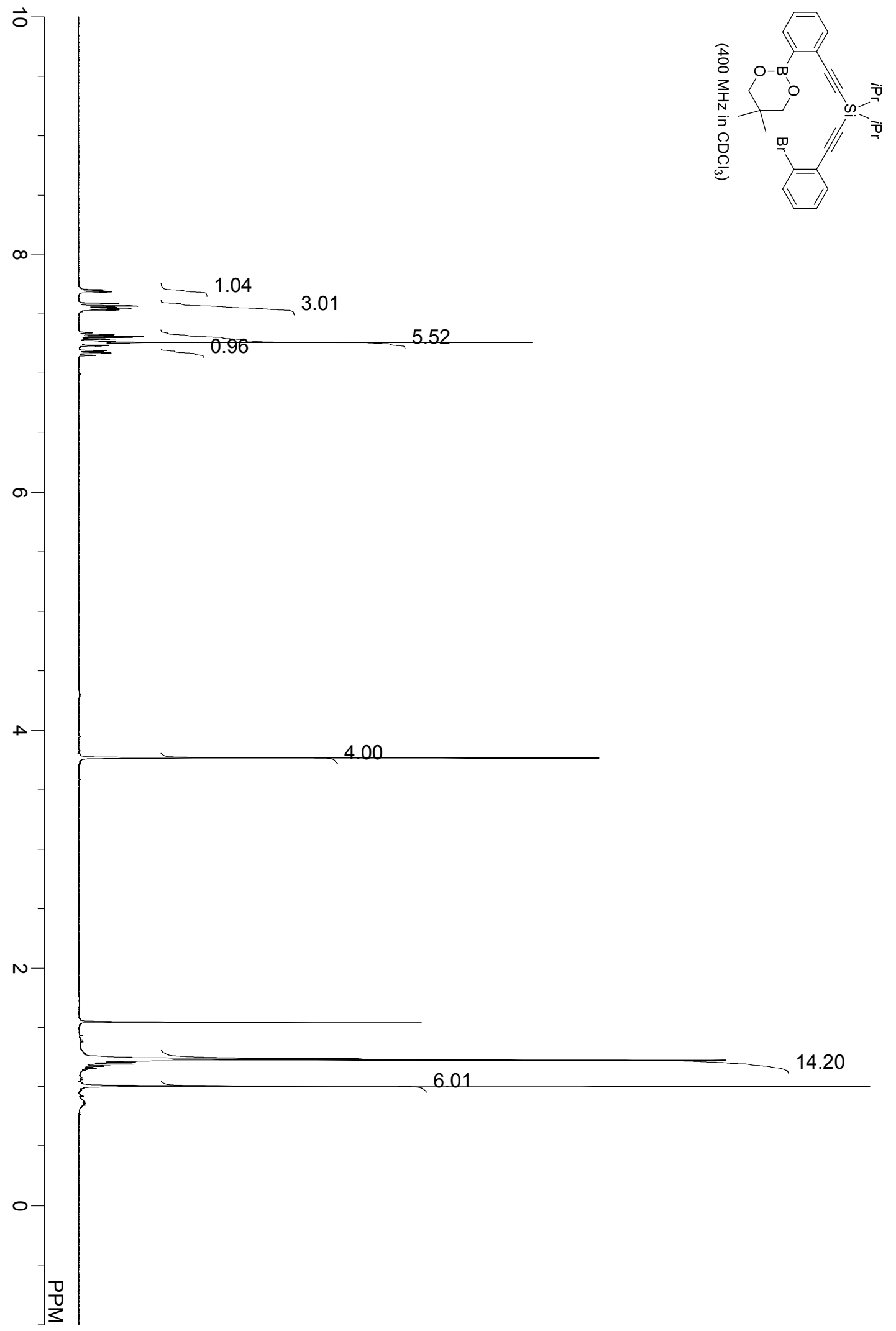


compound 4

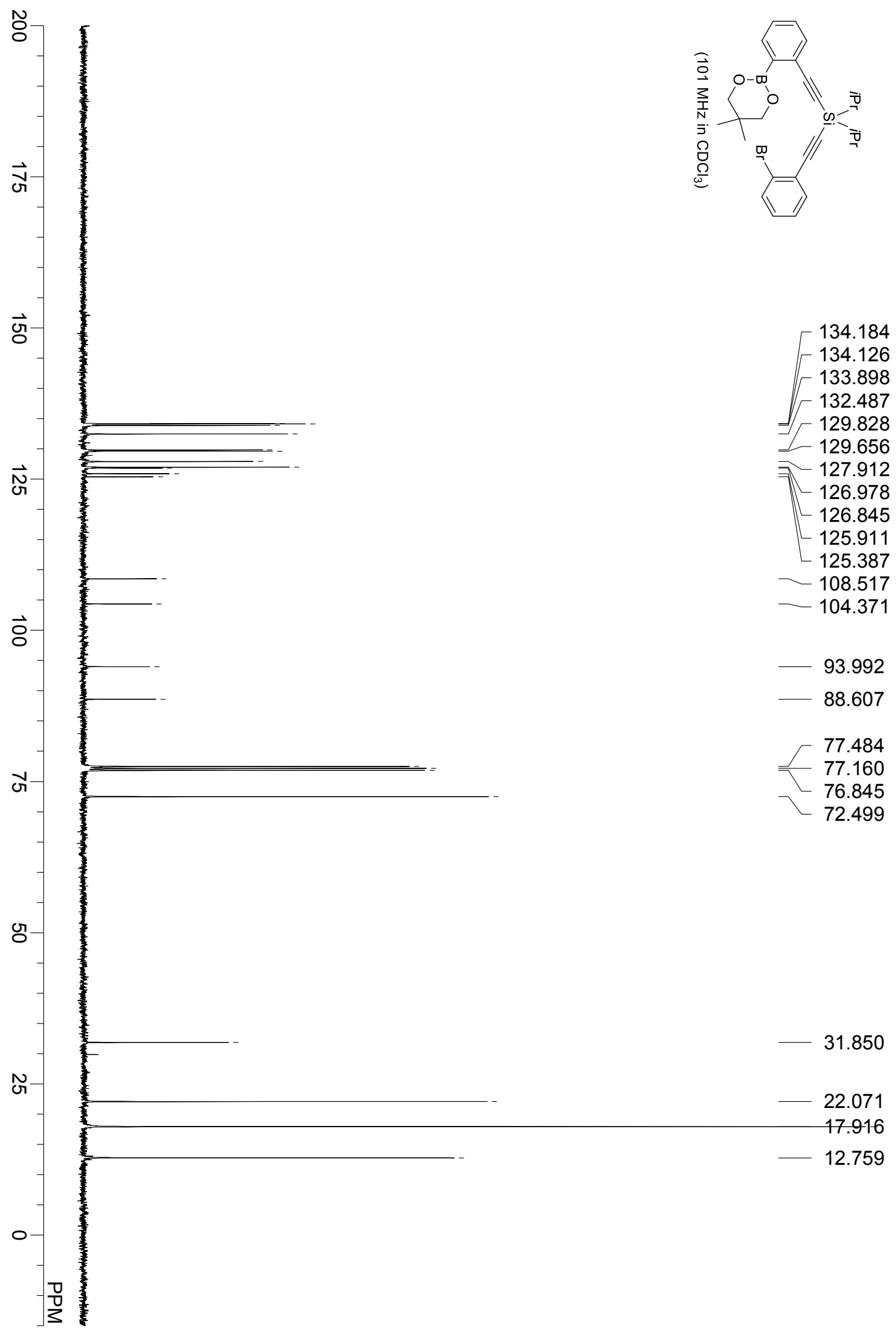


compound $\mathbf{5}$

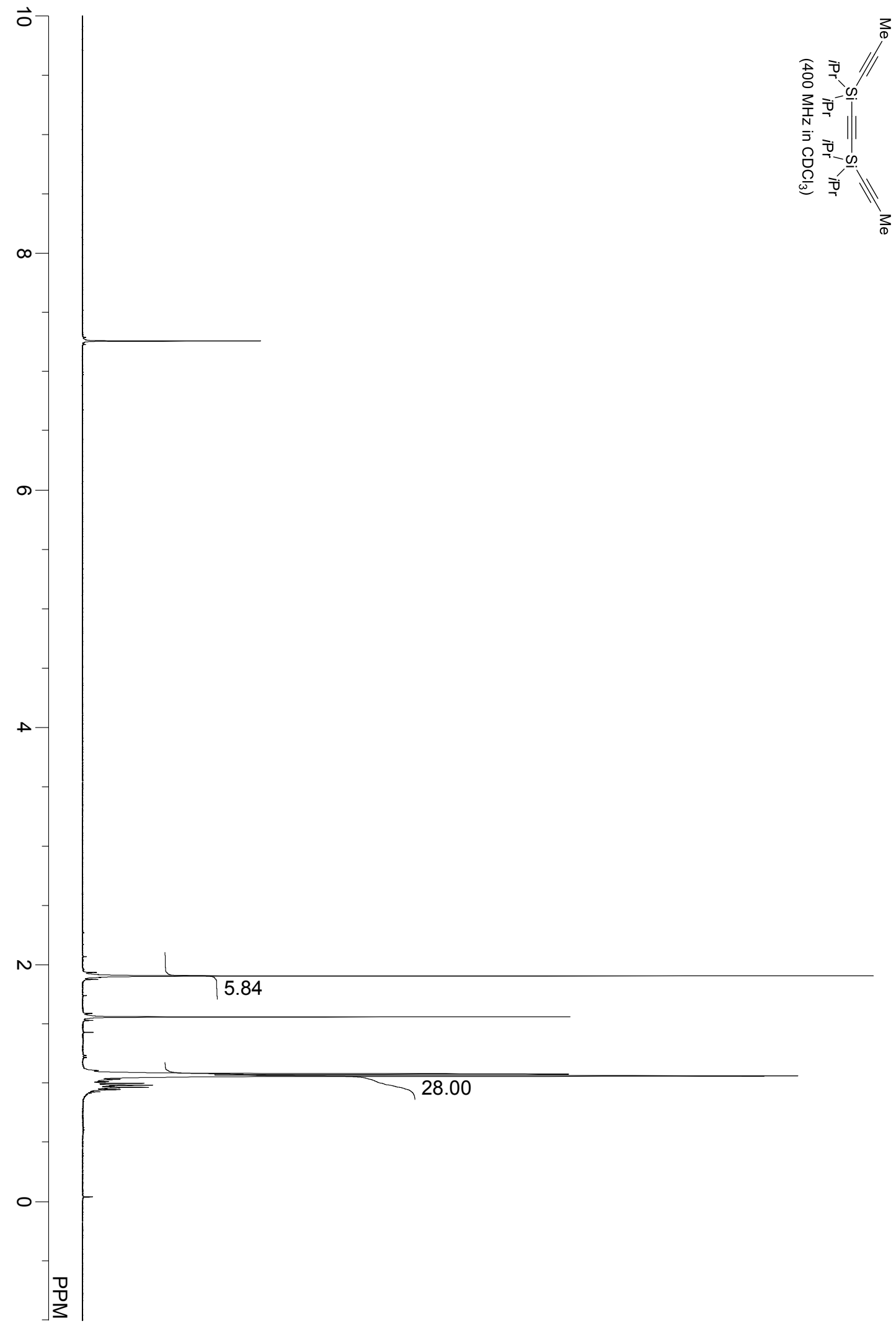


compound $\mathbf{5}$

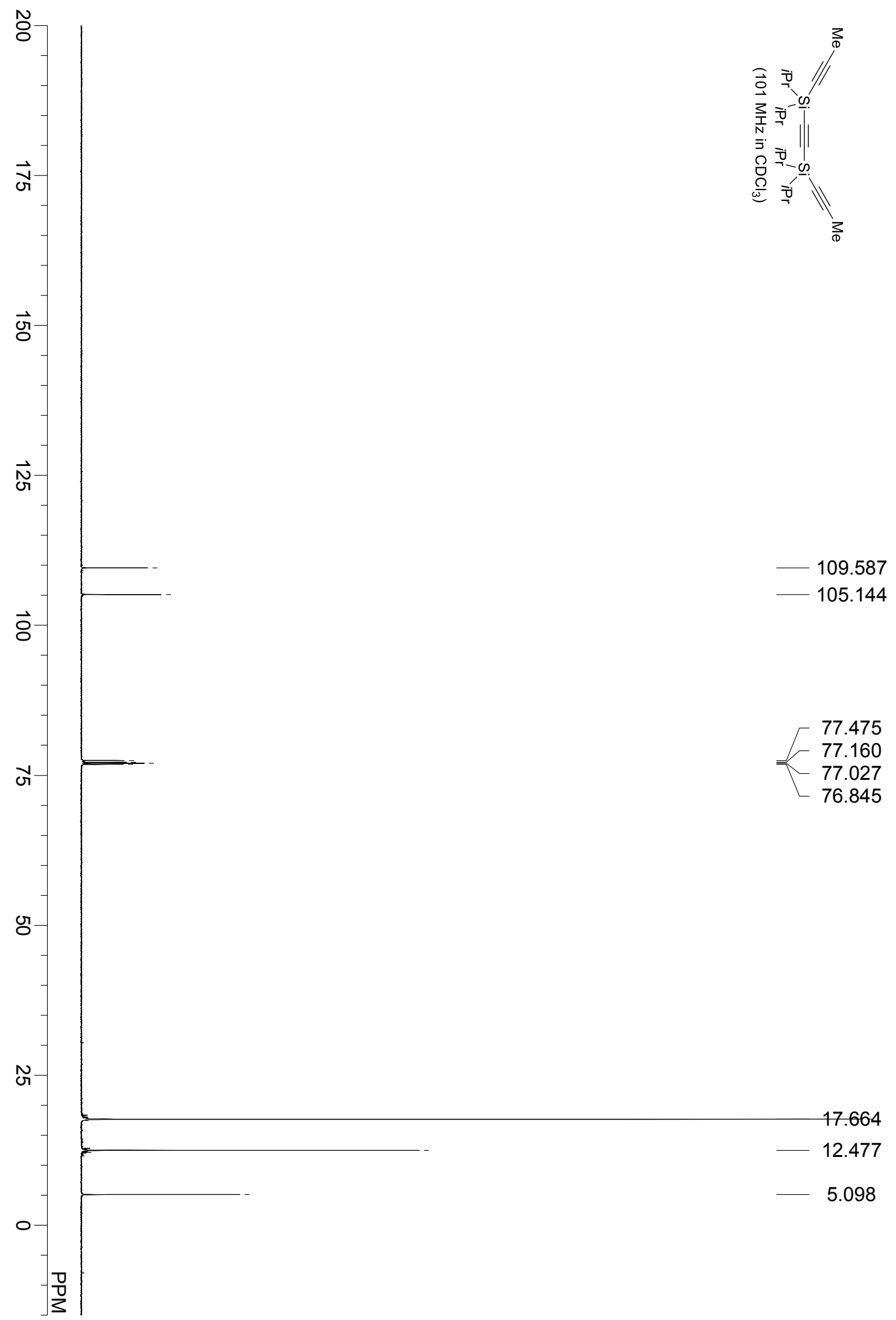


compound $\mathbf{6}$

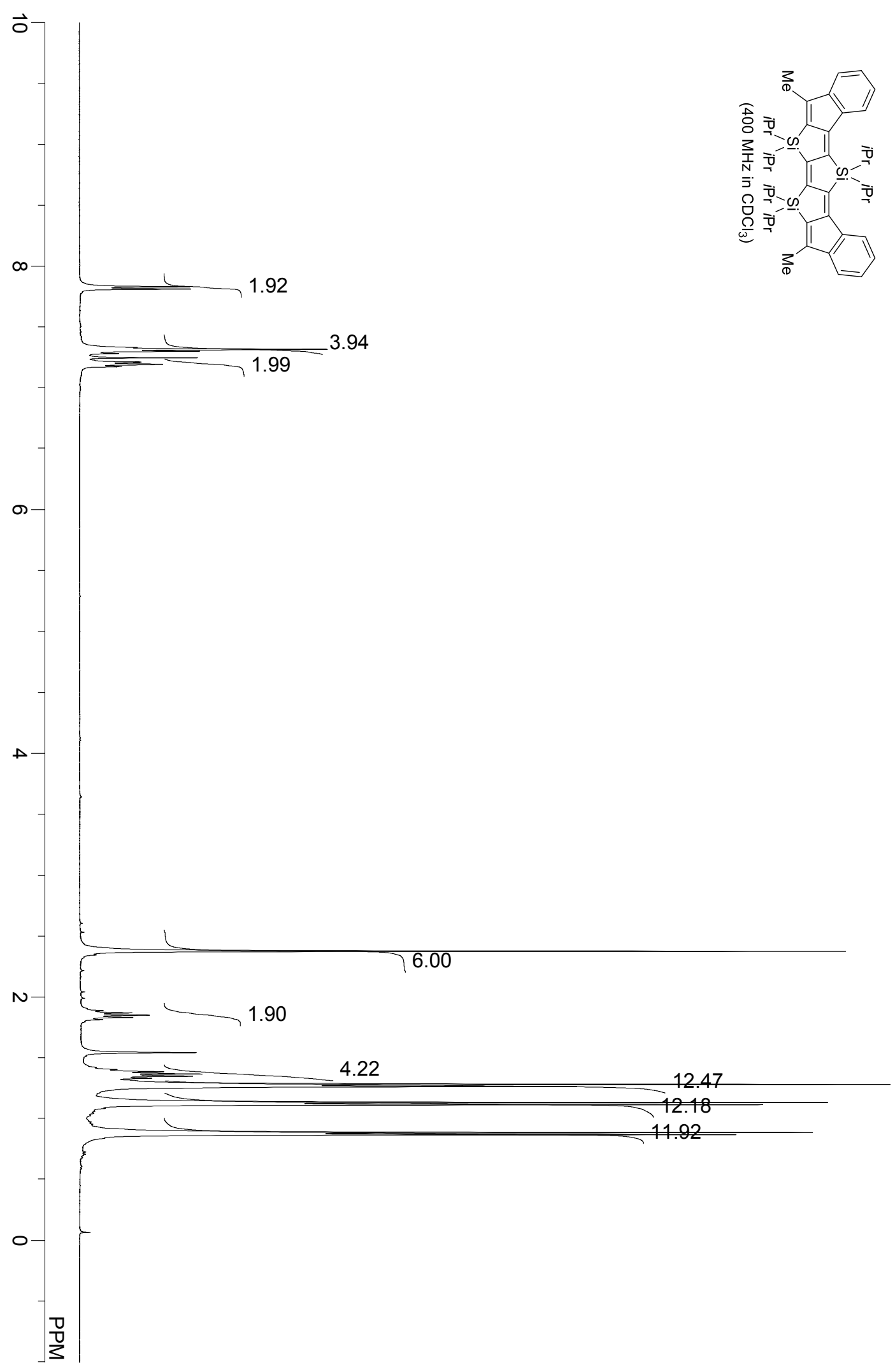


compound $\mathbf{6}$

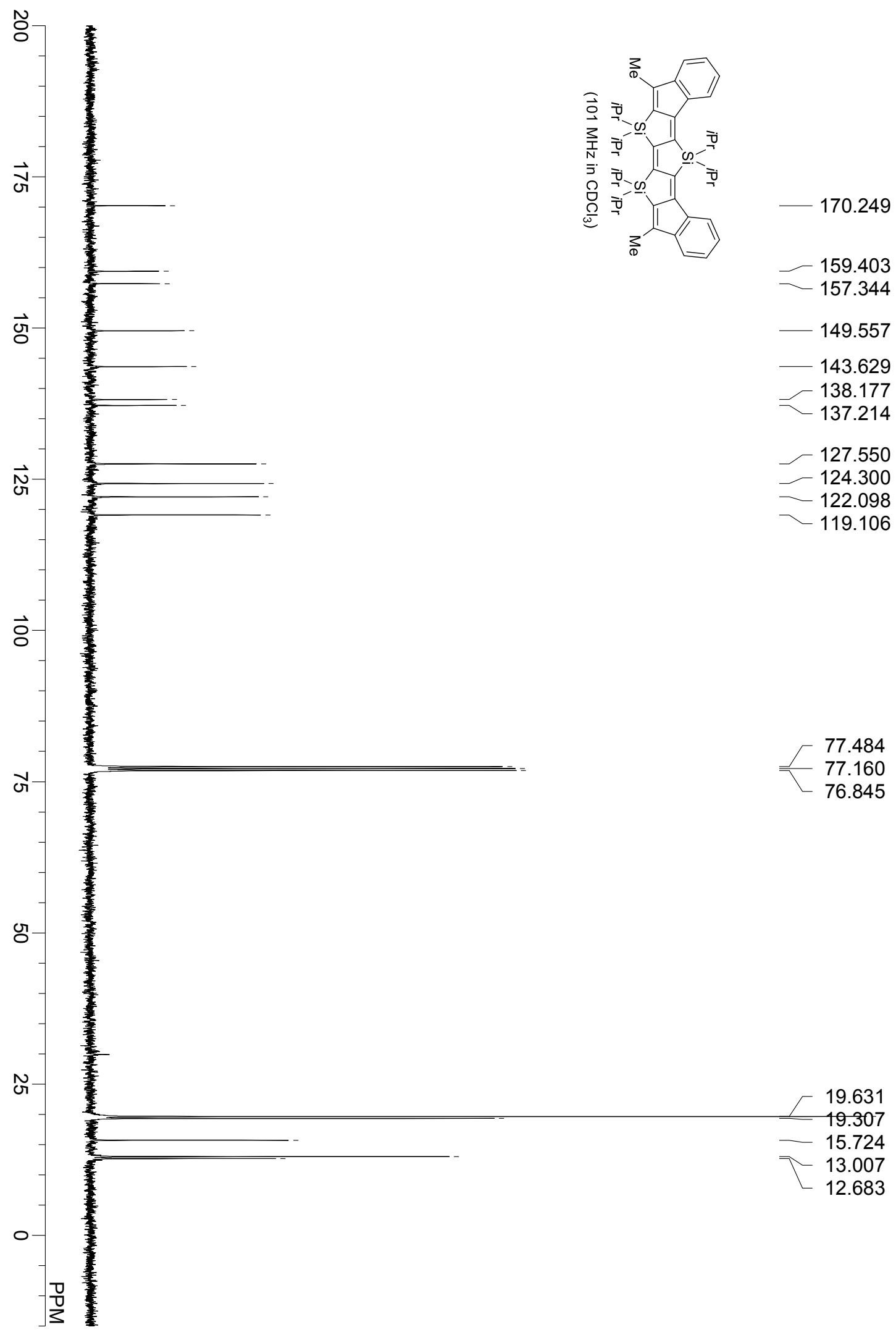


compound 7

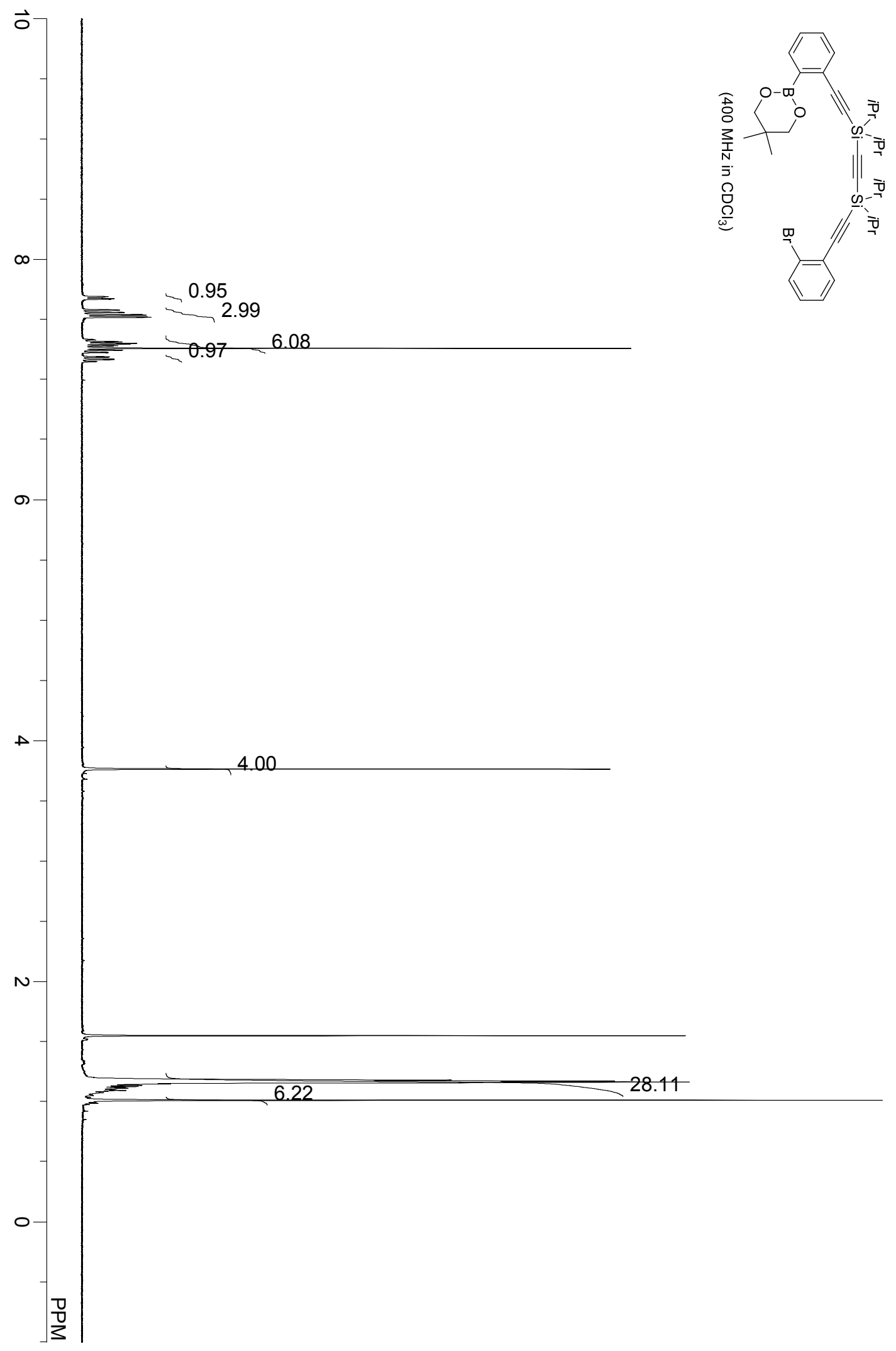


compound 7

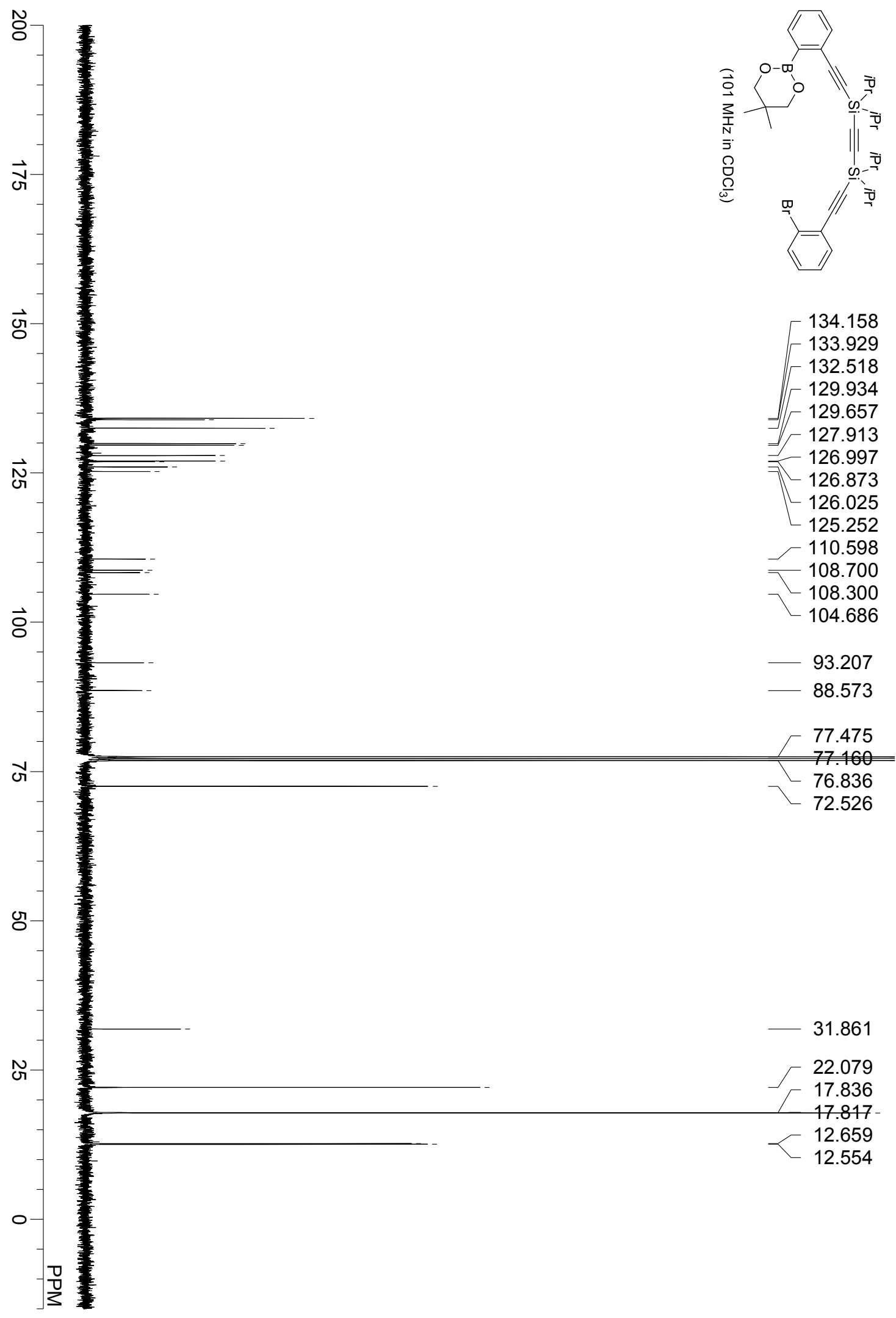


compound $\mathbf{8}$

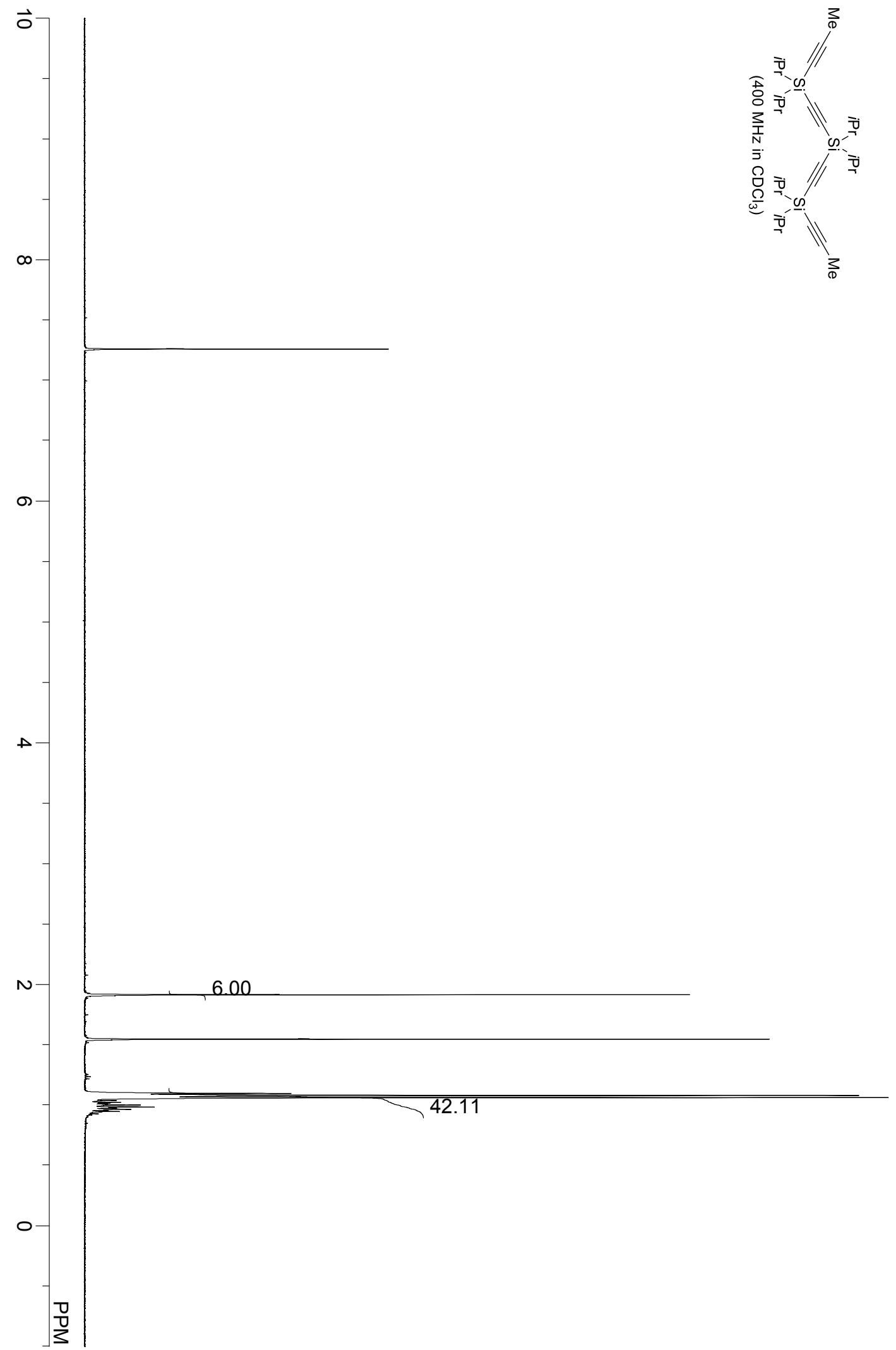


compound $\mathbf{8}$

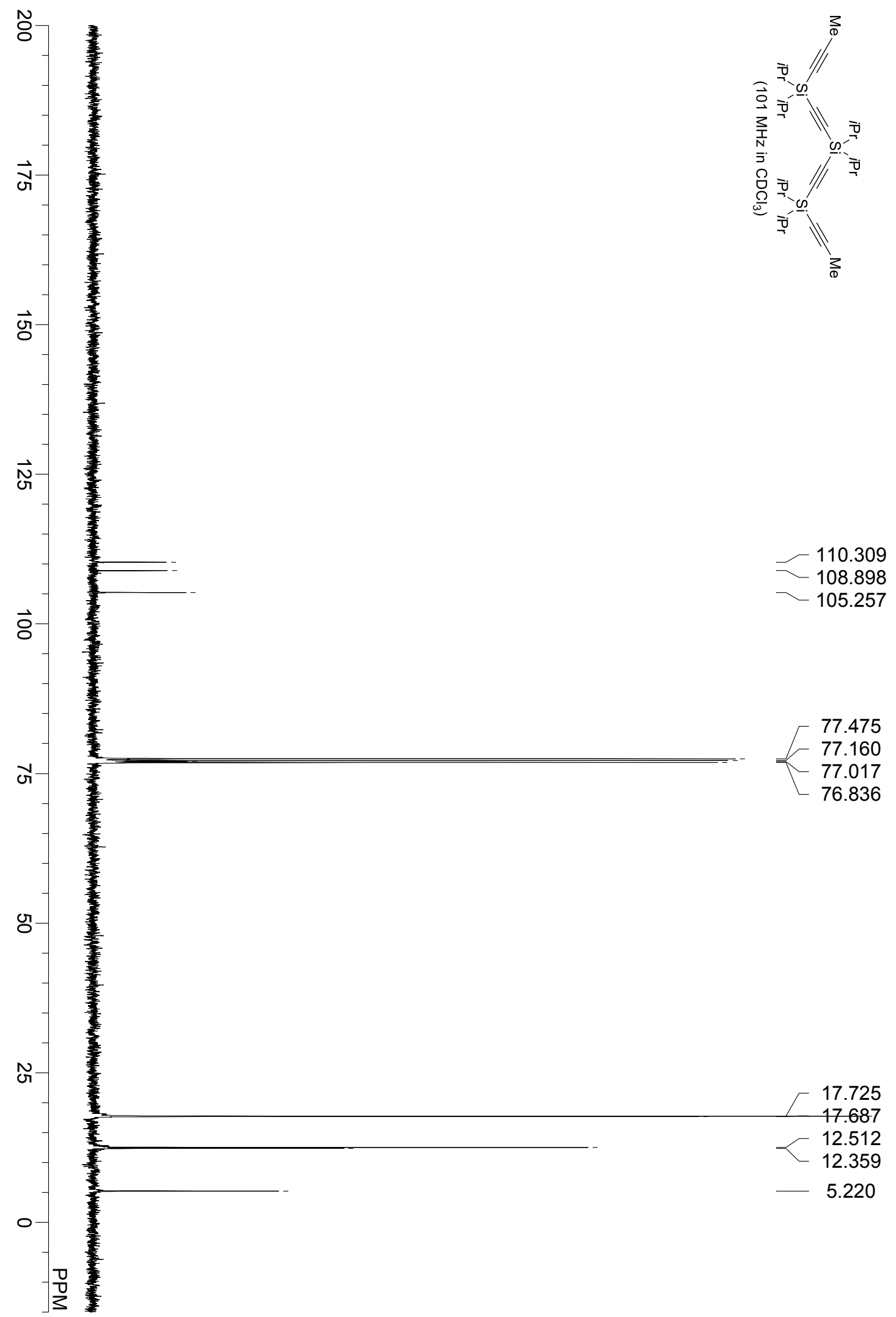


compound 9

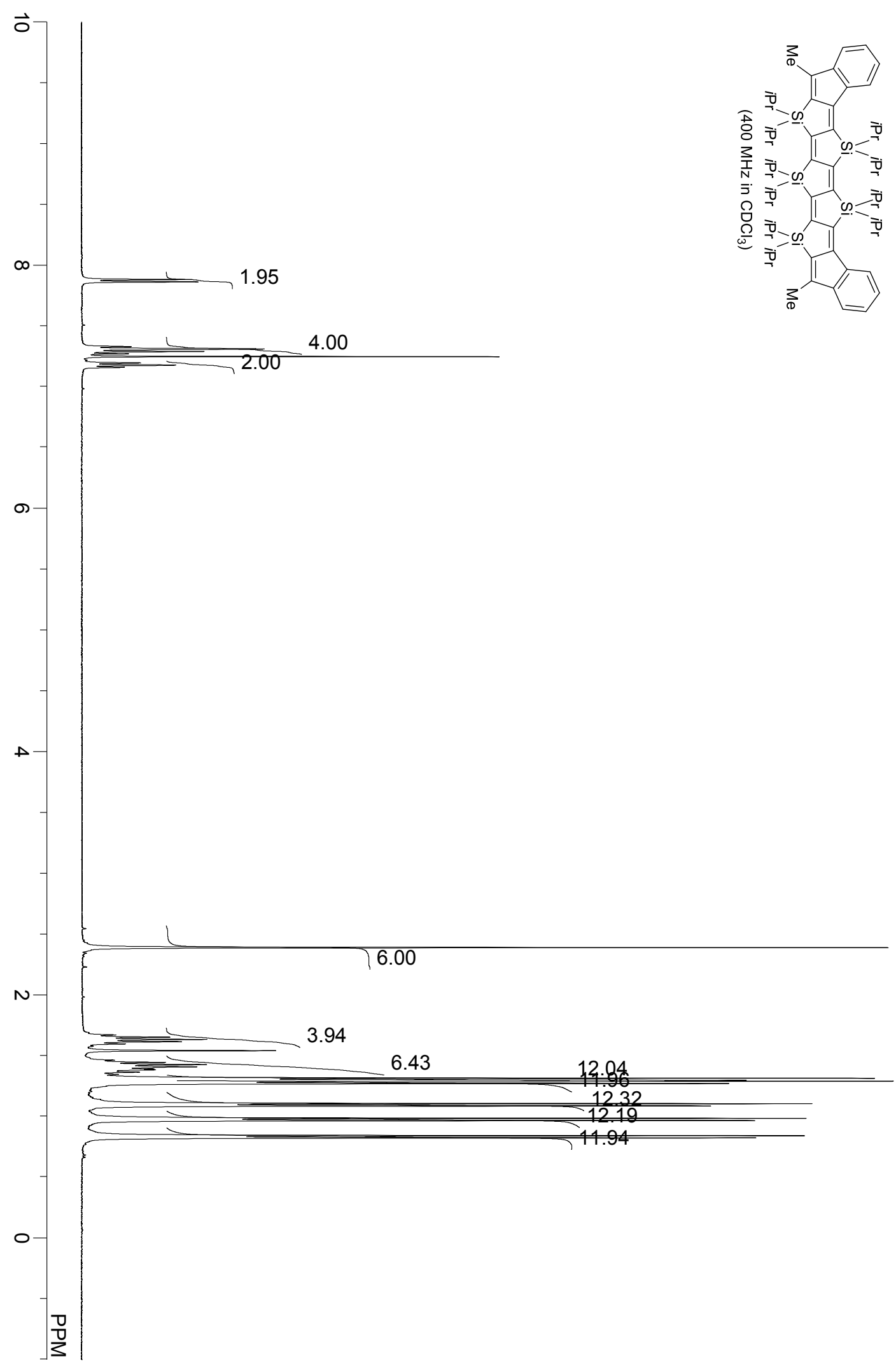


compound 9

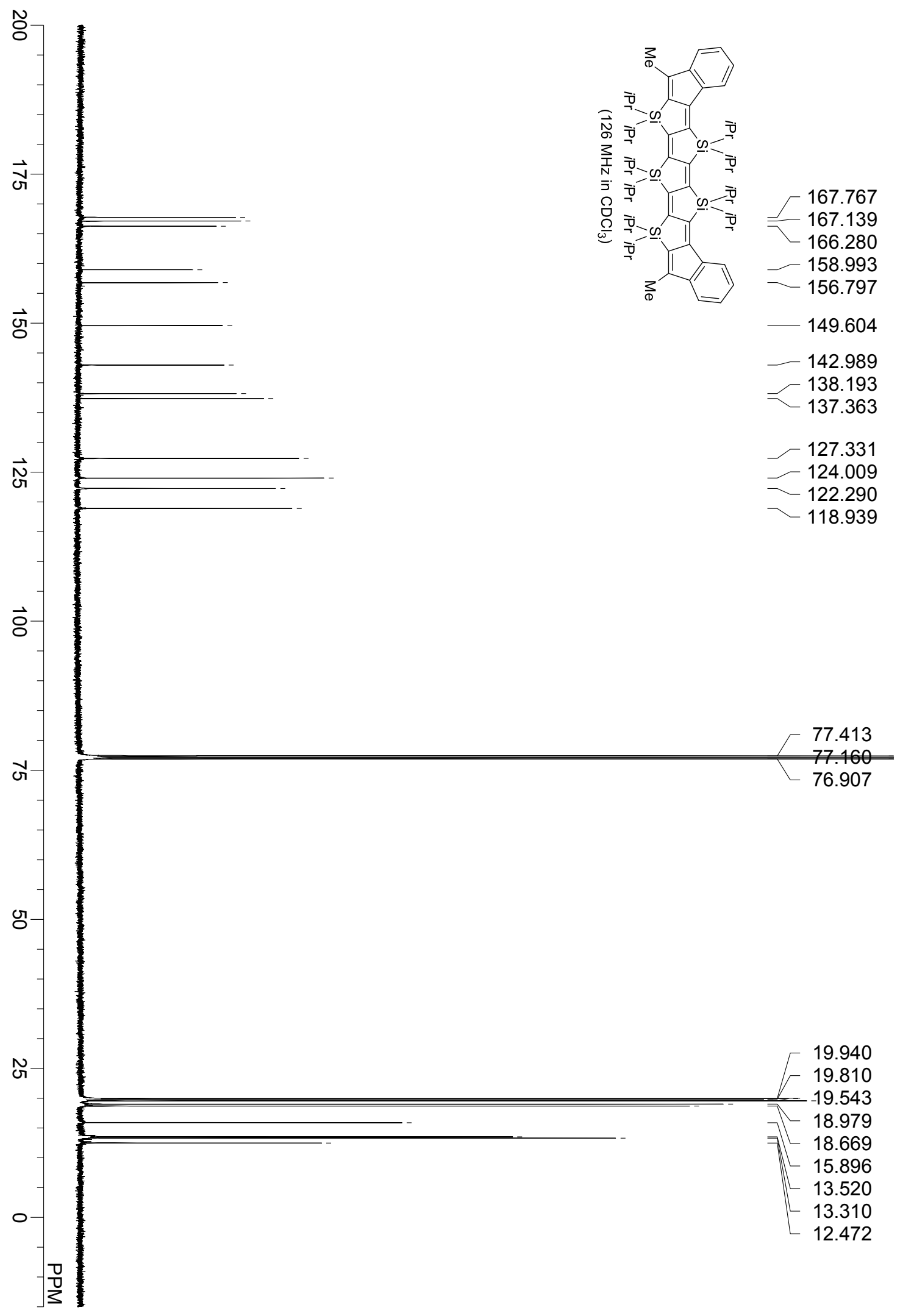

